This is an accepted manuscript of an article published by Taylor \& Francis in Catalysis Reviews on 16 Nov 2020, available online: https://doi.org/10.1080/01614940.2020.1831756

\title{
Progress in the synthesis and applications of hexaaluminate-based
}

\section{catalysts}

\author{
J.J. Torrez-Herrera, S.A. Korili, A. Gil
}

INAMAT^2-Departamento de Ciencias, Edificio de los Acebos, Universidad Pública de Navarra, Campus de Arrosadía E-31006 Pamplona, Spain.

Email: andoni@unavarra.es

\begin{abstract}
The development of materials that can exhibit thermal resistance at very high temperatures, thus allowing them to be applied as catalysts and thermal insulators, amongst other possible uses, is a research subject of great interest. This is the case for hexaaluminates, a class of hexagonal aluminate compounds with a unique structure that are stable at very high temperatures up to $1600{ }^{\circ} \mathrm{C}$ and exhibit exceptional resistance to sintering and thermal shock, thus making them attractive catalysts for high-temperature applications. In this review, the structure of hexaaluminates is presented first. The most recent advances in synthetic methods (sol-gel, reverse microemulsion, hydrothermal synthesis, carbontemplating, solution combustion synthesis and freeze drying methods) are discussed subsequently, with the aim of maximizing textural properties and including in their structure metals known to be active in catalytic applications, such as combustion of $\mathrm{CH}_{4}$, partial oxidation and dry reforming of $\mathrm{CH}_{4}$ to produce synthetic gas, and the decomposition of $\mathrm{N}_{2} \mathrm{O}$. Finally, other applications, such as their function as a thermal barrier, are also addressed.
\end{abstract}


Keywords: hexaaluminate, magnetoplumbite, hibonite, catalytic high-temperature applications, synthesis methods 


\section{Introduction}

Hexaaluminates are a family of hexagonal aluminate compounds with the general formula $A B_{x} A_{12-x} O_{19}$, where $A$ is typically a large cation, for example $\mathrm{Ba}$, La or $\mathrm{Na}$. Component $\mathrm{B}$ is a transition (Co, $\mathrm{Cu}, \mathrm{Fe}, \mathrm{Mn}, \mathrm{Ni}$, etc.) or noble metal (Ir, Pd, Rh, $\mathrm{Ru}$, etc.), which can partially or completely substitute Al crystallographic sites (see Figure 1). ${ }^{[1]}$ The presence of these metals allows the creation or destruction of cationic defects in the structure and, therefore, the generation of possible active centers for catalytic processes with high thermal stability due to the unique crystal structure of these systems. These materials exhibit a stable phase composition up to $1600^{\circ} \mathrm{C}$ and exceptional resistance to sintering and thermal shock, which makes them attractive materials for several applications as ceramics, matrices for immobilization of radioactive elements, catalysts for high-temperature applications, superionic conductors, and luminescent and laser materials, among others. ${ }^{[2-9]}$

The textural properties of these materials are poor, with specific surface areas in the range of 10 to $20 \mathrm{~m}^{2} / \mathrm{g}$, as confirmed from the crystal structures for example (see below). Important efforts have been made over the last few years to enhance these textural properties using non-conventional drying methods. These methods mainly involve decreasing the crystallization temperature, by improving the chemical homogeneity of the precursors, and suppressing grain growth during the crystallization, amongst others. Conservation of the environment by using green processes is another aspect that must be taken into account when developing these synthetic methods.

In addition to enhancing the textural properties of these materials, efforts have also been made to enhance the accessibility of the metal phases in the catalytic processes in which these systems are to be applied. These metal phases can easily be incorporated into the hexaaluminate structure or on the surface of the material, for example by impregnation. 
Metals present in the structure will have limited access to the reagents, as well as a low possibility of acting as redox centers, whereas in the case of metals incorporated on the surface, it will be necessary to increase their dispersion, thus meaning that an enhancement of the textural properties of the support can be considered to be crucial.

This review article covers recent developments in the structure, synthetic methods, and catalytic applications of hexaaluminates. In the case of structure, particular attention is paid to $\beta-\mathrm{Al}_{2} \mathrm{O}_{3}$ and magnetoplumbite (MP) and the mechanism by which defects and surface properties are generated. Typical synthetic methods for hexaaluminates are introduced and discussed, with special emphasis on those that enhance the textural properties. Applications of these materials as catalysts in the combustion of $\mathrm{CH}_{4}$, partial oxidation and reforming of $\mathrm{CO}_{2}$ from $\mathrm{CH}_{4}$ to synthesis gas, as well as the decomposition of $\mathrm{N}_{2} \mathrm{O}$, are also presented. Other applications of these materials, such as their function as a thermal barrier, are also considered. At the end of the review, the main conclusions and perspectives regarding some of the main scientific challenges remaining in the field of hexaaluminates are also analyzed.

\section{Preparation methods for hexaaluminates}

The crystal structure of hexaaluminates was first reported in $1958^{[10]}$ for the compound $\mathrm{LaAl}_{12} \mathrm{O}_{19}$, and the first catalytic study with hexaaluminates was published by Machida et al. in 1987.[11] These authors found that mixing $\mathrm{BaO}$ with $\mathrm{Al}_{2} \mathrm{O}_{3}$ in the composition $(\mathrm{BaO})_{0.14}\left(\mathrm{Al}_{2} \mathrm{O}_{3}\right)_{0.86}$ and calcination at a temperature of $1200{ }^{\circ} \mathrm{C}$ gave the barium hexaaluminate $\left(\mathrm{BaO} \cdot 6 \cdot \mathrm{Al}_{2} \mathrm{O}_{3}\right)$. As their structure is maintained under high-temperature conditions and they can present active metal phases, these materials were reported as the most promising catalytic materials for high-temperature applications. 
Hexaaluminates have unique layered structures consisting of alternatively stacked spinel blocks of closed packed oxide ions and mirror planes (see Figure 1). The spinel blocks are composed only of $\mathrm{Al}^{3+}$ and $\mathrm{O}^{2-}$ ions. Large cations, such as $\mathrm{Na}^{+}, \mathrm{K}^{+}, \mathrm{Sr}^{2+}$ and $\mathrm{La}^{3+}$ for example, can be included in the spacious mirror plane. Considering the charge and radius of the large cations in the mirror plane, hexaaluminates have the structure $\beta-\mathrm{Al}_{2} \mathrm{O}_{3}$ or magnetoplumbite (MP). ${ }^{[13-15]}$ The difference between these two phases lies in the number of $\mathrm{O}^{2-}$ ions in the mirror plane (one or three, respectively). Iyi el al. ${ }^{[16,17]}$ studied the effect of cationic radius on the hexaaluminate structure and found that the upper limit of this radius for the MP type is $0.133 \mathrm{~nm}$. The charge of the ion is also important, and the effect of charge and radius on the hexaaluminate structure is summarized in Figure 2 . In particular, hexaaluminates of the $\mathrm{MAl}_{12} \mathrm{O}_{19}$ type containing ions such as $\mathrm{Ba}^{2+}, \mathrm{Ca}^{2+}, \mathrm{Sr}^{2+}$ or $\mathrm{La}^{3+}$ usually have a magnetoplumbite-type structure, whereas their counterparts containing monovalent ions such as $\mathrm{Na}^{+}, \mathrm{K}^{+}$or $\mathrm{Rb}^{2+}$ exhibit a $\beta-\mathrm{Al}_{2} \mathrm{O}_{3}$ structure.

The structures of $\beta-\mathrm{Al}_{2} \mathrm{O}_{3}$ and $\mathrm{MP}$ can ideally be represented as $\mathrm{MAl}_{11} \mathrm{O}_{17}$ and $\mathrm{MAl}{ }_{12} \mathrm{O}_{19}$, respectively, where $\mathrm{M}$ is a large cation. However, these stoichiometric formulae are only found for a limited number of compounds, such as $\mathrm{CaAl}_{12} \mathrm{O}_{19}$ and $\mathrm{SrAl}_{12} \mathrm{O}_{19}$, because the defect mechanism in the hexaaluminate structure is important. Indeed, non-stoichiometric compositions are observed for almost all $\beta-\mathrm{Al}_{2} \mathrm{O}_{3}$ and trivalent La MP compounds. To explain the hexaaluminate structures, a complex Frenkel defect has been proposed by various authors. ${ }^{[15,18]}$ Without going into too much detail to explain the crystal structure, the formula for the barium-containing $\beta-\mathrm{Al}_{2} \mathrm{O}_{3}$ is $\mathrm{Ba}_{0.75} \mathrm{Al}_{11} \mathrm{O}_{17.25}$. Similarly, the formula for the lanthanum-containing MP is $\mathrm{La}_{0.83} \mathrm{Al}_{11.88} \mathrm{O}_{19.0}$. Zhu et al. ${ }^{[19]}$ have given a clear picture of the evolution of $\mathrm{Fe}$ crystallographic sites in $\mathrm{BaFe}_{x} \mathrm{Al}_{12-\mathrm{x}} \mathrm{O}_{19}$, proposing that the transformation from $\beta_{1}-\mathrm{Al}_{2} \mathrm{O}_{3}$ to MP is the key factor for the stabilization of Fe ions in the hexaaluminate 
structure at high substitution levels. Thus, when $x=1$, the sample only crystallized in the $\beta$ $\mathrm{Al}_{2} \mathrm{O}_{3}$ phase, whereas when increasing $x$ up to $2-4$, some of the $\mathrm{Fe}^{3+}$ ions started to enter into the MP phase in addition to the $\beta-\mathrm{Al}_{2} \mathrm{O}_{3}$ phase. At $\mathrm{x}>5$, the site occupancy of Fe in the MP phase started to increase continuously, finally forming $\mathrm{BaFe}_{12} \mathrm{O}_{19}$ at $\mathrm{x}=12$ (see Figure 3). A similar study was carried out with the hexaaluminate $\mathrm{LaFe}_{x} \mathrm{Al}_{12-\mathrm{x}} \mathrm{O}_{19}{ }^{[20]}$

As the hexaaluminate structure is formed at high calcination temperatures, the textural properties exhibited by these materials are poor. Thus, it has been reported that, after calcination at $1200{ }^{\circ} \mathrm{C}$, the specific surface areas of these materials is only about 20 $\mathrm{m}^{2} / \mathrm{g}$, decreasing for higher calcination temperatures. As such, numerous efforts have been made to increase the specific surface areas and pore volumes of these materials by developing more efficient synthetic routes. In this regard, sol-gel, co-precipitation and reverse microemulsion methods, among others, have been reported. ${ }^{[21]}$

Hexaaluminates can also be synthesized via a solid state reaction involving calcination of the metal oxide and carbonate as starting materials to promote solid state diffusion. However, as solid state diffusion is slow, high reaction temperatures (usually above $1300^{\circ} \mathrm{C}$ ) and long reaction times are required to complete the reaction and obtain a pure hexaaluminate phase. Thus, for example, Machida et al. ${ }^{[11]}$ calcined a mixture of $\mathrm{BaCO}_{3}$ and $\gamma-\mathrm{Al}_{2} \mathrm{O}_{3}$ at $1450{ }^{\circ} \mathrm{C}$ to obtain a pure $\beta-\mathrm{Al}_{2} \mathrm{O}_{3}$ phase with a specific surface area of $6 \mathrm{~m}^{2} / \mathrm{g}$. These authors observed that $\mathrm{BaAl}_{2} \mathrm{O}_{4}$ is produced initially at $1000{ }^{\circ} \mathrm{C}$ from the reaction between $\mathrm{BaCO}_{3}$ and $\gamma-\mathrm{Al}_{2} \mathrm{O}_{3}$, followed by a reaction between $\mathrm{BaAl}_{2} \mathrm{O}_{4}$ and $\gamma-\mathrm{Al}_{2} \mathrm{O}_{3}$ to form the hexaaluminate. The synthesis of high purity Ba-hexaaluminates using this procedure was also reported by Chandra. ${ }^{[22]}$ In this case, a powdered mixture of $\mathrm{BaCO}_{3}$ and $\mathrm{BaCl}_{2} \cdot 2 \mathrm{H}_{2} \mathrm{O}$ $(75 / 25 \mathrm{w} / \mathrm{w})$ with aluminum oxide was heated at $1350{ }^{\circ} \mathrm{C}$. Other authors previously performed mechanical activation by grinding as an initial step prior to calcination of the 
precursors. ${ }^{[23,24]}$ This initial step is intended to homogenize the precursors. The study was completed by determining the effect of precursors, grinding, and calcination temperature on the composition and surface area of the synthesized materials. Similarly, Jansen et al. ${ }^{[25]}$ combined $\mathrm{BaCO}_{3}, \mathrm{CaCO}_{3}, \mathrm{SrCO}_{3}, \mathrm{Eu}_{2} \mathrm{O}_{3}, \mathrm{MgCO}_{3}, \mathrm{AIN}$ and $\gamma-\mathrm{Al}_{2} \mathrm{O}_{3}$ in different mixtures to synthesize alkaline-earth hexaaluminates with a $\beta-\mathrm{Al}_{2} \mathrm{O}_{3}$ or an MP-type structure after thermal treatment at $1700{ }^{\circ} \mathrm{C}$ for $2 \mathrm{~h}$. Djambazov and Yoleva ${ }^{[7]}$ reported the synthesis of La ${ }_{1-}$ ${ }_{x} \mathrm{Ca}_{x} \mathrm{Al}_{11-\mathrm{y}-\mathrm{z}} \mathrm{Mg}_{\mathrm{y}} \mathrm{Ti}_{z} \mathrm{O}_{18}$, which they subsequently used as materials for the production of mill bodies and immobilization of nuclear waste.

A solvent-free synthesis starting from metal oxides has been reported by Laassiri et al. ${ }^{[26]}$ This synthetic route involves a combination of two grinding processes, namely highenergy and low-energy ball milling. High-energy ball milling leads to a significant reduction in crystallite size. Although the mean crystallite size is reduced to $20 \mathrm{~nm}$, the resulting material remains highly agglomerated and contains a very high number of grain boundaries. A second milling process at lower energy is therefore performed to deagglomerate the nanostructured material and to form high specific surface areas. $\mathrm{BaAl}_{12} \mathrm{O}_{19}, \mathrm{BaCoAl}_{11} \mathrm{O}_{19}$ and $\mathrm{BaMnPd}_{0.07} \mathrm{Al}_{10.93} \mathrm{O}_{19}$ hexaaluminates with specific surface areas in the range between 77 and $100 \mathrm{~m}^{2} / \mathrm{g}$ were obtained after calcination at $1100^{\circ} \mathrm{C}$. This solid state reaction method is very simple and has been reported to be suitable for large-scale production since it does not involve a very complex and expensive procedure. Its main disadvantage, however, is the lack of homogeneity of the synthesized oxides and, as a consequence, low specific surface area.

Other methods, which have replaced the solid-solid reaction procedure, are based on dissolving the precursors in a liquid medium, followed by reaction, drying and calcination steps. This category includes sol-gel, co-precipitation and reverse microemulsion methods. The use of a liquid medium ensures that a more homogeneous precursor is obtained, thus 
allowing the crystallization temperature to be reduced and, in turn, suppressing grain growth and the loss of textural properties.

The sol-gel method is based on the hydrolysis of precursors such as alkoxides, acetylacetonates, carboxylates, chlorides and nitrates, amongst others, to generate a homogeneous solution and transform it into a gel by densification or subsequent heat treatment. This is one of the methods proposed as being most suitable for obtaining fine particles of high purity oxides. ${ }^{[27]}$ An additional advantage of these methods is that they allow complex oxides to be processed at low temperature due to the homogeneous mixing of components at the molecular level, which means that the textural properties of the oxides synthesized can be improved. In this regard, Machida et al. ${ }^{[11,28-30]}$ synthesized $\mathrm{Ba}$ hexaaluminates using barium isopropoxide and aluminum dissolved in 2-propanol as starting materials, obtaining a pure hexaaluminate phase with a specific surface area of $15 \mathrm{~m}^{2} / \mathrm{g}$ at $1450{ }^{\circ} \mathrm{C}$. These authors found that this hexaaluminate phase is obtained directly from the amorphous precursor without the formation of $\mathrm{BaAl}_{2} \mathrm{O}_{4}$ intermediates due to the homogeneous mixing of $\mathrm{Ba}$ and $\mathrm{Al}$ atoms in the alcoholic solution. They also reported that the hydrolysis of precursors must be completed carefully before drying and calcination to obtain samples with high specific surface areas. The synthesis of $\mathrm{Sr}_{0.8} \mathrm{La}_{0.2} \mathrm{XAl}_{11} \mathrm{O}_{19}(\mathrm{X}=\mathrm{Al}$ and $\mathrm{Mn}$ ) was also reported by the same research group. ${ }^{[31,32]}$ The same procedure, but with the presence of copper nitrate, was used by Artizzu et al. ${ }^{[33]}$ to prepare $\mathrm{BaCuAl}_{11} \mathrm{O}_{18.5}$ with a specific surface area of $11 \mathrm{~m}^{2} / \mathrm{g}$ after calcination at $1200{ }^{\circ} \mathrm{C}$. Substitution of one copper ion for aluminum in the hexaaluminate phase does not induce a severe structural stress, since the structure is preserved. The presence of copper ions at tetrahedral sites in the spinel block was confirmed by the diffuse reflectance spectra of the hexaaluminate. Rezaie et al. ${ }^{[34]}$ also proposed a sol-gel method to obtain Ba-hexaaluminates with a fibrous structure. This 
method is based on the formation of two gels (see Figure 4). Fe-substituted Bahexaaluminates were prepared by Naoufal et al., ${ }^{[35]}$ with Mössbaauer spectroscopy subsequently showing that $\mathrm{Fe}^{3+}$ is present at four different octahedral sites; the substitution of aluminum by iron seems to have no limits. Debsikbar ${ }^{[36]}$ proposed the synthesis of Bahexaaluminates via hydrolysis of Al di(isopropoxide) acetoacetic ester chelate and anhydrous Ba acetate obtained from the reaction between $\mathrm{BaCO}_{3}$ and glacial acetic acid. The aim of the author was to control chemical polymerization during gel formation. The final phase was obtained after calcination at $1200{ }^{\circ} \mathrm{C}$ for $2 \mathrm{~h}$. The synthesis of $\mathrm{CaAl}_{12} \mathrm{O}_{19}$ from calcium and aluminum nitrates mixed with a solution of ammonium citrate, acrylamide and $\mathrm{N}, \mathrm{N}^{\prime}$ methylenediacrylamide has been reported by Douy. ${ }^{[37]}$ The solution was initially heated to boiling temperature and to several other temperatures in a ventilated furnace to obtain the hexaaluminate.

The effect of the precursor solution concentration on the thermal stability of $\mathrm{Sr}_{0.8} \mathrm{La}_{0.2} \mathrm{MnAl}_{11} \mathrm{O}_{19}$ has been investigated by Woo et al. ${ }^{[38]}$ These authors observed that low concentrations allow acceleration of the sintering phenomena, thus resulting in rapid particle growth and a drastic decrease in the specific surface area. Similarly, Yan et al. ${ }^{[39]}$ synthesized hexaaluminates by drying gels produced under supercritical conditions and at room temperature and pressure. These authors used barium ethoxide and aluminum secbutoxide as precursors and ethanol as solvent and found that aerogel-derived hexaaluminates have a higher specific surface area and porosity than their xerogel-derived counterparts, thus appearing to indicate that the drying method significantly affects the properties of the hexaaluminates obtained. The effect of drying method on the composition of the phase has also been investigated by $\mathrm{Xu}$ et al. ${ }^{[40]}$ These authors found that $\alpha-\mathrm{Al}_{2} \mathrm{O}_{3}$ could be detected in the xerogel calcined at $1200{ }^{\circ} \mathrm{C}$ but was absent in the sample obtained 
from the aerogel. As an explanation, the authors proposed that, when drying in a conventional oven, migration of the $\mathrm{Ba}, \mathrm{Mn}, \mathrm{Al}$ species due to the flow of liquid to the surface from the internal pores, driven by the capillary tension gradient, results in a heterogeneous mixture of the components since the solubility of the different $\mathrm{Ba}, \mathrm{Mn}$ and $\mathrm{Al}$ species in water is different. In the case of supercritical drying, migration of the $\mathrm{Ba}, \mathrm{Mn}$ and Al species caused by flow of the liquid is avoided because capillary stress is eliminated, thus meaning that the homogeneity of the mixture of components is maintained. This procedure was used by Inoue et al. ${ }^{[3]}$ to synthesize films coated with ceramic substrates for use in hightemperature combustion applications (see Figure 5). Cho et al. ${ }^{[41]}$ proposed the synthesis of hexaaluminates in the presence of surfactants using a commercial alumina sol and metal acetate precursors, under ambient conditions. These authors observed that the $\mathrm{Al}_{2} \mathrm{O}_{3} /$ surfactant ratio and the presence of organic additives markedly affect the properties of the hexaaluminates obtained. Thus, with an $\mathrm{Al}_{2} \mathrm{O}_{3} /$ cetyltrimethylammonium chloride (CTACl) ratio of 2.76 , the specific surface area of the $\mathrm{LaMnAl}_{10} \mathrm{O}_{18}$ sample calcined at $1200{ }^{\circ} \mathrm{C}$ for $6 \mathrm{~h}$ was $42 \mathrm{~m}^{2} / \mathrm{g}$ when urea was used as an organic additive, which is higher than the value obtained for the material synthesized in the absence of urea $\left(29 \mathrm{~m}^{2} / \mathrm{g}\right)$. Boehmite and lanthanum nitrate were used by Jana et al. ${ }^{[42]}$ to synthesize high purity lanthanum hexaaluminates using advanced sol-gel processing. These authors added $\mathrm{LaAl}_{11} \mathrm{O}_{18}$ seeds to the precursor solution, thus resulting in a decrease of $100^{\circ} \mathrm{C}$ in the temperature at which the hexaaluminate structure is formed. As a result, near monophasic lanthanum hexaaluminate was formed at $1450{ }^{\circ} \mathrm{C}$.

The most widespread procedure for synthesizing hexaaluminates is based on coprecipitation (also known as the carbonate method), in which nitrate salts and $\left(\mathrm{NH}_{4}\right)_{2} \mathrm{CO}_{3}$ are used. Using this method, the precursors can be mixed homogeneously and precipitated at 
the same time. Compared to the sol-gel method outlined above, the co-precipitation process is very simple. It should also be noted that the pure hexaaluminate phase can be obtained at a relatively lower temperature using this co-precipitation method than when using the solid state reaction. For example, Groppi et al..$^{[43-45]}$ studied the synthesis of $\mathrm{BaAl}_{12} \mathrm{O}_{19}$ and BaMnxAl ${ }_{12-x} \mathrm{O}_{19}(x=0.5,1,2,3)$ by co-precipitation using $\left(\mathrm{NH}_{4}\right)_{2} \mathrm{CO}_{3}$. A starting solution of the metal nitrate precursors was prepared by dissolving salts in water at $60{ }^{\circ} \mathrm{C}$ under stirring. $\mathrm{HNO}_{3}$ was used to acidify the solution $(\mathrm{pH}=1)$ to avoid the precipitation of Al hydroxide. This solution was poured into an aqueous solution of $\left(\mathrm{NH}_{4}\right)_{2} \mathrm{CO}_{3}$ in excess. During precipitation and ageing, the $\mathrm{pH}$ remained at 7.5-8.0. The authors found that the $\mathrm{BaAl}_{12} \mathrm{O}_{19}$ hexaaluminates obtained had a specific surface area of between 10 and $15 \mathrm{~m}^{2} / \mathrm{g}$ after calcination at $1300{ }^{\circ} \mathrm{C}$. Jang et al. ${ }^{[46]}$ studied the synthesis of various hexaaluminates prepared by aqueous co-precipitation methods, with $\left(\mathrm{NH}_{4}\right)_{2} \mathrm{CO}_{3}$ and $\mathrm{NH}_{4} \mathrm{OH}$ as precipitating agents and with supercritical drying. The authors found that the textural properties of the hexaaluminates synthesized using the $\left(\mathrm{NH}_{4}\right)_{2} \mathrm{CO}_{3}$ co-precipitation method are, in general, better than those obtained when using $\mathrm{NH}_{4} \mathrm{OH}$ co-precipitation. Thus, the specific surface area of $\mathrm{Sr}_{0.8} \mathrm{La}_{0.2} \mathrm{MnAl}_{11} \mathrm{O}_{19}$ synthesized with $\left(\mathrm{NH}_{4}\right)_{2} \mathrm{CO}_{3}$ is $51 \mathrm{~m}^{2} / \mathrm{g}$ compared to $9 \mathrm{~m}^{2} / \mathrm{g}$ when synthesized by co-precipitation with $\mathrm{NH}_{4} \mathrm{OH}$. In addition to the precipitating agent, as the precipitation temperature increased, an improvement in the textural properties of the hexaaluminates was also observed. Similarly, Wang et al. ${ }^{[4]}$ synthesized $\mathrm{LaMn}_{\mathrm{x}} \mathrm{Al}_{12-\mathrm{x}} \mathrm{O}_{19}$ from metal nitrate solutions and $\mathrm{NH}_{4} \mathrm{OH}$. In this case, supercritical drying (SCD) and conventional oven drying $(C D)$ methods were used to extract the water from the hydrogel. The SCD method is key to maintaining a high surface area $\left(28 \mathrm{~m}^{2} / \mathrm{g}\right.$ for this method and $15 \mathrm{~m}^{2} / \mathrm{g}$ in the case of $C D$ ) and improving the catalytic performance for methane combustion. The particle size of the xerogel sample is less than $10 \mathrm{~nm}$, and it presents a complicated XRD 
pattern (see Figure 6). The presence of $\alpha-\mathrm{Al}(\mathrm{OH})_{3}$ and other unknown $\mathrm{La}, \mathrm{Mn}$ and $\mathrm{Al}$ hydroxides or oxides was also seen. In the case of the XRD pattern for the aerogel, $\alpha$-AlOOH is observed but peaks for La and $\mathrm{Mn}$ hydroxides are absent, thus indicating the high dispersion of species in the aerogel. After calcination, both samples transformed into hexaaluminates, with the presence of small amounts of $\mathrm{LaAlO}_{3}$.

Reverse microemulsion is another method that has been proposed to synthesize hexaaluminate nanocrystals with high specific surface areas. In this technique, aqueous nanometer-sized micelles dispersed in an oil phase are used as nanoreactors for controlled hydrolysis and condensation of the metal alkoxide, thus resulting in a homogeneous dispersion. The main disadvantages of this procedure are environmental, given the chemical reagents used, and the fact that the reproducibility of the method and yields are usually low. Zarur et al. ${ }^{[48-50]}$ proposed the synthesis of discrete barium hexaaluminate nanoparticles by sol-gel processing in reverse microemulsions. These authors studied the composition of the reverse microemulsion, the water/alkoxide ratio, the aging time and the drying techniques as synthetic variables. The best particle size and specific surface area of the final Bahexaaluminate obtained after calcination at $1300{ }^{\circ} \mathrm{C}$ were $30 \mathrm{~nm}$ and $160 \mathrm{~m}^{2} / \mathrm{g}$, respectively. With these conditions as a reference, a wide variety of hexaaluminates with high specific surface area have been successfully synthesized by modifying the synthetic parameters, such as composition of the microemulsion, aging time and drying techniques. Thus, for example, Sahu et al. ${ }^{[1]}$ used cyclohexane as the oil phase, Triton X-100/n-hexanol as the co-surfactant mixture and barium acetate and $\mathrm{NH}_{4} \mathrm{OH}$ as the aqueous phase. The barium hexaaluminate obtained presented a specific surface area of $90 \mathrm{~m}^{2} / \mathrm{g}$. Similarly, Teng et al. ${ }^{[52]}$ developed a new microemulsion system consisting of water, isopropanol and n-butanol to synthesize the material La0.95 $\mathrm{Ba}_{0.05} \mathrm{MnAl}_{11} \mathrm{O}_{19}$, with a specific surface area of $65 \mathrm{~m}^{2} / \mathrm{g}$. The same authors ${ }^{[53]}$ 
also prepared $\mathrm{Ce}_{x} \mathrm{Ba}_{1-\mathrm{x}} \mathrm{MnAl}_{11} \mathrm{O}_{19}$ type hexaaluminates $(\mathrm{x}=0.1-0.3)$ with a specific surface area of 25 to $74 \mathrm{~m}^{2} / \mathrm{g}$ using the reverse microemulsion method and inexpensive and nontoxic inorganic salts, instead of the alkoxide, as reagent. Following the same methodology, Jiang et al. ${ }^{[54]}$ used metal nitrate precursors and $\left(\mathrm{NH}_{4}\right)_{2} \mathrm{CO}_{3}$ as a precipitant to prepare Fesubstituted hexaaluminates with specific surface areas as high as $45 \mathrm{~m}^{2} / \mathrm{g}$. A catalytic support based on this methodology was reported by Wang et al, ${ }^{[55]}$ who prepared a microemulsion system by mixing polyoxyethylene (6) tridecyl alcohol ether, n-hexanol, cyclohexane and an aqueous solution of $\mathrm{Ba}\left(\mathrm{NO}_{3}\right)_{3} / \mathrm{Al}\left(\mathrm{NO}_{3}\right)_{3} /\left(\mathrm{NH}_{4}\right)_{2} \mathrm{CO}_{3}$. The mixed microemulsion was agitated for several hours, centrifuged, washed and calcined at $1200^{\circ} \mathrm{C}$ for $8 \mathrm{~h}$, followed by supercritical drying in ethanol at $260{ }^{\circ} \mathrm{C}$. The hexaaluminate obtained showed a specific surface area of $47 \mathrm{~m}^{2} / \mathrm{g}$.

Other methods that have been used to synthesize metal-substituted hexaaluminates include nitrate decomposition, ${ }^{[56-62]}$ hydrothermal synthesis, ${ }^{[63-65]}$ carbon-templating, ${ }^{[66-68]}$ freeze-drying ${ }^{[69,70]}$ and solution combustion synthesis, ${ }^{[71,72]}$ amongst others. The nitrate decomposition method is based on adding aqueous solutions of these salts to a polyethylene glycol/isopropyl alcohol mixture and, after a certain reaction time, which may be under pressure, drying and calcination steps. The textural properties obtained for these solids are usually comparable to those obtained in the materials synthesized by the sol-gel and coprecipitation methods under similar synthetic conditions. One of the disadvantages of this method is that the mixture of precursors is not homogeneous. For example, the hydrothermal method has been used by Mishra et al. ${ }^{[64]}$ with nitrate precursors of appropriate composition in the presence of aqueous urea. After calcination at $1400^{\circ} \mathrm{C}$, a Bahexaaluminate with a specific surface area of $22 \mathrm{~m}^{2} / \mathrm{g}$ was obtained. These authors proposed the following reaction sequence for synthesis of the hexaaluminate: hydrothermal 
precipitation of orthorhombic $\mathrm{BaCO}_{3}$ and a bohemite $(\gamma-\mathrm{AlOOH})$ precursor from the aqueous $\mathrm{Na}$ and $\mathrm{Al}$ nitrates in the presence of urea, formation of an interim mixture of $\mathrm{\gamma}-\mathrm{Al}_{2} \mathrm{O}_{3}, \mathrm{BaCO}_{3}$ and $\mathrm{Ba}-\mathrm{\beta}-\mathrm{Al}_{2} \mathrm{O}_{3}$ in the temperature range $800-1200{ }^{\circ} \mathrm{C}$, and formation of $\mathrm{BaO} \cdot 6 \cdot \mathrm{Al}_{2} \mathrm{O}_{3}$ powder with a $\beta-\mathrm{Al}_{2} \mathrm{O}_{3}$ type structure al $1400^{\circ} \mathrm{C}$.

A templating methodology was introduced recently into the zeolite field and subsequently extended to ordered mesoporous materials, where periodic pore systems are created by occluding molecular units in the resulting solid. This strategy is known as "endotemplating", and is also used in the case of metal oxides, where it is more generally known as the "citrate method". In a more recent approach, known as "exotemplating", extended porous structures provide the space in which a divided solid can form. Carbon is the ideal exotemplate given its easy removal by combustion, versatile porous characteristics, and relatively low cost. This strategy has been applied to synthesize mesoporous zeolite crystals and nanocrystalline zeolites, ${ }^{[73]}$ as well as high surface area oxides ${ }^{[74]}\left(\mathrm{TiO}_{2}, \mathrm{NiAl}_{2} \mathrm{O}_{4}\right.$, $\mathrm{LaFeO}_{3}$ ). The typical preparation of this type of oxide by templating involves impregnation of the carbon with concentrated solutions of the metal cations followed by drying and thermal treatment. There are no previous studies in which the effectiveness of carbon templating for the synthesis of oxides is presented, especially in this case, where temperatures as high as $1200{ }^{\circ} \mathrm{C}$ are required to obtain the hexaaluminate oxide. Under these conditions the carbon is removed and hexaaluminate formation could lead to severe sintering of the intermediate oxide phase once the carbon has been removed. For example, Santiago et al. ${ }^{[67]}$ synthesized LaFeAl ${ }_{11} \mathrm{O}_{19}$ hexaaluminates following a carbon-templating pathway and compared the results with those obtained using the conventional co-precipitation method (see Figure 7). The authors found that the specific surface area of $\mathrm{LaFeAl}_{11} \mathrm{O}_{19}$ hexaaluminates increased by a factor of up to 25 times when using the carbon-templating method. The main difference 
observed is that the co-precipitation method results in the formation of agglomerated spherical type particles, which form a hexaaluminate with a broad size distribution (range 40 to $110 \mathrm{~nm}$ ). The carbon-templating method produces finely dispersed hexaaluminate particles. These particles may result from the growth of small crystallites on the carbon surface and vigorous combustion of the carbon-precursor mixture. The strategy methods of synthesis and the textural properties have been summarized in Table 1.

\section{Metal-substituted and -supported hexaaluminates}

Catalytic combustion over M-substituted hexaaluminates occurs via a redox mechanism involving reversible variation of the oxidation state of the transition metal ion in the structure. As such, the nature and role of the transition metal ion in the structure have been investigated extensively. Thus, Mn-substituted hexaaluminates have been the most widely studied structures and also present the highest activity in, for example, the combustion of $\mathrm{CH}_{4}$. The chemical state of $\mathrm{Mn}$ ions in $\mathrm{BaMn}_{x} \mathrm{Al}_{12-\mathrm{x}} \mathrm{O}_{19-\alpha}$ hexaaluminates $(x=0.5,1-3)$ was analyzed by Bellotto et al. ${ }^{[44,75]}$ by X-ray absorption spectroscopy and structure refinement after X-ray powder diffraction analysis. At low charge (up to $x=1$ ), $M n$ was present preferentially at the tetrahedral $\mathrm{Al}(2)$ centers of $\mathrm{Ba}-\mathrm{B}_{-}-\mathrm{Al}_{2} \mathrm{O}_{3}$ as a divalent cation. ${ }^{[76]}$ The presence of $\mathrm{Ba}$ in the mirror planes acts as a charge compensation mechanism to balance the substitution of $\mathrm{Al}^{3+}$ with $\mathrm{Mn}^{2+}$. At higher $\mathrm{Mn}$ loads $(\mathrm{x} \geq 1)$, the occupation of the $\mathrm{Ba}$ centers reaches almost unity and $\mathrm{Mn}$ is preferably present at the octahedral $\mathrm{Al}(1)$ centers as $\mathrm{Mn}^{3+}$. The incorporation of $\mathrm{Mn}^{3+}$ at the octahedral $\mathrm{Al}(1)$ centers results in a reduction in the

specific surface area and is not observed to have a positive effect on the catalytic performance. Artizze-Duart et al. ${ }^{[77,78]}$ proposed that the catalytic activity is related to the $\mathrm{Mn}$ content and found that the highest activity was obtained for catalysts containing three 
Mn sites. However, these authors also found that the presence of excess $M n(x>3)$ leads to the formation of another phase (manganese oxide or spinel), which may be responsible for the decrease in catalytic performance in the case of the hexaaluminate with four $\mathrm{Mn}$ sites. The incorporation of $\mathrm{Mg}$ ions into $\mathrm{LaMnAl}_{11} \mathrm{O}_{19}$ resulted in increased specific catalytic activity per mol Mn. ${ }^{[79,80]}$ This behavior could be associated with stabilization of the $\mathrm{Mn}$ ions in a high oxidation state by the $\mathrm{Mg}^{2+}$ ions. $\mathrm{Li}$ and $\mathrm{Li}^{[80]}$ also reported that the partial substitution of $\mathrm{Mg}$ for $\mathrm{Mn}$ improves the sintering resistance, and the $\mathrm{Mg}$-containing sample has a higher specific surface area $\left(29 \mathrm{~m}^{2} / \mathrm{g}\right)$ than the unsubstituted sample $\left(18 \mathrm{~m}^{2} / \mathrm{g}\right)$. Jang et al. ${ }^{[46]}$ found that $\mathrm{LaMnAl}_{11} \mathrm{O}_{19}$ is much more active than $\mathrm{BaMnAl}_{11} \mathrm{O}_{19}$, and attributed the improved activity to the different oxidation state of $\mathrm{Mn}$ ions in the two types of hexaaluminates. Similarly, Li and Wang ${ }^{[81]}$ prepared $\mathrm{Mn}$-substituted Ba-La-hexaaluminate nanoparticles and found that the $\mathrm{Ba}_{0.2} \mathrm{La}_{0.8} \mathrm{MnAl}_{11} \mathrm{O}_{19}$ catalyst exhibited much higher activity than $\mathrm{BaMnAl}_{11} \mathrm{O}_{19}$ or $\mathrm{LaMnAl}_{11} \mathrm{O}_{19}$. In conclusion, it should be noted that both the degree of substitution and the nature of the large cations in the mirror plane significantly affect the $\mathrm{Mn}^{2+} / \mathrm{Mn}^{3+}$ redox cycle, and therefore the catalytic performance.

Fe has also been studied as an efficient promoter for the catalytic combustion of $\mathrm{CH}_{4}$. In this case, Fe was found to completely replace $\mathrm{Al}$ and lead to the formation of a $\mathrm{BaFe}_{12} \mathrm{O}_{19}$ type hexaferrite structure. Groppi et al., ${ }^{[82]}$ for example, synthesized samples of $\mathrm{BaFe}_{x} \mathrm{Al}_{(12-}$ x) $\mathrm{O}_{19}(\mathrm{x}=1,3,6,9,12)$ and found that $\mathrm{BaFe}_{12} \mathrm{O}_{19}$ calcined at $700{ }^{\circ} \mathrm{C}$ was active in the combustion of $\mathrm{CH}_{4}$. However, it was deactivated when the calcination temperature increased and after treatment at $900{ }^{\circ} \mathrm{C}$. The authors explained the observed deactivation via two possible mechanisms: sintering and partial reduction of $\mathrm{Fe}^{3+}$ to $\mathrm{Fe}^{2+}$. After calcination at $1300{ }^{\circ} \mathrm{C}, \mathrm{BaFe}_{6} \mathrm{Al}_{6} \mathrm{O}_{19}$ showed the best catalytic properties. However, its activity is lower than that of the Mn-substituted hexaaluminates. Naoufal et al. ${ }^{[35]}$ found that $\mathrm{Fe}^{3+}$ ions 
occupied the $\mathrm{S} 1$ and $\mathrm{S} 2$ octahedral centers in $\mathrm{BaFeAl}_{11} \mathrm{O}_{19}$. At an $\mathrm{Fe} / \mathrm{Ba}$ ratio of $2-4, \mathrm{Fe}^{3+}$ ions were found at two new octahedral centers ( $\mathrm{S} 3$ and $\mathrm{S4}$ ). The presence of $\mathrm{Fe}^{3+}$ in these two octahedral centers allowed the authors to explain the observed increase in activity. Similarly, Laassiri et al. ${ }^{[83]}$ synthesized $\mathrm{BaM}_{\mathrm{x}} \mathrm{Al}_{12-\mathrm{x}} \mathrm{O}_{19-\delta}$ hexaaluminates $(\mathrm{M}=\mathrm{Co}, \mathrm{Fe}, \mathrm{Mn}, \mathrm{x}=1,2)$ and found that the Mn-containing materials were more active than those containing Fe and Co, with the increase in $\mathrm{Mn}$ content enhancing the catalytic activity. These authors used various characterization techniques to clarify why the activity was improved. In the case of $\mathrm{Mn}$ containing hexaaluminates, the improvement in activity parallels the increase in specific surface area and reducible $\mathrm{Mn}$ content, as well as oxygen mobility. These results showed that multiple factors, including oxygen transfer, the oxidation state of the transition metal and surface concentration, determine the catalytic properties of hexaaluminates. In addition to $\mathrm{Mn}$ and Fe, which are more active, other metals that have been introduced into the structure of hexaaluminates include $\mathrm{Co}^{[39,83-85]} \mathrm{Cr},{ }^{[84,86]} \mathrm{Cu},{ }^{[33,78]} \mathrm{Mg},{ }^{[79,87,88]} \mathrm{Ni}^{, 62,84,89,90]} \mathrm{Ru}$ and Pt. ${ }^{[91]}$ Compared to $\mathrm{Mn}$ and Fe, the degree of substitution of these metals is relatively low, generally less than two metal ions, due to their size, which does not allow the substitution of $\mathrm{Al}^{3+}$ and may explain their limited catalytic activity. In the structures formed, $\mathrm{Ni}$ is divalent and coordinated octahedrally and pseudo-octahedrally, $\mathrm{Fe}$ and $\mathrm{Cr}$ are trivalent in octahedral coordination, and Co is both divalent and tetrahedrally coordinated and trivalent and octahedrally coordinated. In a detailed study, Gardner et al. ${ }^{\left[{ }^{90]}\right.}$ investigated the structure of five $\mathrm{Ni}$-substituted $\mathrm{Ba}_{0.75} \mathrm{Ni}_{y} \mathrm{Al}_{12-\mathrm{y}} \mathrm{O}_{19-\delta}$ hexaaluminated at various $\mathrm{Ni}$ loadings $(\mathrm{y}=$ $0.2,0.4,0.6,0.8$ and 1.0$)$ using several techniques. All samples exhibited the $\beta-\mathrm{Al}_{2} \mathrm{O}_{3}$ phases consistent with $\mathrm{Ni}$ substitution into the crystalline lattice of the hexaaluminate structure. The authors observed that, as the degree of $\mathrm{Ni}$ substitution into the structure lattice increased, the unit cell dimensions along the $c$ axis decreased. This result is consistent with 
$\mathrm{Ni}^{2+}$ substitution for $\mathrm{Al}^{3+}$ in the hexaaluminate crystalline structure. The EXAFS results also indicated that Ni preferentially exchanges with tetrahedrally coordinated $\mathrm{Al}^{3+}$. In the case of noble metals, a remarkable sintering is observed outside the structure, thus meaning that the catalytic activity is usually low, even lower than that of hexaaluminates substituted with transition metals. ${ }^{[92,93]}$

Pd catalysts supported on hexaaluminates are the most widely studied due to their good performance in $\mathrm{CH}_{4}$ combustion. For example, Sekizawa et al. ${ }^{[3,94]}$ evaluated the catalytic activity of $\mathrm{Pd} / \mathrm{Sr}_{0.8} \mathrm{La}_{0.2} \mathrm{XA}_{11} \mathrm{O}_{19}(\mathrm{X}=\mathrm{Al}$ and $\mathrm{Mn})$. The results showed that the activity of $\mathrm{Pd} / \mathrm{Sr}_{0.8} \mathrm{La}_{0.2} \mathrm{~A}_{12} \mathrm{O}_{19}$ increases initially with temperature but then decreases at $700{ }^{\circ} \mathrm{C}$. The authors explained this behavior as being due sintering of the Pd particles upon dissociation of PdO into metallic Pd. If the hexaaluminate used as a support is an Mn-substituted hexaaluminate $(X=M n)$, the loss of activity is reduced because the support is also active. The presence and absence of $\mathrm{NO}$ in methane combustion over $0.9 w t . \% \mathrm{Pd} / \mathrm{La}_{1-x} \mathrm{Sr}_{x} \mathrm{MnAl}_{11} \mathrm{O}_{19}$ was evaluated by Öcal et al. ${ }^{[95]}$ using the steady-state isotopic transient kinetic analysis and conventional steady-state reaction techniques. The presence of $\mathrm{NO}_{2}$, formed from the reaction between $\mathrm{NO}$ and $\mathrm{O}_{2}$, boosted the site activity required for the formation of $\mathrm{CO}_{2}$. The manner in which the oxidation state of Pd evolves with calcination temperature has been studied by Sohn et al., ${ }^{[96]}$ who found that the supported Pd oxide in $\mathrm{Sr}_{0.8} \mathrm{La}_{0.2} \mathrm{MnAl}_{11} \mathrm{O}_{19}$ is reduced to metallic $\mathrm{Pd}$ when heated at $1000^{\circ} \mathrm{C}$. If the temperature is increased to $1200{ }^{\circ} \mathrm{C}$, the formation of $\mathrm{Pd}^{\delta+}$ species occurs due to the strong interaction between the $\mathrm{Pd}$ and hexaaluminate.

The activity and catalytic stability of $\mathrm{Pd} / \mathrm{Mn}$-substituted hexaaluminates was compared with a reference $\mathrm{Pd} / \mathrm{Al}_{2} \mathrm{O}_{3}$ catalyst, ${ }^{[97,98]}$ and it was found that $\mathrm{Pd} / \mathrm{Al}_{2} \mathrm{O}_{3}$ showed greater activity than the hexaaluminates but that both were deactivated as the reaction progressed 
due to the decomposition of PdO into Pd. The Pd/Mn-substituted hexaaluminates exhibited greater stability due to the transfer of oxygen from the oxidized manganese centers to the reduced palladium centers, thus preventing the reduction of $\mathrm{PdO}$ to $\mathrm{Pd}$ (see Figure 8). When $\mathrm{Pd}(\mathrm{acac})_{2}$ is used as palladium precursor, catalysts with more dispersed $\mathrm{Pd}$ are obtained, thus resulting in a higher catalytic activity in the methane oxidation reaction. Rapid deactivation is also observed as a consequence of the sintering of small Pd particles given the weak interaction between Pd and the support. ${ }^{[99,100]}$

\section{Catalytic performances of hexaaluminates}

\subsection{Combustion of $\mathrm{CH}_{4}$}

The catalytic combustion of methane has been considered to be a promising alternative to conventional thermal combustion for energy production due to the low emissions of polluting gases that are produced. As this organic molecule is highly resistant to combustion, the catalysts to be used must be thermally resistant $\left(>1200{ }^{\circ} \mathrm{C}\right.$ ) and stable, as well as selective for incineration. One of the first published studies of this reaction was presented by Machida et al., ${ }^{[28]}$ who evaluated the catalytic behavior of $\mathrm{BaMAl}_{11} \mathrm{O}_{19}(\mathrm{M}=\mathrm{Co}, \mathrm{Cr}, \mathrm{Fe}, \mathrm{Mn}$, Ni) and found that all metal-substituted hexaaluminates exhibited higher activity than the unsubstituted $\mathrm{BaAl}_{12} \mathrm{O}_{19}$ catalyst. In addition, the $\mathrm{Mn}$-substituted hexaaluminates were the most active, exhibiting a $\mathrm{T}_{10}$ of $540^{\circ} \mathrm{C}$ and $\mathrm{T}_{90}$ of $740{ }^{\circ} \mathrm{C}$. The following order of reactivity was found: $\mathrm{Mn}>\mathrm{Fe}>\mathrm{Co}=\mathrm{Cr}=\mathrm{Ni}$. The same reactivity order was found for $\operatorname{LaMAl} \mathrm{I}_{11} \mathrm{O}_{19}$ catalysts, ${ }^{[101]}$ thus indicating that the combustion performance is mainly determined by the nature of the transition metal. Since these first studies, subsequent work by a large number of researchers has improved the activity and reaction mechanism of the combustion of $\mathrm{CH}_{4}$ on hexaaluminates. For example, Artizzu et al. ${ }^{[33,78]}$ found that the introduction of $\mathrm{Cu}^{2+}$ ions 
into the Ba-hexaaluminate structure leads to a fairly active catalyst ( $T_{10}$ and $T_{50}$ of 510 and $740{ }^{\circ} \mathrm{C}$, respectively). Similarly, a synergistic effect was reported by Yan et al., ${ }^{[39]}$ who evaluated the doubly Ba-substituted hexaaluminate $\mathrm{BaMn}_{0.5} \mathrm{Co}_{0.5} \mathrm{Al}_{11} \mathrm{O}_{19}$ as catalyst in comparison to mono-substituted hexaaluminates. These authors found that Lahexaaluminates showed higher catalytic performance for all M-substituted systems in relation to Ba-hexaaluminates. A similar promoting effect was also observed for $\mathrm{Sr}_{0.8} \mathrm{La}_{0.2} \mathrm{MnAl}_{11} \mathrm{O}_{19}{ }^{[101]}$ and $\mathrm{LaMn}_{1-\mathrm{x}} \mathrm{Mg}_{\times} \mathrm{Al}_{11} \mathrm{O}_{19}{ }^{[80]}$ (see Figure 9), evaluating NOx emissions at the same time as methane and propane combustion. ${ }^{[32]}$ The catalytic performance of Fesubstituted Ba-hexaaluminates is related to the $\mathrm{Fe}^{3+}$ present at octahedral sites both in the bulk hexaaluminate and at the subsurface of the oxygen layer. ${ }^{[35]}$ The catalytic behavior is governed by electronic and structural factors. The catalytic activity of $\mathrm{Mn}_{3} \mathrm{O}_{4} /$ hexaaluminate composites was evaluated by Machida et al. ${ }^{[102]}$ as a function of $\mathrm{Mn}_{3} \mathrm{O}_{4}$ loading and the metal composition of the spinel surface layer. It was found that air oxidation derived composites showed excellent specific activities that were better than those for the corresponding $\mathrm{Mn}_{3} \mathrm{O}_{4} /$ hexaaluminates prepared using the conventional impregnation method (see proposed mechanism in Figure 10).

The evolution of the catalytic behavior of other oxides, such as $\mathrm{LaMnO}_{3}$ perovskites, has also been compared with $\mathrm{LaMnAl}_{11} \mathrm{O}_{19-\mathrm{d} .}{ }^{[103]}$ The authors of this study found that catalytic performance is regulated by bulk oxygen mobility and, as a consequence, methane oxidation proceeds via the Mars van-Krevelen mechanism.

Among noble metals, $\mathrm{Pd}$ is known to exhibit the best performance for the combustion of methane and the lowest volatility. Thus, Sidwell et al. ${ }^{[104]}$ reported a comparison between two metal-substituted hexaaluminate catalysts and a supported catalyst ( $3 \mathrm{wt} . \% \mathrm{Pd} / \mathrm{Y}-\mathrm{Al}_{2} \mathrm{O}_{3}$ ), finding that the $\mathrm{Pd}$-substituted catalyst $\left(\mathrm{Sr}_{0.5} \mathrm{Pd}_{0.5} \mathrm{Al}_{11} \mathrm{O}_{18-\alpha}\right)$ is suitable for low-temperature 
performance and $\mathrm{La}_{x} \mathrm{Sr}_{y} \mathrm{Mn}_{0.4} \mathrm{Al}_{11} \mathrm{O}_{18-\alpha}$ is a good high-temperature catalyst. The catalytic properties of $\mathrm{Pd}$ supported on hexaaluminates ( $\mathrm{Sr}_{0.8} \mathrm{La}_{0.2} \mathrm{XAl}_{11} \mathrm{O}_{19}, \mathrm{X}=\mathrm{Al}$ and $\mathrm{Mn}$ ) was also studied by Sekizawa et al., ${ }^{[31]}$ who found that the catalytic performance initially increases with temperature, subsequently decreasing at about $700^{\circ} \mathrm{C}$. This drop in activity is related to the dissociation of PdO into metallic Pd species observed at low oxygen partial pressures and is due to the removal of adsorbed oxygen species necessary for the catalytic reaction.

A synergistic effect has been reported over Pd-modified manganesehexaaluminates, ${ }^{[105]}$ with the magnitude of this effect being found to depend on the palladium precursor: it is higher for palladium nitrate and palladium acetate than for tetrachloropalladic acid. In the same way, the higher $\mathrm{PdO} / \mathrm{Pd}$ ratio found in the nitrate and acetate Pd-modified manganese-hexaaluminate catalysts, together with the high oxygen mobility due to the presence of manganese, provide a synergistic effect in methane oxidation in the light-off temperature region.

$\mathrm{Pd}, \mathrm{Pd}-\mathrm{Pt}, \mathrm{Pd}-\mathrm{Au}$ and Pt supported on three-dimensionally ordered macroporous LaMnAl $_{11} \mathrm{O}_{19}$ (3DOM LMAO) have been used as catalysts. ${ }^{[72,106]}$ Among the PdPt/3DOM LMAO catalysts, $1.14 \mathrm{Pd}_{2.8} \mathrm{Pt} / 3 \mathrm{DOM} \mathrm{LMAO}$ exhibited the best catalytic performance $\left(\mathrm{T}_{50}=\right.$ $372{ }^{\circ} \mathrm{C}$; see Figure 11).

\subsection{Reforming of methane to syngas}

The reforming of methane with $\mathrm{CO}_{2}$, or dry reforming, is a reaction initially proposed for the industrial production of $\mathrm{CO}$ and $\mathrm{H}_{2}$. With respect to other types of reforming, it has the great advantage of not requiring a previous separation of $\mathrm{CO}_{2}$ to produce the $\mathrm{CO}$ and $\mathrm{H}_{2}$ that would allow liquid fuels to be obtained via the Fischer-Tropsch reaction. Catalysts based on noble and transition metals have been reported to be very active for the dry reforming 
reaction, with the most widely studied being those based on $\mathrm{Rh}, \mathrm{Pt}, \mathrm{Ru}, \mathrm{Ni}$ and $\mathrm{Co}^{[43,62,68,107]}$ (see Figure 12). The formation of coke during the reaction, which is one of the main disadvantages, can be reduced by adding promoters, by using catalytic supports with basic properties, and even by reducing the pressure and temperature conditions under which the reaction is carried out. ${ }^{[68]}$ In this regard, hexaaluminate-like catalysts could exhibit significant advantages as they can incorporate metals that reduce coke deposits in their structure. In addition, if the reaction temperature can be reduced significantly, coke deposition may also be reduced. ${ }^{[108]}$ At least two forms of deposited carbon, namely graphite and carbide, have observed during methane reforming with $\mathrm{CO}_{2} \cdot{ }^{[109]}$ Metal particle sintering and phase transformation have also been reported to result in catalyst deactivation. ${ }^{[62]}$

The partial oxidation of methane (POM) was evaluated by Chu et al. ${ }^{[110]}$ using $\mathrm{BaNi}_{y} \mathrm{Al}_{12-\mathrm{y}} \mathrm{O}_{19-\delta}$ catalysts $(\mathrm{y}=0.3,0.6,0.9,1)$. All the hexaaluminates prepared had an MPtype structure and no nickel oxide was observed, which may indicate a high dispersion of the Ni species. These catalysts showed high activity and selectivity, with a $\mathrm{CH}_{4}$ conversion of $92 \%$ and $\mathrm{CO}$ selectivity of $95 \%$ at $850{ }^{\circ} \mathrm{C}$. They also presented an excellent ability to suppress carbon deposition and loss of active phase, exhibiting high stabilities after reaction for $100 \mathrm{~h}$. The same authors ${ }^{[108]}$ reported the catalytic performance of a NiO/Ba-hexaaluminate, which showed a $\mathrm{CH}_{4}$ conversion of $95 \%$ and $\mathrm{CO}$ selectivity of $98 \%$ at $850{ }^{\circ} \mathrm{C}$.

The activity of $\mathrm{Ni} / \mathrm{Al}_{2} \mathrm{O}_{3}$ and $\mathrm{BaNi}_{x} \mathrm{Al}_{12-\mathrm{x}} \mathrm{O}_{19-\alpha}(\mathrm{x}=0.25,0.5$ and 1$)$, which have $\mathrm{a}$ hexaaluminate-type structure, was compared by Utaka et al..111] These authors found that hexaaluminate calcined at $1400{ }^{\circ} \mathrm{C}$ exhibited a more stable and better behavior than the former calcined at $1000{ }^{\circ} \mathrm{C}$. The $\mathrm{BaNiAl}_{11} \mathrm{O}_{19-\alpha}$ catalyst calcined at $1400{ }^{\circ} \mathrm{C}$ and reduced to $1000{ }^{\circ} \mathrm{C}$ showed a higher activity than $\mathrm{BaNiAl}_{11} \mathrm{O}_{19-\alpha}$ calcined at $1200{ }^{\circ} \mathrm{C}$ and reduced to 800 
${ }^{\circ} \mathrm{C}$. This behavior was explained by the authors as being due to the presence of a Ni-rich surface and highly dispersed $\mathrm{Ni}$ species.

A systematic study of $\mathrm{Ni} / \mathrm{Ba}$-hexaaluminate catalysts synthesized by the impregnation method for the production of syngas via a CO methanation reaction has been reported by Gao et al. ${ }^{[112]}$ Similarly, Rh supported on hexaaluminates $\left(\mathrm{BaAl}_{12} \mathrm{O}_{19}, \mathrm{CaAl}_{12} \mathrm{O}_{19}\right.$ and $\left.\mathrm{SrAl}_{12} \mathrm{O}_{19}\right)$ has been investigated by Majocchi et al. ${ }^{[113]}$ These latter authors compared the results obtained with a commercial $\mathrm{Rh} / \alpha-\mathrm{Al}_{2} \mathrm{O}_{3}$ and found that hexaaluminate catalysts were less stable, active and selective than the commercial catalyst. The following order of selectivity for $\mathrm{CO} / \mathrm{H}_{2}$ was found, depending on the supports: $\mathrm{Rh} / \alpha-\mathrm{Al}_{2} \mathrm{O}_{3}>\mathrm{Rh} / \mathrm{CaAl}{ }_{11} \mathrm{O}_{19}=\mathrm{Rh} / \mathrm{SrAl}{ }_{12} \mathrm{O}_{19}=$ $\mathrm{Rh} / \mathrm{BaAl}_{12} \mathrm{O}_{19}$. The chemical looping partial oxidation of methane has been proposed as a method for producing syngas with a suitable $\mathrm{H}_{2} / \mathrm{CO}$ ratio, thereby avoiding the risk of explosion, using Ba-hexaaluminate as catalysts. ${ }^{[114-117]}$

Some of the hexaaluminates that have been reported as catalysts in the dry methane reforming reaction (DRM) include $\mathrm{LaNi}_{x} \mathrm{Al}_{12-\mathrm{x}} \mathrm{O}_{19}(0<\mathrm{x}<1),{ }^{[60,64]} \mathrm{Ca}_{1-\mathrm{x}} \mathrm{La}_{\mathrm{x}} \mathrm{NiAl}_{11} \mathrm{O}_{19-\delta}{ }^{[89]}$ $\mathrm{BaNi}_{x} \mathrm{Al}_{12-\mathrm{x}} \mathrm{O}_{19}(0<\mathrm{x}<1)^{[118]}$ and $\mathrm{ANiAl}_{11} \mathrm{O}_{19}(\mathrm{~A}=\mathrm{Ba}, \mathrm{Ca}, \mathrm{Ce}, \mathrm{La}, \mathrm{Nd}, \mathrm{Pr}, \mathrm{Sr}) .^{[56-58,61,119]}$ The authors of these studies found that activity increases with degree of $\mathrm{Ni}$ substitution, although the amount of carbon produced also increases. ${ }^{[62,118]} \mathrm{Xu}$ et al. ${ }^{[62]}$ reported that $\mathrm{Ni}$ modified hexaaluminates exhibit a more effective catalytic performance and lower carbon deposition than other $\mathrm{Ni}$ supported catalysts such as $\mathrm{Ni} / \mathrm{Al}_{2} \mathrm{O}_{3}, \mathrm{NiO} / \mathrm{CaO}, \mathrm{NiO} / \mathrm{SrO}, \mathrm{NiO} / \mathrm{BaO}$. The nature of the large cations in the structure significantly affects the reducibility and activity of the catalysts. ${ }^{[61]}$ Thus, a lower reduction temperature was observed for the LaNiAl ${ }_{11} \mathrm{O}_{19-\delta}$-modified hexaaluminate than for $\mathrm{ANiAl}_{11} \mathrm{O}_{19}(\mathrm{~A}=\mathrm{Ba}, \mathrm{Ca}, \mathrm{Sr})$. In this latter series of hexaaluminates, it was found that the $\mathrm{Ni}$ reduction temperature decreases with increasing ionic radius of the alkaline earth metals. ${ }^{[61]}$ 
A series of substituted $\mathrm{Ca}_{1-x} \mathrm{La}_{x} \mathrm{NiAl}_{11} \mathrm{O}_{19-\delta}$ hexaaluminates was prepared by Ikkour et al. ${ }^{[89]}$ After calcination at $1100{ }^{\circ} \mathrm{C}$, the specific surface areas of all catalysts was found to be between 1 and $6 \mathrm{~m}^{2} / \mathrm{g}$, and the presence of hexaaluminate was only confirmed by XRD after the incorporation of lanthanum. $\mathrm{Ca}_{0.5} \mathrm{La}_{0.5} \mathrm{NiAl}_{11} \mathrm{O}_{19-\delta}$ presented the highest percentage of $\mathrm{Ni}$ reduced at the surface and also showed a high activity for $\mathrm{H}_{2} / \mathrm{CO}$ production and high reaction stability after $300 \mathrm{~h}$.

The effect of $\mathrm{Ce}$ and $\mathrm{Pr}$ on the structure and catalytic performance of $\mathrm{LaNiAl}_{11} \mathrm{O}_{19}$ has been investigated by Zhang et al., ${ }^{[56,57]}$ who found that the addition of $\operatorname{Pr}$ can accelerate reduction of the $\mathrm{Ni}^{2+}$ ions in $\mathrm{La}_{0.8} \mathrm{Pr}_{0.2} \mathrm{NiAl}_{11} \mathrm{O}_{19}$. However, a $\mathrm{Ce}^{4+} / \mathrm{Ce}^{3+}$ redox reaction occurs in $\mathrm{La}_{0.8} \mathrm{Ce}_{0.2} \mathrm{NiAl}_{11} \mathrm{O}_{19}$ during the reaction that reduce the electron transfer between $\mathrm{Ni}$ and $\mathrm{La}$ ions. As such, $\mathrm{Pr}$ is a more valuable additive than $\mathrm{Ce}$ in these $\mathrm{Ni}$-based catalysts. All of these effects contribute to the improvement of the catalytic activity of modified Laxaxaaluminates. Roussiere et al. ${ }^{[70]}$ have proposed a mechanism for the growth of $\mathrm{NiO}$ nanoparticles in the hexaaluminate phase in order to understand the stability of these nanoparticles under reducing conditions. The amount of $\mathrm{Ni}$ in the hexaaluminate $\mathrm{ANi}_{\mathrm{y}} \mathrm{Al}_{12-}$ ${ }_{y} \mathrm{O}_{19}(\mathrm{~A}=\mathrm{Ba}, \mathrm{La}, \mathrm{Sr} ; 0<\mathrm{y} \leq 1)$ should be as low as $\mathrm{y}=0.25$ to control the textural growth of $\mathrm{NiO}$ particles (tetrahedra) and their high dispersion in the form of nanoparticles. Furthermore, the calcination temperature must be sufficient $\left(1250^{\circ} \mathrm{C}\right)$ to maintain an adequate concentration of surface centers otherwise excess $\mathrm{Ni}$ causes aggregation by forming larger $\mathrm{NiO}$ particles, thus resulting in carbon deposition. ${ }^{[62,69]}$ Recently, $\mathrm{BaFe}_{2} \mathrm{Al}_{10} \mathrm{O}_{19}$, $\mathrm{BaFe}_{3} \mathrm{Al}_{9} \mathrm{O}_{19}$ and bimetallic $\mathrm{BaFe}_{2} \mathrm{MAl}_{9} \mathrm{O}_{19}(\mathrm{M}=\mathrm{Mn}, \mathrm{Ni}$, and $\mathrm{Co})$ hexaaluminates were also studied in this reaction. ${ }^{[120]}$ The effect of $\mathrm{Mn}, \mathrm{Ni}$ and $\mathrm{Co}$ doping on the structure, redox activity and stability was investigated using several techniques. The presence of doped metals meant that hexaaluminate was only present as $\beta-\mathrm{Al}_{2} \mathrm{O}_{3}$, remaining stable during the 
$\mathrm{CH}_{4}$ reduction step. $\mathrm{BaFe}_{2} \mathrm{CoAl}_{9} \mathrm{O}_{19}$ exhibited good reactivity for syngas production with high $\mathrm{CH}_{4}$ conversion, high syngas yield, a desirable $\mathrm{H}_{2} / \mathrm{CO}$ ratio and stability.

The steam reforming of methane has also been reported by various authors over $\mathrm{Ni}$ substituted Sr hexaaluminates. ${ }^{[121,122]}$

\subsection{Transformation of $\mathrm{N}_{2} \mathrm{O}$}

$\mathrm{N}_{2} \mathrm{O}$ mitigation is an important topic due to the adverse consequences of this harmful gas in the atmosphere. This polluting gas can be emitted by vehicle exhaust pipes or as a byproduct of the oxidation of ammonia in Pt/Rh-based catalytic systems. One of the main challenges that has been posed is to treat $\mathrm{N}_{2} \mathrm{O}$ in the process gases at high temperature. These conditions assume that the catalyst must be active and stable under wet oxidation conditions at $800-900{ }^{\circ} \mathrm{C}$. The structure and characteristics of hexaaluminates make them suitable catalysts for carrying out these reactions under these conditions. Pérez-Ramírez et al. $^{[123-126]}$ have evaluated the catalytic behavior of $A B A{ }_{12} \mathrm{O}_{19}$ hexaaluminates $(A=B a, L a ; B=$ $\mathrm{Fe}, \mathrm{Mn}$ and $\mathrm{Ni}$ ) for the decomposition of $\mathrm{N}_{2} \mathrm{O}$, simulating the conditions at the outlet in the ammonia burners of nitric acid plants (see Figure 13). Fe- and Mn-containing hexaaluminates showed the highest activities, whereas Ni-containing catalysts were less active than unsubstituted hexaaluminate. ${ }^{[123]}$ These researchers also studied the effect of reactor feed gas compositions on catalytic performance and found that the presence of NO has no effect on activity, whereas the presence of $\mathrm{O}_{2}$ and $\mathrm{H}_{2} \mathrm{O}$ inhibited activity, a behavior that they attributed to a possible competitive adsorption on the active centers in the catalysts. ${ }^{[126]}$ In various related studies, Lietti et al. ${ }^{[84,127,128]}$ evaluated the catalytic performance of a BaMnAl ${ }_{11} \mathrm{O}_{19}$ catalyst in the combustion of $\mathrm{NH}_{3}$-containing gasified biomass-derived fuels. These authors detected significant amounts of NO, which increased with temperature up to 
a maximum of about $750{ }^{\circ} \mathrm{C}$. Above this temperature, the NO concentration decreased as a result of a selective non-catalytic reduction process.

$\mathrm{N}_{2} \mathrm{O}$ has also been seen as a promising green propellant given its numerous advantages, such as extremely low toxicity, self-pressurization, and compatibility of $\mathrm{N}_{2} \mathrm{O}$ with common building materials. In view of the extreme operating conditions for $\mathrm{N}_{2} \mathrm{O}$ decomposition found in propulsion systems $\left(\right.$ vol $_{\mathrm{N} 20} \%=30-100 \%, \mathrm{~T}>1000{ }^{\circ} \mathrm{C}$, Ea $\approx 250$ $\mathrm{kJ} / \mathrm{mol}$ ), several studies have aimed to find a suitable catalyst that is capable of initiating $\mathrm{N}_{2} \mathrm{O}$ decomposition at low temperature while being stable at high temperatures. For example, Zhu et al. ${ }^{[19,92,93]}$ have developed a $\mathrm{Balr}_{\mathrm{y}} \mathrm{Fe}_{1-\mathrm{y}} \mathrm{Al}_{11} \mathrm{O}_{19}$ catalyst $(\mathrm{y}=0.2,0.5$ and 0.8$)$ that exhibits both high activity and excellent stability for this reaction. These authors found that the decomposition of $\mathrm{N}_{2} \mathrm{O}$ begins at $323^{\circ} \mathrm{C}$ and complete conversion is obtained at $450{ }^{\circ} \mathrm{C}$. The catalyst can undergo complete conversion at $500{ }^{\circ} \mathrm{C}$ and be stable for $26 \mathrm{~h}$, which contrasts with the rapid deactivation observed in the case of an $\mathrm{Ir} / \mathrm{Al}_{2} \mathrm{O}_{3}$ catalyst. The authors also indicate that the Ir species present in the hexaaluminate network are active centers, while the species outside the crystal structure of the hexaaluminate are susceptible to sintering and are less active in this reaction. The presence of Fe facilitates the incorporation of Ir into the hexaaluminate structure. A combined XRD and ${ }^{57} \mathrm{Fe}$ Mossbauer spectroscopy study allowed the identification of the crystallographic Fe and Ir centers in the hexaaluminate Balr ${ }_{0.2} \mathrm{FeAl}_{10.8} \mathrm{O}_{19} .{ }^{[12]}$ This study was subsequently extended to the case of $\mathrm{Ru}$, which is very interesting due to its activity as a catalyst, but with limitations when compared to other metals such as Ir, Pd, Pt and Rh given its high volatility (see proposed mechanism in Figure 14). ${ }^{[129]}$ One possible solution to this problem is to develop a two-bed reactor in which the Ir-hexaaluminate or other more active catalyst constitutes the front bed while the back bed requires a more thermally stable catalyst. In this regard, Mn-substituted La- 
hexaaluminate $\left(\operatorname{LaMn}_{x} \mathrm{Al}_{(12-x)} \mathrm{O}_{19}\right)$ and Ba-hexaaluminate $\left(\mathrm{BaMn}_{\mathrm{x}} \mathrm{Al}_{(12-x)} \mathrm{O}_{19}\right)$ catalysts have been studied. ${ }^{[130]}$ These authors reported that the Ba-hexaaluminate exhibits higher activity than the La-hexaaluminate at a given Mn content, which may be related to the presence of active $\mathrm{Mn}^{3+}$ sites in the octahedral position of the Mn-substituted Ba-hexaaluminate.

Other catalytic applications reported for these materials include combustion of methanol over La, Mn-hexaaluminate materials, ${ }^{[71]}$ decomposition of ammonium dinitramide (AND)- and hydroxyl ammonium nitrate (HAN)-based liquid monopropellants using $\mathrm{Sr}_{0.8} \mathrm{La}_{0.2} \mathrm{MnAl}_{11} \mathrm{O}_{19},{ }^{[131]}$ steam reforming of tars using $\mathrm{BaNi}_{x} \mathrm{Al}_{12-\mathrm{x}} \mathrm{O}_{19}{ }^{[121,132,133]} \mathrm{H}_{2} \mathrm{~S}$ decomposition using $\mathrm{LaFe}_{x} \mathrm{Al}_{12-\mathrm{x}} \mathrm{O}_{19}\left(\mathrm{LaFe}_{\mathrm{x}}, \mathrm{x}=2,4,6,8,10\right.$ and 12) (see Figure 15), ${ }^{[134]}$ partial oxidation of tetradecane $\left(n-C_{14}\right)$, dibenzothiophene (DBT) and 1-methylnaphthalene (1-MN) as model reaction compounds for a series of Ni-substituted lanthanum hexaaluminate catalysts, ${ }^{[135]} \mathrm{La}_{0.9} \mathrm{Ni}_{y} \mathrm{Al}_{11.95-y} \mathrm{O}_{19-\delta}(y=1.0,0.8,0.4$ and 0.2$),{ }^{[12]} \mathrm{NH}_{3}$ decomposition to $\mathrm{CO}_{x}$-free hydrogen using Ru/Ba-hexaaluminate, ${ }^{[55]}$ a Ba-hexaaluminate catalyst for the decarboxylation of biomass-derived itaconic acid to bio-based methacrylic acid, ${ }^{[136]}$ and a $\mathrm{ZrO}_{2}$-modified $\mathrm{Ni} / \mathrm{LaAl}_{11} \mathrm{O}_{18}$ catalyst for $\mathrm{CO}$ methanation. ${ }^{[137]}$

More information about the catalytic performance and reaction conditions have been summarized in Table 2.

Several authors have carried out development work and industrial applications of hexaaluminates that have been collected in international patents. Metal-exchanged hexaaluminate catalysts for the methane combustion, particularly for use in natural gas fired gas turbines, is reported by Wickham and Cook. ${ }^{[138]}$ The authors indicate that these catalysts are the particular interest because exhibit good catalytic performance and stability at high temperatures for extended periods, minimizing the generation of undesired levels of NOx 
species (less than about $10 \mathrm{mg} / \mathrm{dm}^{3}$ ). Metal exchanged catalysts are also useful for oxidation of volatile organic compounds (VOC), particularly hydrocarbons. The hexaaluminate structure $\left(\mathrm{La}_{x} \mathrm{Sr}_{y} \mathrm{Mn}_{0.4} \mathrm{Al}_{11} \mathrm{O}_{19}\right.$, being $\left.\mathrm{x}+\mathrm{y}=0.6\right)$ is observed after calcination at $1300{ }^{\circ} \mathrm{C}$ with a specific surface area of $13.5 \mathrm{~m}^{2} / \mathrm{g}$. Schunk et al. ${ }^{[139]}$ reported a hexaaluminate-containing Cobalt and at least one further element from $\mathrm{La}, \mathrm{Ba}$ and $\mathrm{Sr}$ for dry reforming of hydrocarbons at $700{ }^{\circ} \mathrm{C}$ and 5 bar. The work included in the patent presented by Ferrandon ${ }^{[140]}$ is directed to the synthesis of new hexaaluminate formulations applied as catalysts for the production of hydrogen from organic compounds that overcomes the problems of catalyst poisoning and deactivation by coking and high temperature sintering.

\section{Thermal insulation and oxidation protection}

Thermal-barrier (TBC) and oxidation-resistant coatings (ORC) are used to protect gas turbine components in power plants and aircraft jet engines, and as fibers in oxide-based ceramic composites. The materials for this application must exhibit low thermal conductivity, high thermal-shock resistance, hot corrosion resistance and long-term stability at high temperatures. Although yttria-partially-stabilized zirconia (Y-PSZ) is the proposed material for TBC applications, the deterioration observed in its thermo-physical properties at $1100^{\circ} \mathrm{C}$ means that other materials, such as hexaaluminates, may also be a good option. ${ }^{[141-145]}$ Indeed, hexaaluminates permit operating temperatures above $1300{ }^{\circ} \mathrm{C}$ because of their thermal stability and electrically insulating properties. Several methods have been proposed to produce homogeneous coatings, including atmospheric plasma spraying (APS), electronbeam physical vapor deposition (EB-PVD), low-pressure plasma spraying (LPPS), high-velocity oxygen fuel spraying (HVOF), and chemical vapor deposition (CVD). ${ }^{[146-149]}$ The APS method

has been used by Sun et al. ${ }^{[147,148]}$ to prepare porous coatings using powdered mixtures of 
$\operatorname{LaMgAl}_{11} \mathrm{O}_{19} /$ graphite (see Figure 16). The microstructure, mechanical properties and thermal cycling behavior of the coatings synthesized, as well as the spraying power required to prepare them, were studied. This method was also used by Sun et al. ${ }^{[144]}$ to prepare $\mathrm{GdMgAl}_{11} \mathrm{O}_{19}$, which exhibits much better $\mathrm{Ca}-\mathrm{Mg}$-Al-silicate (CMAS) resistance at $1350{ }^{\circ} \mathrm{C}$ than conventional YSZ coatings because of the presence of Gd and Mg. More recently, APS hexaaluminate ceramic coatings have been heat-treated and then exposed to molten CMAS to evaluate their hot corrosion degradation. ${ }^{[150]}$ CMAS was found to completely infiltrate into hexaaluminate coatings and form a corroded bilayer comprising a porous outer layer and a dense inner layer. $\mathrm{CaAl}_{2} \mathrm{Si}_{2} \mathrm{O}_{8}$ and $\mathrm{MgAl}_{2} \mathrm{O}_{4}$ formation were the predominant reaction products in the outer layer. The isothermally heat-treated hexaaluminate coatings exhibited increased and widened vertical microcracks, thereby providing penetration channels and determining the penetration kinetics of CMAS into hexaaluminate, which therefore suffered more severe CMAS attack (see Figure 17). The synthesis of $\mathrm{CeAl}_{11} \mathrm{O}_{18}$ was reported by Naga et al. ${ }^{[151]}$ using cerium nitrate and aluminum triisopropoxide as precursors. After hot pressing at $1550{ }^{\circ} \mathrm{C}$ and a pressure of $40 \mathrm{MPa}$ for $2 \mathrm{~h}$, the hexaaluminate was characterized by a relatively low Vickers hardness and bending strength compared to pure alumina, but exhibited a higher fracture toughness. The same authors also reported the synthesis of

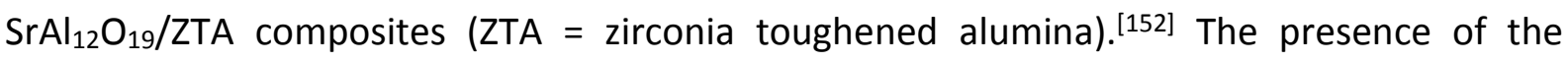
hexaaluminate favors the formation of plate-like grains and improves the fracture toughness.

\section{Future perspectives and conclusions}

Hexaaluminates have a structure that gives them remarkable resistance to sintering and thermal shock, thus meaning that the composition of the oxide phase can be maintained at a 
very high temperature. Aluminum cations can be partially or completely replaced by transition or noble metals, thereby giving rise to a variety of redox centers that can play an important role in the field of heterogeneous catalysis in the near future. These properties mean that hexaaluminates can be considered to be promising materials for many applications that require thermal resistance, such as combustion of $\mathrm{CH}_{4}$, partial oxidation of $\mathrm{CH}_{4}(\mathrm{POM})$, dry reforming of $\mathrm{CH}_{4}$ (DRM) and decomposition of $\mathrm{N}_{2} \mathrm{O}$.

In recent years, synthetic methods have been developed with the aim of increasing the textural properties of hexaaluminates, reaching specific surfaces of up to $160 \mathrm{~m}^{2} / \mathrm{g}$ after calcination at $1300{ }^{\circ} \mathrm{C}$. The starting values of these materials were in the range $10-20 \mathrm{~m}^{2} / \mathrm{g}$. To increase these values, the chemical homogeneity of the precursor has been enhanced and unconventional drying methods have been implemented. Thus, sol-gel, reverse microemulsion, hydrothermal synthesis, carbon-templating, solution combustion synthesis and freeze drying methods, amongst others, have been reported. However, further studies of the preparation stages of hexaaluminates are still required to enhance the textural properties and make these processes more sustainable in terms of the procedures and raw materials involved. The development of hexaaluminates with improved textural properties will allow these materials to broaden the spectrum of catalytic applications and to compete with other catalytic systems based on perovskites and spinels. Additionally, it must be taken into account that, with respect to other oxides, hexaaluminates have a structure and composition that allows them to form part of the monolithic honeycomb for gas turibine combustor without apparent loss of their catalytic properties.

Although the application of these materials is oriented towards heterogeneous catalysis, it will be necessary to increase the number of metals that can be stably introduced into the structure of the hexaaluminates and increase their dispersion, thus making the 
active centers more accessible. These two objectives will allow future lines of research to focus on optimizing metal/hexaaluminate structures. Additionally, since the hexaaluminate structure is obtained at high temperature, the loss of activity due to deactivation by coke deposition or loss of active metallic phases by regeneration and reuse will be reduced, making these oxides even more attractive in catalytic applications.

In conclusion, there are still several interesting areas to be explored as regards the application of hexaaluminates as thermal barriers and oxidation resistant coatings, especially given the fact that the particular structure of hexaaluminates means that they can be designed, controlled and adapted to desired applications. The synthesis of hexaaluminates from industrial metal wastes ${ }^{[153]}$ may be of relevant interest because close the cycle of new concepts in circular enconomy.

\section{Acknowledgements}

The authors are grateful for financial support from the Spanish Ministry of Economy, Industry and Competitiveness (AEI/MINECO), the European Regional Development Fund (ERDF) through project MAT2016-78863-C2-R. JJTH thanks Universidad Pública de Navarra for a pre-doctoral grant. AG also thanks Santander Bank for funding via the Research Intensification Program. 


\section{References}

1. M. Gasperin, M.C. Saine, A. Kahn, F. Laville, A.M. Lejus, Influence of $\mathrm{M}^{2+}$ ions substitution on the structure of lanthanum hexaaluminates with magnetoplumbite structure, J. Solid State Chem., 54, (1984), 61-69. https://doi.org/10.1016/00224596(84)90131-2

2. G. Groppi, C. Cristiani, P. Forzatti. Preparation and characterization of hexaaluminate materials for high-temperature catalytic combustion. 85-113. In: J.J. Spivey (ed) Catalysis, Vol. 13, The Royal Society of Chemistry.

3. H. Inoue, K. Sekizawa, K. Eguchi, H. Arai, Thick-film coating of hexaaluminate catalyst on ceramic substrates for high-temperature combustion, Catal. Today, 47, (1999), 181190. https://doi.org/10.1016/S0920-5861(98)00298-3

4. P. Forzatti, G. Groppi, Catalytic combustion for the production of energy, Catal. Today, 54, (1999), 165-180. https://doi.org/10.1016/S0920-5861(99)00178-9

5. A. Beretta, P. Forzatti, High-temperature and short-contact-time oxidative dehydrogenation of ethane in the presence of $\mathrm{Pt} / \mathrm{Al}_{2} \mathrm{O}_{3}$ and $\mathrm{BaMnAl}_{11} \mathrm{O}_{19}$ catalysts, J. Catal., 200, (2001), 45-58. https://doi.org/10.1006/icat.2001.3192

6. G. Groppi, L. Lietti, E. Tronconi, P. Forzatti, Catalytic combustion of gasified biomasses over Mn-substituted hexaaluminates for gas turbine applications, Catal. Today, 45, (1998), 159-165. https://doi.org/10.1016/S0920-5861(98)00270-3

7. S. Djambazov, A. Yoleva, Synthesis and properties of lanthanum hexaaluminate ceramic La $\mathrm{La}_{1-\mathrm{x}} \mathrm{Ca}_{x} \mathrm{Al}_{11-\mathrm{y}-\mathrm{M}} \mathrm{Mg}_{y} \mathrm{Ti}_{z} \mathrm{O}_{18}$, Ceramics Inter., 27, (2001), 899-901. https://doi.org/10.1016/S0272-8842(01)00049-9

8. M. Ashtar, Y.X. Gao, C.L. Wang, Y. Qiu, W. Tong, Y.M. Zou, X.W. Zhang, M.A. Marwat, S.L. Yuan, Z.M. Tian, Synthesis, structure and magnetic properties of rare-earth 
$\mathrm{REMgAl}_{11} \mathrm{O}_{19}(\mathrm{RE}=\mathrm{Pr}, \mathrm{Nd})$ compounds with two-dimensional triangular lattice, J. Alloys Comp. 802, (2019), 146-151. https://doi.org/10.1016/j.jallcom.2019.06.177

9. D. Gourier, F. Laville, D. Vivien, C. Valladas, X-ray induced defects and thermoluminescent properties of lanthanum hexaaluminates with magnetoplumbitelike structure, J. Solid State, Chem. 61, (1986), 67-80. https://doi.org/10.1016/00224596(86)90007-1

10. R.S. Roth, S. Hasko. Beta-alumina-type structure in the system lanthana-alumina. J. Am. Ceram. Soc. 41, (1958), 146-146. https://doi.org/10.1111/j.11512916.1958.tb13529.x

11. M. Machida, K. Eguchi, H. Arai. Effect of additives on the surface area of oxide supports for catalytic combustion. J. Catal. 103, (1987), 385-393. https://doi.org/10.1016/00219517(87)90129-1

12. Y. Zhu, X. Wang, A. Wang, G. Wu, J. Wang, T. Zhang, Identification of the chemical state of $\mathrm{Fe}$ in barium hexaaluminate using Rietveld refinement and ${ }^{57} \mathrm{Fe}$ Mössbauer $\begin{array}{llll}\text { spectroscopy, } \quad \text { J. } & \text { Catal., }\end{array}$ https://doi.org/10.1016/j.jcat.2011.08.001

13. J.-G. Park, A.N. Cormack. Crystal/defect structures and phase stability in Ba hexaaluminates, J. Solid State Chem. 121, (1996), 278-290. https://doi.org/10.1006/jssc.1996.0039

14. J.-G. Park, A.N. Cormack, Defect energetics and nonstoichiometry in lanthanum magnesium hexaaluminate, J. Solid State Chem., 130, (1997), 199-212. https://doi.org/10.1006/jssc.1996.7141 
15. J.-G. Park, A.N. Cormack. Defect structures and nonstoichiometry in lanthanum hexaaluminate, J. European Ceramic Soc. 19, (1999), 2249-2256. https://doi.org/10.1016/S0955-2219(99)00123-5

16. N. Iyi, Z. Inoue, S. Takekawa, S. Kimura, The crystal structure of barium hexaaluminate phase I (barium $\beta$-alumina), J. Solid State Chem., 52 (1984) 66-72. https://doi.org/10.1016/0022-4596(84)90199-3

17. N. Iyi, S. Takekawa, S. Kimura, Crystal chemistry of hexaaluminates: $\beta$-alumina and magnetoplumbite structures, J. Solid State Chem., 83 (1989) 8-19. https://doi.org/10.1016/0022-4596(89)90048-0

18. H. Inoue, K. Sekizawa, K. Eguchi, H. Arai, Changes of crystalline phase and catalytic properties by cation substitution in mirror plane of hexaaluminate compounds, J. Solid State Chem., 121 (1996) 190-196. https://doi.org/10.1006/jssc.1996.0027

19. Y. Zhu, X. Wang, G. Wu, Y. Huang, Y. Zhang, J. Wang, T. Zhang, Evolution of Fe crystallographic sites from Barium hexaaluminate to hexaferrite, J. Phys. Chem. C, 116, (2012), 671-680. https://doi.org/10.1021/jp2067414

20. Y. Zhang, X. Wang, Y. Zhu, X. Liu, T. Zhang, Thermal evolution crystal structure and Fe crystallographic sites in LaFe $\mathrm{Al}_{12-\mathrm{x}} \mathrm{O}_{19}$ hexaaluminates, J. Phys. Chem. C, 118, (2014), 10792-10804. https://doi.org/10.1021/jp500682d

21. M. Tian, X.D. Wang, T. Zhang. Hexaaluminates: a review of the structure, synthesis and catalytic performances. Catal. Sci. \& Technol. 6, (2016), 1984-2004. https://doi.org/10.1039/C5CY02077H

22. S. Chandra, Qualitative and kinetic study of the effect of barium chloride additions on the formation of barium monoaluminate and hexaaluminate, Amer. Ceram. Soc. Bull. 64, (1985), 1120-1123. 
23. S. Nugroho, Z.-C. Chen, A. Kawasaki, M.O.D. Jarligo, Solid-state synthesis and formation mechanism of barium hexaaluminate from mechanically activated $\mathrm{Al}_{2} \mathrm{O}_{3}-\mathrm{BaCO}_{3}$ powder $\begin{array}{lllll}\text { mixtures, J. } \quad \text { Alloys } & \text { (2010), 466-471. }\end{array}$ https://doi.org/10.1016/j.jallcom.2010.04.198

24. O.A. Kirichenko, O.V. Andrushkova, V.A. Ushakov, V.A. Poluboyarov, in Studies in Surface Science and Catalysis, G. Poncelet, J. Martens, B. Delmon, P.A. Jacobs, P. Garnge (eds), Elsevier, 91, (1995), 851.

25. S.R. Jansen, J.W. de Haan, L.J.M. van de Ven, R. Hanssen, H.T. Hintzen, R. Metselaar. Incorporation of nitrogen in alkaline-earth haxaaluminates with a $\beta$-alumina- or a magnetoplumbite-type structure, Chem. Mater., 9, (1997), 1516-1523. https://doi.org/10.1021/cm970109e

26. S. Laassiri, D. Duprez, S. Royer, H. Alamdari, Solvent free synthesis of nanocrystalline hexaaluminate-type mixed oxides with high specific surface areas for CO oxidation $\begin{array}{lllll}\text { reaction, } & \text { Catal. } & \text { Sci. } & \text { (2011), } & \text { 1124-1127. }\end{array}$ https://doi.org/10.1039/c1cy00211b

27. V. Doležal, L. Nádherný, K. Rubešová, V. Jakeš, A. Michalcová, O. Jankovský, M. Poupon, $\mathrm{LaMgAl}_{11} \mathrm{O}_{19}$ synthesis using non-hydrolytic sol-gel methods, Ceram. Inter., 45, (2019), 11233-11240. https://doi.org/10.1016/j.ceramint.2019.02.162

28. M. Machida, K. Eguchi, H. Arai, Catalytic properties of $\mathrm{BaMAl}_{11} \mathrm{O}_{19-\alpha}(\mathrm{M}=\mathrm{Cr}, \mathrm{Mn}, \mathrm{Fe}$, Co, and Ni) for high-temperature catalytic combustion, J. Catal., 120, (1989), 377-386. https://doi.org/10.1016/0021-9517(89)90277-7

29. M. Machida, K. Eguchi, H. Arai, Preparation and characterization of large surface area BaO-6 $\mathrm{Al}_{2} \mathrm{O}_{3}$, Bull. Chem. Soc. Jpn., 61, (1988), 3659-3665. 
30. M. Machida, A. Sato, M. Murakami, T. Kijima, H. Arai, Structure and catalytic property of coherent spinel surface layers on hexaaluminate microcrystals, J. Catal., 157, (1995), 713-720. https://doi.org/10.1006/jcat.1995.1337

31. K. Sekizawa, M. Machida, K. Eguchi, H. Arai. Catalytic properties of Pd-supported hexaaluminate catalysts for high-temperature catalytic combustion, J. Catal. 142, (1993), 655-663. https://doi.org/10.1006/jcat.1993.1238

32. R. Kikuchi, Y. Tanaka, K. Sasaki, K. Eguchi, High temperature catalytic combustion of methane and propane over hexaaluminate catalysts: NOx emission characteristics, Catal Today 83, (2003), 223-231. https://doi.org/10.1016/S0920-5861(03)00242-6

33. P. Artizzu, N. Guilhaume, E. Garbowski, Y. Brullé, M. Primet, Catalytic combustion of methane on copper-substituted barium hexaaluminates. Catal. Lett., 1998, 51, 69-75. https://doi.org/10.1023/A:1019032917062

34. H.R. Rezaie, R. Naghizadeh, F. Arianpour, R. Ghasemzadeh, S. Eslami. An evaluation on sol-gel chemical processing of refractory barium hexa aluminate fibrous structures. J. Ceramic Process. Res., 10, (2009), 148-151.

35. D. Naoufal, J.M. Millet, E. Garbowski, Y. Brulle, M. Primet, Synthesis, structure and catalytic properties of Fe-substituted barium hexaaluminates, Catal. Lett., 54, (1998), 141-148. https://doi.org/10.1023/A:1019004711495

36. J.C. Debsikbar, Synthesis and characterization of gel-derived barium hexa-aluminate, J. Mat. Sci. 24, (1989), 3565-3572. https://doi.org/10.1007/BF02385741

37. A. Douy, Polyacrylamide gel: an efficient tool for easy synthesis of multicomponent oxide precursors of ceramics and glasses, Int, J. Inorg. Mater., 3, (2001), 699-707. https://doi.org/10.1016/S1466-6049(01)00188-X 
38. S.I. Woo, S.K. Kang, J. M. Sohn, Effect of water content in the precursor solution on the catalytic property and stability of $\mathrm{Sr}_{0.8} \mathrm{La}_{0.2} \mathrm{MnAl}_{11} \mathrm{O}_{19}$ high-temperature combustion catalyst, Appl. Catal. B: Environmental, 18, (1998), 317-324. https://doi.org/10.1016/S0926-3373(98)00052-6

39. L.C. Yan, L.T. Thompson, Synthesis and characterization of aerogel-derived cationsubstituted barium hexaaluminates, Appl. Catal. A: General, 171, (1998), 219-228. https://doi.org/10.1016/S0926-860X(98)00059-3

40. J.G. Xu, Z.J. Tian, J.W. Wang, Y.P. Xu, Z.S. Wu, L.W. Lin, Effect of drying methods on the structure and catalytic combustion activity of Mn-substituted hexaaluminate catalysts, $\begin{array}{llll}\text { React. Kinet. } & \text { Catal. }\end{array}$ https://doi.org/10.1023/B:REAC.0000028800.54308.88

41. S.J. Cho, Y.S. Seo, K.S. Song, N.J. Jeong, S.K. Kang, Surfactant-mediated synthesis of meal substituted hexaaluminate from alumina sol, Appl. Catal. B: Enviromental, 30, (2001), 351-357. https://doi.org/10.1016/S0926-3373(00)00247-2

42. P. Jana, P.S. Jayan, S. Mandal, K. Biswas, Effect of seeding on the formation of lanthanum hexaaluminates synthesized through advanced sol gel process, J. Cryst. Growth, 408, (2014), 7-13. http://dx.doi.org/10.1016/j.jcrysgro.2014.09.015

43. G. Groppi, M. Bellotto, C. Cristiani, P. Forzatti, P.L. Villa. Preparation and characterization of hexaaluminate-based materials for catalytic combustion. Applied Catalysis A: General. 104, (1993), 101-108. https://doi.org/10.1016/0926$860 \times(93) 85092-4$

44. G. Groppi, M. Belloto, C. Cristiani, P. Forzatti, P.L. Villa. Thermal evolution crystal structure and cation valence of $\mathrm{Mn}$ in substituted $\mathrm{Ba}-6-\mathrm{Al}_{2} \mathrm{O}_{3}$ prepared via 
coprecipitation in aqueous medium. J. Mater. Sci. 34, (1999), 2609-2620. https://doi.org/10.1023/A:1004604800540

45. G. Groppi, F. Assandri, M. Bellotto, C. Cristiani, P. Forzatti. The crystal structure of Ba$\beta$-alumina materials for hifh-temperature catalytic combustion. J. Solid State Chem., 114, (1995), 326-336. https://doi.org/10.1006/jssc.1995.1051

46. B.W.L. Jang, R.M. Nelson, J.J. Spivey, M. Ocal, R. Oukaci, G. Marcelin, Catalytic oxidation of methane over hexaaluminates and hexaaluminate-supported Pd catalysts. Catal. Today, 1999, 47, 103-113. https://doi.org/10.1016/S0920-5861(98)00288-0

47. J. Wang, Z. Tian, J. Xu, Y. Xu, Z. Xu, L. Lin. Preparation of Mn substituted Lahexaaluminate catalysts by using supercritical drying, Catal. Today 83, (2003), 213-222. https://doi.org/10.1016/S0920-5861(03)00238-4

48. A.J. Zarur, N.Z. Mehenti, A.T. Heibel, J.Y. Ying, Phase behavior, structure, and aplications of reverse microemulsions stabilized by nonionic surfactants, Langmuir, 16, (2000), 9168-9176. https://doi.org/10.1021/la9914880

49. A.J. Zarur, H.H. Hwu, J.Y. Ying, Reverse microemulsion-mediated synthesis and structural evolution of barium hexaaluminate nanoparticles, Langmuir, 16, (2000), 3042-3049. https://doi.org/10.1021/la9908034

50. A.J. Zarur, J.Y. Ying. Reverse microemulsion synthesis of nanostructured complex oxides for catalytic combustion, Nature 403, (2000), 65-67. https://doi.org/10.1038/47450

51. P.K. Sahu, B.D. Kulkarni, R.B. Khomane, S.A. Pardhy, U.D. Phalgune, P. Rajmohanan, R. Pasricha, Barium hexaaluminate nanowhiskers synthesized by novel sol-gel process in reverse micellar media, Chem. Commun., (2003), 1876-1877. http://www.rsc.org/suppdata/cc/b3/b303815g 
52. F. Teng, J. Xu, Z. Tian, J. Wang, Y. Xu, Z. Xu, G. Xiong, L. Lin, Formation of a novel type of reverse microemulsion system and its application in synthesis of the nanostructured La0.95 $\mathrm{Ba}_{0.05} \mathrm{MnAl}_{11} \mathrm{O}_{19} \quad$ catalyst, Chem. Commun., (2004), 1858-1859. http://www.rsc.org/suppdata/cc/b4/b404133j

53. F. Teng, Z. Xu, G. Xiong, Y. Xu, Z. Xu, L. Lin. Synthesis of the high-surface-area $\mathrm{Ce}_{x} \mathrm{Ba}_{1-x} \mathrm{MnAl}_{11} \mathrm{O}_{y}$ catalyst in reverse microemulsions using inexpensive inorganic salts as precursors. Green Chemistry 7, (2005), 493-499. https://doi.org/10.1039/b417229a

54. Z. Jiang, Z. Hao, J. Su, T. Xiao, P.P. Edwards, Water/oil microemulsion for the preparation of robust La-hexaaluminates for methane catalytic combustion, Chem. Commun. (2009), 3225-3227. https://doi.org/10.1039/b900012g

55. Z. Wang, Z. Cai, Z. Wei, Highly active ruthenium catalyst supported on barium hexaaluminate for ammonia decomposition to $\mathrm{CO}_{\mathrm{x}}-$ free hydrogen, ACS Sustainable Chem. Eng., 7, (2019), 8226-8235. https://doi.org/10.1021/acssuschemeng.8b06308

56. K. Zhang, G. Zhou, J. Li, K. Zhen, T. Cheng, Effective additives of A(Ce, Pr) in modified hexaaluminate $\mathrm{La}_{x} \mathrm{~A}_{1-x} \mathrm{NiAl}_{11} \mathrm{O}_{19}$ for carbon dioxide reforming of methane, Catal. Lett., 130, (2009), 246-253. https://doi.org/10.1007/s10562-009-9876-3

57. K. Zhang, G. Zhou, J. Li, T. Cheng, The electronic effects of $\operatorname{Pr}$ on $\mathrm{La}_{1-\mathrm{x}} \mathrm{Pr}_{\mathrm{x}} \mathrm{NiAl}_{11} \mathrm{O}_{19}$ for $\mathrm{CO}_{2}$ reforming of methane, Catal. Commun., 10, (2009), 1816-1820. https://doi.org/10.1016/j.catcom.2009.06.007

58. Y. Liu, T.X. Cheng, D.M. Li, P.B. Jiang, J.X. Wang, W.X. Li, Y.L. Bi, K.J. Zhen, Studies on the stability of a $\mathrm{La}_{0.8} \mathrm{Pr}_{0.2} \mathrm{NiAl}_{11} \mathrm{O}_{19}$ catalyst for syngas production by $\mathrm{CO}_{2}$ reforming of methane, Catal. Lett., 85, (2003), 101-107. https://doi.org/10.1023/A:1022181110569

59. Y. Liu, Z. L. Xu, T. X. Cheng, G.D. Zhou, J.X. Wang, W.X. Li, Y.L. Bi, K.J. Zhen, Studies on carbon deposition on hexaaluminate $\mathrm{LaNiAl}_{11} \mathrm{O}_{19}$ catalysts during $\mathrm{CO}_{2}$ reforming of 
$\begin{array}{llll}\text { methane, } \quad \text { Kinet. } & \text { Catal., } & \text { 43, }\end{array}$ https://doi.org/10.1023/A:1019879018935

60. W.L. Chu, W.S. Yang, L.W. Lin, The partial oxidation of methane to syngas over the nickel-modified hexaaluminate catalysts $\mathrm{BaNi}_{y} \mathrm{Al}_{12-\mathrm{y}} \mathrm{O}_{19-\delta}, \mathrm{Appl}$. Catal. A: General, 235, (2002), 39-45. https://doi.org/10.1016/S0926-860X(02)00240-5

61. Z.L. Xu, M. Zhen, Y.L. Bi, K.J. Zhen, Carbon dioxide reforming of methane to synthesis gas over hexaaluminate $\mathrm{ANiAl}_{11} \mathrm{O}_{19-\delta}(\mathrm{A}=\mathrm{Ca}, \mathrm{Sr}, \mathrm{Ba}$ and $\mathrm{La})$ catalysts. Catal. Lett., 64, (2000), 64, 157-161. https://doi.org/10.1023/A:1019039004361

62. Z.L. Xu, M. Zhen, Y.L. Bi, K. J. Zhen, Catalytic properties of Ni modified hexaaluminates $\mathrm{LaNi}_{y} \mathrm{Al}_{12-y} \mathrm{O}_{19-\delta}$ for $\mathrm{CO}_{2}$ reforming of methane to synthesis gas. Appl. Catal. A: General, 198, (2000), 267-273. https://doi.org/10.1016/S0926-860X(99)00518-9

63. J.G. Xu, Z.J. Tian, J.W. Wang, Y.P. Xu, Z.S. Xu, L.W. Lin, Hydrothermal synthesis of LaMn-hexaaluminates for the catalytic combustion of methane, Korean J. Chem. Eng., 20, (2003), 217-221.

64. D. Mishra, S. Anand, R.K. Panda, R.P. Das. Preparation of barium hexa-aluminate through a hydrothermal precipitation-calcination route and characterization of intermediate and final products. Mater. Letters, 56, (2002), 873-879. https://doi.org/10.1016/S0167-577X(02)00630-4

65. B. Djuricic, S. Pickering, D. Mcgarry, Preparation and properties of alumina-baria nano$\begin{array}{lllll}\text { composites, J. } & \text { Mater. }\end{array}$ https://doi.org/10.1023/A:1004625405083

66. J. Gao, C. Jia, M. Zhang, F. Gu, G. Xu, Z. Zhong, F. Su, Template preparation of highsurface-area barium hexaaluminate as nickel catalyst support for improved CO 
methanation, RSC Advances, 3, (2013), 18156-18163. https://doi.org/10.1039/c3ra41660g

67. M. Santiago, J. C. Groen, J. Perez-Ramirez, Carbon-templated hexaaluminates with enhanced surface area and catalytic performance. J. Catal. 257, (2008), 152-162. https://doi.org/10.1016/j.jcat.2008.04.017

68. L.A. Schulz, L.C.S. Kahle, K. Herrera Delgado, S.A. Schunk, A. Jentys, O. Deutschmann, J.A. Lercher, On the coke deposition in dry reforming of methane at elevated pressures, Appl. Catal. A: $\quad$ (2015), 599-607. https://doi.org/10.1016/j.apcata.2015.03.002

69. T. Roussiere, L. Schulz, K.M. Schelkle, G. Wasserschaff, A. Milanov, E. Schwab, O. Deutschmann, A. Jentys, J. Lercher, S.A. Schunk, Structure-activity relationships of nickel-hexaaluminates in reforming reactions part II: activity and stability of nanostructured nickel-hexaaluminate-based catalysts in the dry reforming of methane, Chemcatchem, 6, (2014), 1447-1452. https://doi.org/10.1002/cctc.201300958

70. T. Roussiere, K.M. Schelkle, S. Titlbach, G. Wasserschaff, A. Milanov, G. Cox, E. Schwab, O. Deutschmann, L. Schulz, A. Jentys, J. Lercher, S.A. Schunk, Structure-activity relationships of nickel-hexaaluminates in reforming reactions Part I: controlling nickel nanoparticle growth and phase formation, Chemcatchem, 6, (2014), 1438-1446. https://doi.org/10.1002/cctc.201300960

71. S. Cimino, R. Nigro, U. Weidmann, R. Holzner, Catalytic combustion of methanol over La, Mn-hexaaluminate catalysts, Fuel Process. Technol. 133, (2015), 1-7. http://dx.doi.org/10.1016/j.fuproc.2014.12.047.

72. P. Xu, X. Zhang, X. Zhao, J. Yang, Z. Hou, L. Bai, H. Chang, Y. Liu, J. Deng, G. Guo, H. Dai, Ch.-T. Au, Preparation, characterization, and catalytic performance of PdPt/3DOM 
LaMnAl $_{11} \mathrm{O}_{19}$ for the combustion of methane, Appl. Catal. A: General, 562, (2018), 284293. https://doi.org/10.1016/j.apcata.2018.05.022

73. M. Kustova, K. Egeblad, K. Zhu, C.H. Christensen. Versatile route to zeolite single crystals with controlled mesoporosity: in situ sugar decomposition for templating of hierarchical zeolites. Chem. Mater. 19, (2007), 2915-2917. https://doi.org/10.1021/cm071168n

74. M. Schwickardi, T. Johann, W. Schmidt, F. Schüth. High-surface-area oxides obtained by an activated carbon route. Chem. Mater. 14, (2002), 3913-3919. https://doi.org/10.1021/cm0211857

75. M. Bellotto, G. Artioli, C. Cristiani, P. Forzatti, G. Groppi, On the Crystal Structure and Cation Valence of $\mathrm{Mn}$ in $\mathrm{Mn}$-Substituted $\mathrm{Ba}-\mathrm{\beta}_{-} \mathrm{Al}_{2} \mathrm{O}_{3}$, J. Catal., 179, (1998), 597-605. https://doi.org/10.1006/jcat.1998.2220

76. B.M.J. Smets, J.G. Verlijsdonk. The luminescence properties of $\mathrm{Eu}^{2+}$ - and $\mathrm{Mn}^{2+}$-doped barium hexaaluminates, Mater. Res. Bull., 21, (1986), 1305-1310. https://doi.org/10.1016/0025-5408(86)90065-6

77. P. Artizzu-Duart, J.M. Millet, N. Guilhaume, E. Garbowski, M. Primet, Catalytic combustion of methane on substituted barium hexaaluminates, Catal. Today, 59, (2000), 163-177. https://doi.org/10.1016/S0920-5861(00)00281-9

78. P. Artizzu-Duart, Y. Brulle, F. Gaillard, N. Guilhaume, M. Primet, Catalytic combustion of methane over copper- and manganese-substituted barium hexaaluminates, Catal. Today, 54, (1999), 181-190. https://doi.org/10.1016/S0920-5861(99)00179-0

79. G. Groppi, C. Cristiani, P. Forzatti, Preparation, characterisation and catalytic activity of pure and substituted La-hexaaluminate systems for high temperature catalytic 
combustion. Appl. Catal. B: Environmental, 35, (2001), 137-148. https://doi.org/10.1016/S0926-3373(01)00248-X

80. T. Li, Y. Li, Effect of magnesium substitution into $\mathrm{LaMnAl}_{11} \mathrm{O}_{19}$ haxaaluminate on the activity of methane catalytic combustion, Ind. Eng. Chem. Res., 47, (2008), 1404-1408. https://doi.org/10.1021/ie070606x

81. S. Li and X. Wang, Catalytic combustion of methane over Mn-substituted Ba-Lahexaaluminate nanoparticles, J. Alloys Compd., 432, (2007), 333-337. https://doi.org/10.1016/j.jallcom.2006.06.022

82. G. Groppi, C. Cristiani, P. Forzatti, $\mathrm{BaFe}_{x} \mathrm{Al}_{(12-\mathrm{x})} \mathrm{O}_{19}$ system for high-temperature catalytic combustion: physico-chemical characterization and catalytic activity, J. Catal., 168, (1997), 95-103. https://doi.org/10.1006/jcat.1997.1632

83. S. Laassiri, N. Bion, D. Duprez, H. Alamdari, S. Royer, Role of $\mathrm{Mn}^{+}$cations in the redox and oxygen transfer properties of $\mathrm{BaM}_{x} \mathrm{Al}_{12-\mathrm{x}} \mathrm{O}_{19-\delta}(\mathrm{M}=\mathrm{Mn}, \mathrm{Fe}, \mathrm{Co})$ nanomaterials for high temperature methane oxidation, Catal. Sci. Technol., 3, (2013), 2259-2269. https://doi.org/10.1039/С3CY00192J

84. L. Lietti, C. Cristiani, G. Groppi, P. Forzatti, Preparation, characterization and reactivity of Me-hexaaluminate ( $\mathrm{Me}=\mathrm{Mn}, \mathrm{Co}, \mathrm{Fe}, \mathrm{Ni}, \mathrm{Cr}$ ) catalysts in the catalytic combustion of $\mathrm{NH}_{3}$-containing gasified biomasses, Catal. Today, 59, (2000), 191-204. https://doi.org/10.1016/S0920-5861(00)00283-2

85. A. Ersson, K. Persson, I.K. Adu, S.G. Jaras, A comparison between hexaaluminates and perovskites for catalytic combustion applications, Catal. Today, 112, (2006), 157-160. https://doi.org/10.1016/j.cattod.2005.11.024

86. S.G. Lee, H. Lee, C.H. Lee, J.Y. Kwon, H.C. Park, S.S. Hong, S.S. Park, Synthesis and catalytic properties of barium hexaaluminates incorporated with chromium and 
lanthanum, React. Kinet. Catal. Lett., 86, (2005), 299-306. https://doi.org/10.1007/s11144-005-0325-z

87. F. Teng, Y. Man, S. Liang, G. Buergen, Y. Zhu, W. Han, P. Xu, G. Xiong, Z. Tian, Crystal structure stability and catalytic activity of magnetoplumbite (MP) catalyst doped with Mn and Mg, J. Non-Cryst. Solids, 353, (2007), 4806-4812. https://doi.org/10.1016/j.jnoncrysol.2007.06.069

88. M. Astier, E. Garbowski, M. Primet, $\mathrm{BaMgAl}_{10} \mathrm{O}_{17}$ as hot matrix for $\mathrm{Mn}$ in the catalytic combustion of methane, Catal. Lett., 95, (2004), 31-37. https://doi.org/10.1023/B:CATL.0000023718.79151.3a

89. K. Ikkour, D. Sellam, A. Kiennemann, S. Tezkratt, O. Cherifi, Activity of Ni substituted Ca-La-hexaaluminate catalyst in dry reforming of methane, Catal. Letters 132, (2009), 213-217. https://doi.org/10.1007/s10562-009-0094-9

90. T.H. Gardner, J.J. Spivey, E.L. Kugler, A. Campos, J.C. Hissam, A.D. Roy, Structural characterization of Ni-substituted hexaaluminate catalysts using EXAFS, XANES, XPS, XRD, and TPR, J. Phys. Chem. C, 114, (2010), 7888-7894. https://doi.org/10.1021/jp9117634

91. R. Kikuchi, Y. Iwasa, T. Takeguchi, K. Eguchi, Partial oxidation of $\mathrm{CH}_{4}$ and $\mathrm{C}_{3} \mathrm{H}_{8}$ over hexaaluminate-type oxides, Appl. Catal. A: General, 281, (2005), 61-67. https://doi.org/10.1016/j.apcata.2004.11.013

92. S. Zhu, X. Wang, A. Wang, Y. Cong, T. Zhang, A novel Ir-hexaaluminate catalyst for $\mathrm{N}_{2} \mathrm{O}$ as a propellant, Chem. Commun., (2007), 1695-1697. https://doi.org/10.1039/B702502E 
93. S. Zhu, X. Wang, A. Wang, T. Zhang, Superior performance of Ir-substituted hexaaluminate catalysts for $\mathrm{N}_{2} \mathrm{O}$ decomposition, Catal. Today, 131, (2008), 339-346. https://doi.org/10.1016/j.cattod.2007.10.093

94. K. Sekizawa, K. Eguchi, H. Widjaja, M. Machida, H. Arai, Property of Pd-supported catalysts for catalytic combustion, Catal. Today, 28, (1996), 245-250. https://doi.org/10.1016/0920-5861(95)00241-3

95. M. Öcal, R. Oukaci, G. Marcelin, B.W.-L. Jang, J.J. Spivey. Steady-state isotopic transient kinetic analysis on Pd-supported hexaaluminates used for methane combustion in the presence and absence of NO. Catal. Today, 59, (2000), 205-217. https://doi.org/10.1016/S0920-5861(00)00284-4

96. J.M. Sohn, S.K. Kang, S.I. Woo, Catalytic properties and characterization of Pd supported on hexaaluminate in high temperature combustion, J. Mol. Catal. A: Chem., 186, (2002), 135-144. https://doi.org/10.1016/S1381-1169(02)00067-5

97. A. Baylet, S. Royer, R. Marecot, J. M. Tatibouet, D. Duprez, High catalytic activity and stability of $\mathrm{Pd}$ doped hexaaluminate catalysts for the $\mathrm{CH}_{4}$ catalytic combustion, Appl. $\begin{array}{llll}\text { Catal. } & \text { B: } & \text { Environmental, 237-247. }\end{array}$ https://doi.org/10.1016/j.apcatb.2007.07.031

98. A. Baylet, S. Royer, C. Labrugere, H. Valencia, P. Marecot, J.M. Tatibouet, D. Duprez, Effect of palladium on the reducibility of $\mathrm{Mn}$ based materials: correlation with methane oxidation activity, Phys. Chem. Chem. Phys., 10, (2008), 5983-5992. https://doi.org/10.1039/b808289h

99. S. A. Yashnik, Z. R. Ismagilov, The nature of synergetic effect of manganese oxide and platinum in Pt-MnOx-alumina oxidation catalysts, Top. Catal., 55, (2012), 818-836. https://doi.org/10.1007/s11244-016-0722-8 
100. A. Baylet, S. Royer, P. Marecot, J. M. Tatibouet, D. Duprez, Effect of Pd precursor salt on the activity and stability of Pd-doped hexaaluminate catalysts for the $\mathrm{CH}_{4}$ catalytic combustion, Appl. Catal. B: Environmental, 81, (2008), 88-96. https://doi.org/10.1016/j.apcatb.2007.12.004

101. M. Machida, K. Eguchi, H. Arai, Effect of structural modification on the catalytic property of Mn-substituted hexaaluminates, J. Catal., 123, (1990), 477-485. https://doi.org/10.1016/0021-9517(90)90144-9

102. M. Machida, A. Sato, T. Kijima, H. Inoue, K. Eguchi, H. Arai, Catalytic properties and surface modification of hexaaluminate microcrystals for combustion catalyst, Catal. Today, 26, (1995), 239-245. https://doi.org/10.1016/0920-5861(95)00145-3

103. S. Laassiri, N. Bion, D. Duprez, S. Royer, H. Alamdari, Clear microstructureperformance relationships in Mn-containing perovskite and hexaaluminate compounds prepared by activated reactive synthesis, Phys. Chem. Chem. Phys., 16, (2014), 40504060. https://doi.org/10.1039/c3cp54363c

104. R.W. Sidwell, H. Zhu, B.A. Kibler, R.J. Kee, D.T. Wickham, Experimental investigation of the activity and thermal stability of hexaaluminate catalysts for lean methane-air combustion, Appl. Catal. A: General, 255, (2003), 279-288. https://doi.org/10.1016/S0926-860X(03)00566-0

105. S.A. Yashnik, Z.R. Ismagilov, Dependence of synergetic effect of palladium-manganesehexaaluminate combustion catalyst on nature of palladium precursor, Topics Catal. 55, (2012), 818-836. https://doi.org/10.1007/s11244-012-9874-3

106. X. Li, Y. Liu, J. Deng, Y. Zhang, S. Xie, X. Zhao, Z. Wang, G. Guo, H. Dai, 3DOM LaMnAl ${ }_{11} \mathrm{O}_{19}$-supported AuPd alloy nanoparticles: Highly active catalysts for methane 
combustion in a continuous-flow microreactor. Catal. Today, 308, (2018), 71-80. http://dx.doi.org/10.1016/j.cattod.2017.07.024

107. N.E. McGuire, N.P. Sullivan, O. Deutschmann, H. Zhu, R.J. Kee, Dry reforming of methane in a stagnation-flow reactor using Rh supported on strontium-substituted hexaaluminate, Appl. Catal. A: General, 394, (2011), 257-265. https://doi.org/10.1016/j.apcata.2011.01.009

108. W.L. Chu, W.S. Yang, L.W. Lin, Selective oxidation of methane to syngas over NiO/barium hexaaluminate, Catal. Lett., 74, (2001), 139-144. https://doi.org/10.1023/A:1016622301743

109. Y. Liu, Z. Xu, T. Cheng, G. Zhou, J. Wang, W. Li, Y. Bi, K. Zhen, Studies on carbon deposition on hexaaluminate $\mathrm{LaNiAl}_{11} \mathrm{O}_{19}$ catalysts during $\mathrm{CO}_{2}$ reforming of methane, Kin. Catal., 43, (2002), 522-527. https://doi.org/10.1023/A:1019879018935

110. W. L. Chu, W. S. Yang and L. W. Lin, The partial oxidation of methane to syngas over the nickel-modified hexaaluminate catalysts $\mathrm{BaNi}_{y} \mathrm{Al}_{12-y} \mathrm{O}_{19-\delta}$, Appl. Catal. A: General, 2002, 235, 39-45. https://doi.org/10.1016/S0926-860X(02)00240-5

111. T. Utaka, S. A. Al-Drees, J. Ueda, Y. Iwasa, T. Takeguchi, R. Kikuchi, K. Eguchi, Partial oxidation of methane over $\mathrm{Ni}$ catalysts based on hexaaliminate- or perovskite-type oxides, Appl. Catal. A: General, 247, (2003), 125-131. https://doi.org/10.1016/S0926$860 \times(03) 00129-7$

112. J. Gao, Ch. Jia, J. Li, F. Gu, G. Xu, Z. Zhong, F. Su, Nickel catalysts supported on barium hexaaluminate for enhanced CO methanation, Ind. Eng. Chem. Res., 51, (2012), 1034510353. https://doi.org/10.1021/ie300566n 
113. L. Majocchi, H. Croppi, C. Cristiani, P. Forzatti, L. Basini, A. Guarinoni, Partial oxidation of methane to synthesis gas over Rh-hexaaluminate-based catalysts, Catal. Letters, 65, (2000), 49-56. https://doi.org/10.1023/A:1019092516173

114. M. Tian, X. Wang, X. Liu, A. Wang, T. Zhang, Fe-substituted Ba-hexaaluminates oxygen carrier for carbon dioxide capture by chemical looping combustion of methane, AIChE J, 62, (2016), 792-801. https://doi.org/10.1002/aic.15135

115. F. Huang, M. Tian, Y. Zhu, X. Wang, A. Wang, L. Li, J. Lin, J. Wang, Fe-substituted Bahexaaluminate with enhanced oxygen mobility for $\mathrm{CO}_{2}$ capture by chemical looping combustion of methane, J. Energy Chem., 29, (2019), 50-57. https://doi.org/10.1016/j.jechem.2018.02.003

116. Q. Shen, F. Huang, M. Tian, Y. Zhu, L. Li, J. Wang, X. Wang, Effect of regeneration period on the selectivity of synthesis gas of Ba-hexaaluminates in chemical looping partial oxidation of methane, ACS Catal., 9, (2019), 722-731. https://doi.org/10.1021/acscatal.8b03855

117. Y. Zhu, R. Liu, X. Sun, X. Ma, X. Wang, H. Tian, Metal modified hexaaluminates for syngas generation and $\mathrm{CO}_{2}$ utilization via chemical looping, Int. J. Hydrogen Energy, 44, (2019), 10218-10231. https://doi.org/10.1016/j.ijhydene.2019.02.187

118. T.H. Gardner, J.J. Spivey, E.L. Kugler, D. Pakhare, $\mathrm{CH}_{4}-\mathrm{CO}_{2}$ reforming over Nisubstituted barium hexaaluminate catalysts, Appl. Catal. A: General, 455, (2013), 129136. https://doi.org/10.1016/j.apcata.2013.01.029

119. C. Garapon, L. Lou, R. Moncorge, Site-selective spectroscopy of $\mathrm{Nd}^{3+}$ in lanthanum magnesium hexaaluminate $\mathrm{LaMgAl}_{11} \mathrm{O}_{19}$ single crystals, J. Lumin., 79, (1998), 161-175. https://doi.org/10.1016/S0022-2313(98)00032-5 
120. Y. Zhu, N. Jin, R. Liu, X. Sun, L. Bai, H. Tian, X. Ma, X. Wang, Bimetallic $\mathrm{BaFe}_{2} \mathrm{MAl}_{9} \mathrm{O}_{19}$ $(\mathrm{M}=\mathrm{Mn}, \mathrm{Ni}$, and $\mathrm{Co})$ hexaaluminates as oxygen carriers for chemical looping dry reforming of methane, Appl. Energy, 258, (2020), 114070. https://doi.org/10.1016/j.apenergy.2019.114070

121. C.P.B. Quitete, R.C.P. Bittencourt, M.M.V.M. Souza, Steam reforming of tar using toluene as a model compound with nickel catalysts supported on hexaaluminates, Appl. Catal. A: General, 478, (2014), 234-240. http://dx.doi.org/10.1016/j.apcata.2014.04.019

122. M.V. Bukhtiyarova, A.S. Ivanova, E.M. Slavinskaya, P.A. Kuznetsov, L.M. Plyasova, O.A. Stonkus, V.A. Rogov, V.V. Kaichev, A.S. Noskov, Steam reforming of methane over Nisubstituted Sr hexaaluminates, Catalysis for Sustainable Energy, (2013), 11-21. https://doi.org/10.2478/cse-2012-0002

123. M. Santiago, J. Perez-Ramirez, Decomposition of $\mathrm{N}_{2} \mathrm{O}$ over hexaaluminate catalysts, Environ. Sci. Technol., 41, (2007), 1704-1709. https://doi.org/10.1021/es061894b

124. M. Santiago, M.A.G. Hevia, J. Perez-Ramirez, Evaluation of catalysts for $\mathrm{N}_{2} \mathrm{O}$ abatement in fluidized-bed combustion, Appl. Catal. B: Environmental, 90, (2009), 83-88. https://doi.org/10.1016/j.apcatb.2009.02.017

125. E.V. Kondratenko, V.A. Kondratenko, M. Santiago, J. Perez-Ramirez, Mechanism and micro-kinetics of direct $\mathrm{N}_{2} \mathrm{O}$ decomposition over $\mathrm{BaFeAl}_{11} \mathrm{O}_{19}$ hexaaluminate and comparison with Fe-MFI zeolites, Appl. Catal. B: Environmental, 99, (2010), 66-73. https://doi.org/10.1016/j.apcatb.2010.05.033

126. J. Perez-Ramirez, M. Santiago, Metal-substituted hexaaluminates for high-temperature $\mathrm{N}_{2} \mathrm{O}$ abatement, Chem. Commun., (2007), 619-621. https://doi.org/10.1039/B613602H 
127. L. Lietti, C. Ramella, G. Groppi, P. Forzatti, Oxidation of $\mathrm{NH}_{3}$ and $\mathrm{NO}_{\mathbf{x}}$ formation during the catalytic combustion of gasified biomasses fuels over Mn-hexaaluminate and alumina-supported Pd catalysts, Appl. Catal. B: Enviromental, 21, (1999), 89-101. https://doi.org/10.1016/S0926-3373(99)00005-3

128. L. Lietti, G. Groppi, C. Ramella, $\mathrm{NH}_{3}$ oxidation during the catalytic combustion of biomasses-related fuels over Mn-substituted hexaaluminates, Catal. Letters, 53, (1998), 91-95. https://doi.org/10.1023/A:1019001821547

129. Y. Zhang, X. Wang, Y. Zhu, T. Zhang, Stabilization mechanism and crystallographic sites of $\mathrm{Ru}$ in Fe-promoted barium hexaaluminate under high-temperature condition for $\mathrm{N}_{2} \mathrm{O}$ decomposition, Appl. Catal. B: Environmental, 129, (2013), 382-393. https://doi.org/10.1016/j.apcatb.2012.10.001

130. M. Tian, A. Wang, X. Wang, Y. Zhu, T. Zhang, Effect of large cations $\left(\mathrm{La}^{3+}\right.$ and $\mathrm{Ba}^{2+}$ ) on the catalytic performance of $\mathrm{Mn}$-substituted hexaaluminates for $\mathrm{N}_{2} \mathrm{O}$ decomposition, $\begin{array}{lllll}\text { Appl. Catal. } & \text { B: } & \text { Environmental, } & \text { 92, }\end{array}$ https://doi.org/10.1016/j.apcatb.2009.09.002

131. S. Hong, S. Heo, W. Kim, Y.M. Jo Y.-K. Park, J.-K. Jeon, Catalytic decomposition of an energetic ionic liquid solution over hexaaluminate catalysts, Catalysts, 9, (2019), 80. https://doi.org/10.3390/catal9010080

132. Ch. Parsland, A.-Ch. Larsson, P. Benito, G. Fornasari, J. Brandin, Nickel-substituted bariumhexaaluminates as novel catalysts in steam reforming of tars. Fuel Proces. Technol. 140, (2015), 1-11. https://doi.org/10.1016/j.fuproc.2015.07.024

133. C. Quitete, R. Bittencourt, M. Souza. Steam reforming of tar model compound over nickel catalysts supported on barium hexaaluminate. Catal. Lett. 145, (2015), 541-548. https://doi.org/10.1007/s10562-014-1405-3 
134. G. Jiang, X. Zhang, F. Zhang, Z. Liu, Z. Wang, Z. Hao, C. Lin, Efficient recovery of hydrogen and sulfur resources over non-sulfide based $\mathrm{LaFe}_{x} \mathrm{Al}_{12-\mathrm{x}} \mathrm{O}_{19}$ hexaaluminate catalysts by $\mathrm{H}_{2} \mathrm{~S}$ catalytic decomposition, Appl. Catal. B: Environmental, 263, (2020), 118354. https://doi.org/10.1016/j.apcatb.2019.118354

135. T.H. Gardner, Syngas production over $\mathrm{La}_{0.9} \mathrm{Ni}_{y} \mathrm{Al}_{11.95-\mathrm{y}} \mathrm{O}_{19-\delta}$ catalysts during $\mathrm{C}_{14}$-alkane partial oxidation: Effects of sulfur and polycyclic aromatic hydrocarbons, Appl. Catal. A: General, 555, (2018), 118-129. https://doi.org/10.1016/j.apcata.2018.02.006

136. A. Bohre, U. Novak, M. Grilc, B. Likozar, Synthesis of bio-based methacrylic acid from biomass-derived itaconic acid over barium hexa-aluminate catalyst by selective decarboxylation reaction, Molec. Catal., 476, (2019), 110520. https://doi.org/10.1016/j.mcat.2019.110520.

137. H. Ai, H. Yang, Q. Liu, G. Zhao, J. Yang, F. Gu, $\mathrm{ZrO}_{2}$-modified Ni/LaAl ${ }_{11} \mathrm{O}_{18}$ catalyst for CO methanation: Effects of catalyst structure on catalytic performance, Chinese J. Catal., 39, (2018), 297-308. https://doi.org/10.1016/S1872-2067(17)62995-4

138. D. Wichham, R. Cook, Oxidation catalysts comprising metal exchanged hexaaluminate wherein the metal is Sr, Pd, La, and/or Mn, US Patent 7,442,669 B2 (2008).

139. S. Schunk, A. Milanov, A. Strasser, G. Wasserschuff and T. Roussiere, Hexaaluminatecomprising catalyst for the reforming of hydrocarbons and a reforming process, US Patent 2014/0191449 A1 (2014).

140. M.S. Ferrandon, Novel formulation of hexa-aluminates for reforming fuels, US Patent 2013/0085062 A1 (2013).

141. R. Gadow, M. Lischka, Lanthanum hexaaluminate-novel thermal barrier coatings for gas turbine applications-materials and process development, Surf. Coatings Technol., 151-152, (2002), 392-399. https://doi.org/10.1016/S0257-8972(01)01642-5 
142. R.R. Rao, L. Mariappan, Combustion synthesis and characterization of lanthanum hexaaluminate, Adv. Appl. Ceram., 104, (2005), 268-271. https://doi.org/10.1179/174367605X62427

143. L. Haoran, W. Chang-An, Z. Chenguang, T. Shuyan, Thermo-physical properties of rareearth hexaaluminates $\mathrm{LnMgAl}_{11} \mathrm{O}_{19}$ ( $\mathrm{Ln}$ : $\mathrm{La}, \mathrm{Pr}, \mathrm{Nd}, \mathrm{Sm}, \mathrm{Eu}$ and $\mathrm{Gd}$ ) magnetoplumbite for advanced thermal barrier coatings, J. Europ. Ceram. Soc., 35, (2015), 1297-1306. https://doi.org/10.1016/j.jeurceramsoc.2014.10.030

144. Y. Sun, H. Wu, X. Chen, C. Deng, D. Wu, X. Cao, W. Li, Degradation of the plasma sprayed $\mathrm{GdMgAl}_{11} \mathrm{O}_{19}$ thermal barrier coating resistant to calcium-magnesiumaluminum-silicate attack at $1350^{\circ} \mathrm{C}$, Corrosion Sci., 169, (2020), 108593. https://doi.org/10.1016/j.corsci.2020.108593

145. M.M. Khorramirad, M.R. Rahimipour, S.M.M. Hadavi, K. Shirvani, High temperature oxidation behavior of Inc-738/NiCrAIY/LaMA thermal barrier coating system, Surf. Coat. Technol. 364, (2019), 70-80. https://doi.org/10.1016/j.surfcoat.2019.02.017

146. N.P. Padture, M. Gell, E.H. Jordan, Thermal barrier coatings for gas-turbine engine, Appl. Sci., 296, (2002), 280-284. https://doi.org/10.1126/science.1068609

147. J. Sun, J. Wang, H. Zhang, J. Yuan, S. Dong, J. Jiang, L. Deng, X. Zhou, X. Cao, Preparation, structure, mechanical properties and thermal cycling behavior of porous LaMgAl $_{11} \mathrm{O}_{19}$ coating, J. Alloys Comp., 750, (2018), 1007-1016. https://doi.org/10.1016/j.jallcom.2018.04.097

148. J. Sun, J. Wang, X. Zhou, S. Dong, L. Deng, J. Jiang, X. Cao, Microstructure and thermal cycling behavior of plasma-sprayed LaMgAl ${ }_{11} \mathrm{O}_{19}$ coatings, Ceram. Int. 44, (2018), 5572 5580. https://doi.org/10.1016/j.ceramint.2017.12.202 
149. S. Tsukada, S. Kuroda, M. Nishijima, H. Araki, A. Yumoto, M. Watanabe, Effects of amorphous phase on hot corrosion behavior of plasma-sprayed $\mathrm{LaMgAl}_{11} \mathrm{O}_{19}$ coating, $\begin{array}{llll}\text { Surf. } & \text { Coat. } & \text { 363, }\end{array}$ https://doi.org/10.1016/j.surfcoat.2019.01.097

150. J. Zeng, J. Sun, P. Liang, X. Yang, S. Dong, J. Jiang, L. Deng, X. Zhou, X. Cao, Heat-treated lanthanum magnesium hexaaluminate coatings exposed to molten calciummagnesium-alumino-silicate, Ceram. Inter., 45, (2019), 11723-11733. https://doi.org/10.1016/j.ceramint.2019.03.048

151. S.M. Naga, H.F. El-Maghraby, M. Awaad, F. Kern, R. Gadow, A.M. Hassan, Preparation and characterization of tough cerium hexaaluminate bodies, Mater. Lett., 254, (2019), 402-406. https://doi.org/10.1016/j.matlet.2019.07.116

152. S.M. Naga, M. Elshaer, M. Awaad, A.A. Amer, Strontium hexaaluminate/ZTA composites: Preparation and characterization, Mater. Chem. Phys., 232, (2019), 23-27. https://doi.org/10.1016/j.matchemphys.2019.04.055

153. J.J. Torrez-Herrera, E.G. Fuentes-Ordoñez, S.A. Korili, A. Gil, Evidence for the synthesis of La-hexaaluminate from aluminum-contaning saline slag wastes: correction of structural defects and phase purification at low temperature, Powder Technol., 377, (2021), 80-88. https://doi.org/10.1016/j.powtec.2020.08.087 


\section{Captions}

Figure 1. The structure of Ba-hexaaluminate: (a) $\beta-\mathrm{Al}_{2} \mathrm{O}_{3}$ and (b) MP. Numbers in parentheses refer to the different $\mathrm{Al}$ sites. $\mathrm{Al}(1)$ : octahedral site; $\mathrm{Al}(2)$ : tetrahedral site; $\mathrm{Al}(3)$ in $\beta-\mathrm{Al}_{2} \mathrm{O}_{3}$ : tetrahedral site; $\mathrm{Al}(3)$ in $\mathrm{MP}$ : octahedral site; $\mathrm{Al}(4)$ : octahedral site; $\mathrm{Al}(5)$ in $\beta$ $\mathrm{Al}_{2} \mathrm{O}_{3}$ : tetrahedral site; $\mathrm{Al}(5)$ in MP: trigonal bipyramid site. (Reproduced with permission from Ref. 12).

Figure 2. Effect of charge and radius on hexaaluminate structure (Reproduced with permission from Ref. 17).

Figure 3. Proportion of $\beta-\mathrm{Al}_{2} \mathrm{O}_{3}$ and $\mathrm{MP}$ phases and the $\mathrm{Fe} / \mathrm{Ba}$ ratios in both phase compositions as a function of $x$ in $\mathrm{BaFe}_{x} \mathrm{Al}_{12-\mathrm{x}} \mathrm{O}_{19}(\mathrm{x}=1-12)$ samples (Reproduced with permission from Ref. 19).

Figure 4. Procedure for synthesizing fibrous Ba-hexaaluminate (Reproduced with permission from Ref. 34).

Figure 5. Schematic image of fracture surface of quadruple-layered sample of $\mathrm{BaMnAl}_{11} \mathrm{O}_{19}$ ${ }_{\delta} / \mathrm{Ba}_{0.75} \mathrm{Al}_{11} \mathrm{O}_{17.25} / \mathrm{Al}_{6} \mathrm{Si}_{2} \mathrm{O}_{13} / \alpha-\mathrm{SiC}$ after heat treatment at $1400{ }^{\circ} \mathrm{C}$ for $5 \mathrm{~h}$ in air (Reproduced with permission from Ref. 3).

Figure 6. XRD patterns of $\mathrm{LaMnAl}_{11} \mathrm{O}_{19}$ before and after calcination: $(1, \mathrm{a})$ xerogel, $(2, \mathrm{~b})$ aerogel, $(3, \mathrm{c}) \mathrm{LaMnAl}_{11} \mathrm{O}_{19}(\mathrm{CD}),(4, \mathrm{~d}) \mathrm{LaMnAl}_{11} \mathrm{O}_{19}$ (SCD) (Reproduced with permission from Ref. 47).

Figure 7. Various steps in the synthesis of $\mathrm{LaFeAl}_{11} \mathrm{O}_{19}$ using co-precipitation and carbontemplating methods (Reproduced with permission from Ref. 67).

Figure 8. Proposed mechanism for oxygen transfer between palladium and manganese in the supports (Reproduced with permission from Ref. 98). 
Figure 9. Methane conversion versus temperature over the hexaaluminate catalysts (Reproduced with permission from Ref. 80).

Figure 10. Proposed mechanism for the methane combustion on $\mathrm{Mn}_{3} \mathrm{O}_{4} /$ hexaaluminate catalyst (Reproduced with permission from Ref. 102).

Figure 11. Methane conversion as a function of temperature over $1.14 \mathrm{Pd}_{2.8} \mathrm{Pt} / 3 \mathrm{DOM} \mathrm{LMAO}$ at $\mathrm{SV}=$ (a) $20,000 \mathrm{~mL} /(\mathrm{g} \mathrm{h})$, (b) $40,000 \mathrm{~mL} /(\mathrm{g} \mathrm{h})$, and (c) $80,000 \mathrm{~mL} /(\mathrm{g} \mathrm{h})$. Reactant composition: 1.5 vol\% $\mathrm{CH}_{4}+98.5$ vol\% air. (Reproduced with permission from Ref. 72 ).

Figure 12. Dry reforming of methane over an Ni aluminate catalyst at $1123 \mathrm{~K}$ and $1.0 \mathrm{MPa}$ $\mathrm{CH}_{4}, \bullet \mathrm{CO}_{2}, \triangleleft \mathrm{CO}, \Delta \mathrm{H}_{2}, \square \mathrm{H}_{2} \mathrm{O}$ ) (Reproduced with permission from Ref. 68).

Figure 13. Steady-state $\mathrm{N}_{2} \mathrm{O}$ conversion vs. temperature (Reproduced with permission from Ref. 123).

Figure 14. The stabilization mechanism and crystallographic sites of $\mathrm{Ru}$ in $\mathrm{B}_{1}-\mathrm{Al}_{2} \mathrm{O}_{3}$ type $\mathrm{Fe}-$ promoted barium hexaaluminates and the effect on the performance for $\mathrm{N}_{2} \mathrm{O}$ decomposition (Reproduced with permission from Ref. 129).

Figure 15. Proposed mechanism for the $\mathrm{H}_{2} \mathrm{~S}$ decomposition on hexaaluminate catalysts (Reproduced with permission from Ref. 134).

Figure 16. Cross-section SEM image of powdered LaMgAl ${ }_{11} \mathrm{O}_{19} /$ graphite mixtures (a) and a magnification (b) (Reproduced with permission from Ref. 147).

Figure 17. Schematic diagram of proposed calcium-magnesium-alumino-silicate (CMAS) corrosion mechanisms for: (a) as-sprayed hexaaluminate (LMA) coating, (b) isothermally heat-treated LMA coating, (c) as-sprayed LMA coating after CMAS attack, and (d) isothermally heat-treated LMA coating after CMAS attack. (Reproduced with permission from Ref. 150).

Table 1. Strategy synthesis methods and specific surface areas.

Table 2. Catalytic performance by hexaaluminates and reaction conditions. 
(a)

(b)

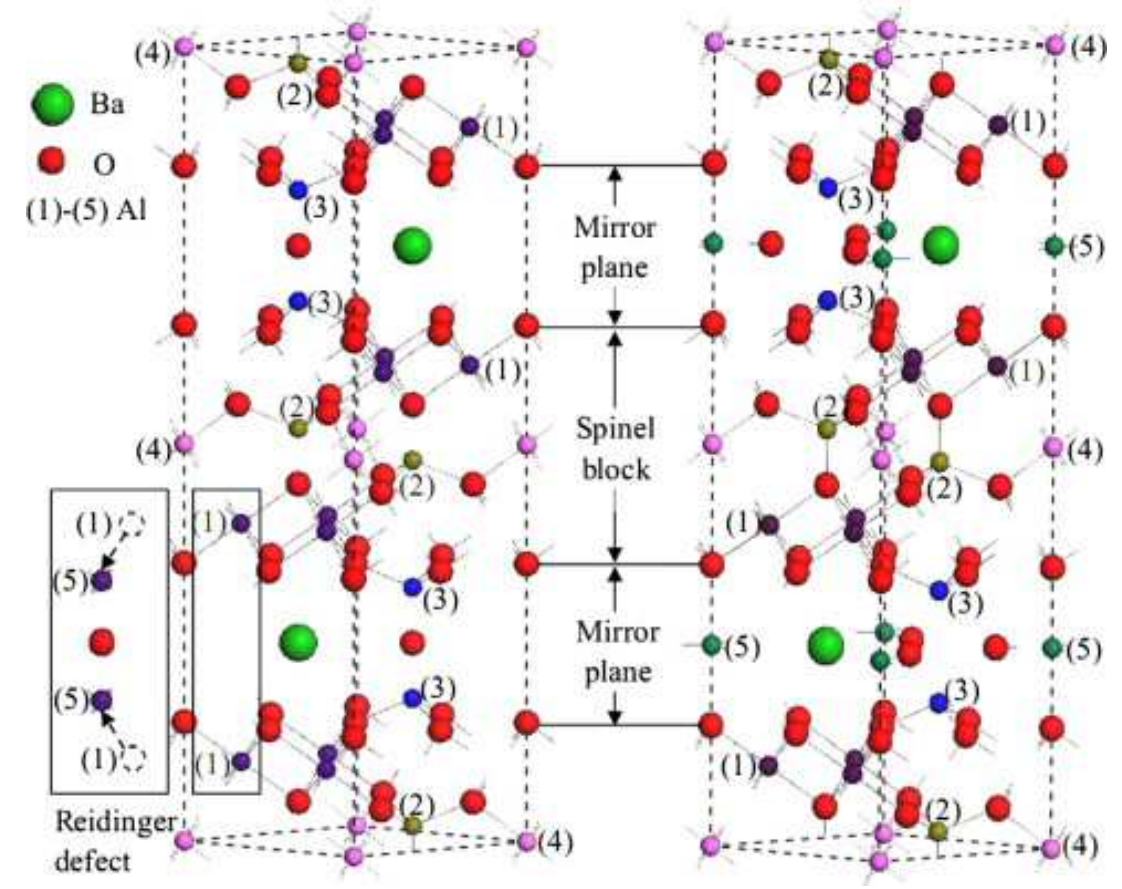

Figure 1. The structure of Ba-hexaaluminate: (a) $\beta-\mathrm{Al}_{2} \mathrm{O}_{3}$ and (b) MP. Numbers in parentheses refer to the different $\mathrm{Al}$ sites. $\mathrm{Al}(1)$ : octahedral site; $\mathrm{Al}(2)$ : tetrahedral site; $\mathrm{Al}(3)$ in $\beta_{-} \mathrm{Al}_{2} \mathrm{O}_{3}$ : tetrahedral site; $\mathrm{Al}(3)$ in $\mathrm{MP}$ : octahedral site; $\mathrm{Al}(4)$ : octahedral site; $\mathrm{Al}(5)$ in $\beta$ $\mathrm{Al}_{2} \mathrm{O}_{3}$ : tetrahedral site; $\mathrm{Al}(5)$ in MP: trigonal bipyramid site. (Reproduced with permission from Ref. 12). 


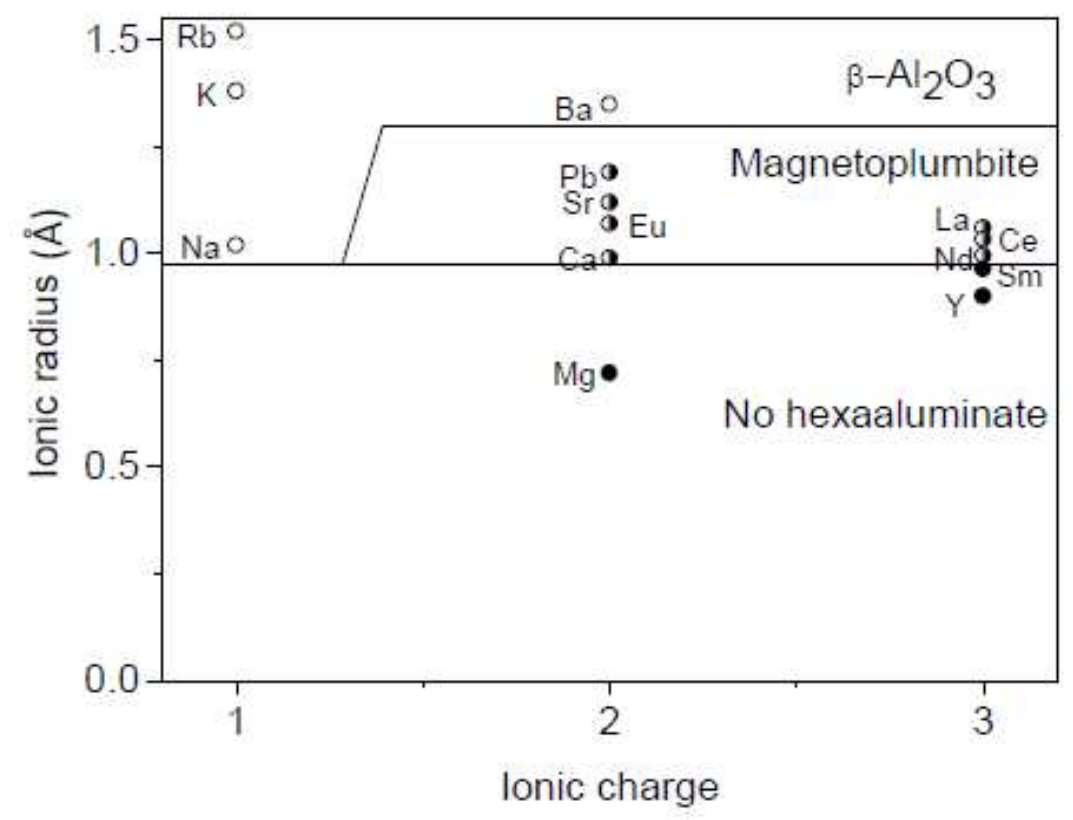

Figure 2. Effect of charge and radius on hexaaluminate structure (Reproduced with permission from Ref. 17). 


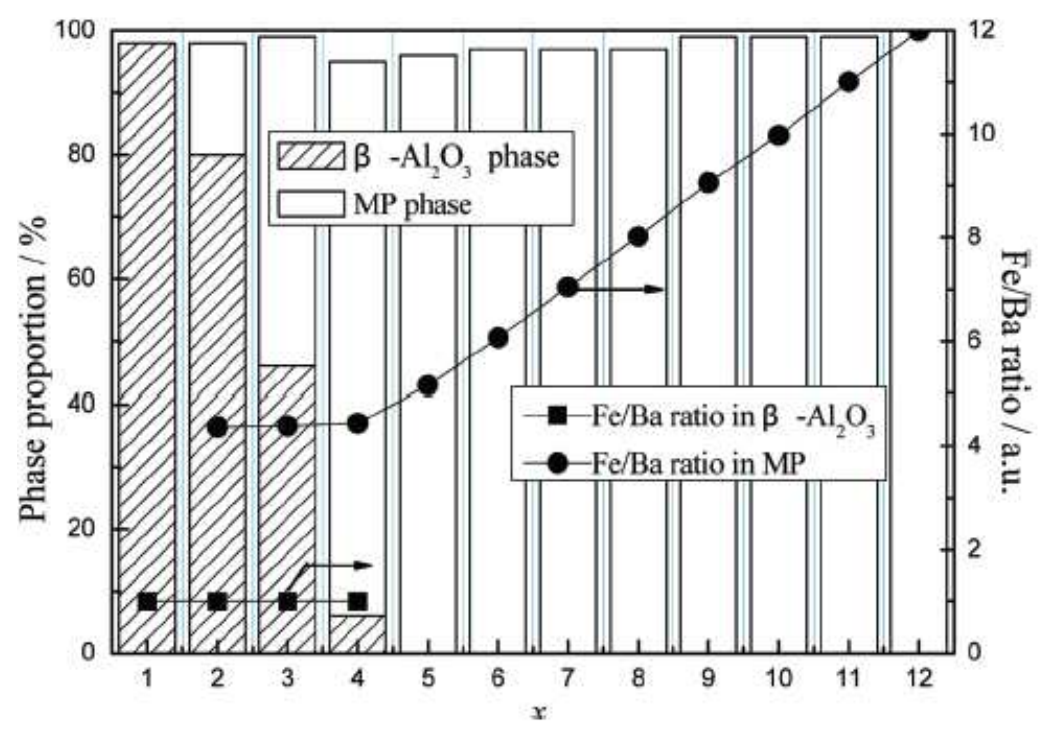

Figure 3. Proportion of $\beta-\mathrm{Al}_{2} \mathrm{O}_{3}$ and $\mathrm{MP}$ phases and the $\mathrm{Fe} / \mathrm{Ba}$ ratios in both phase compositions as a function of $x$ in $\mathrm{BaFe}_{x} \mathrm{Al}_{12-\mathrm{x}} \mathrm{O}_{19}(\mathrm{x}=1-12)$ samples (Reproduced with permission from Ref. 19). 

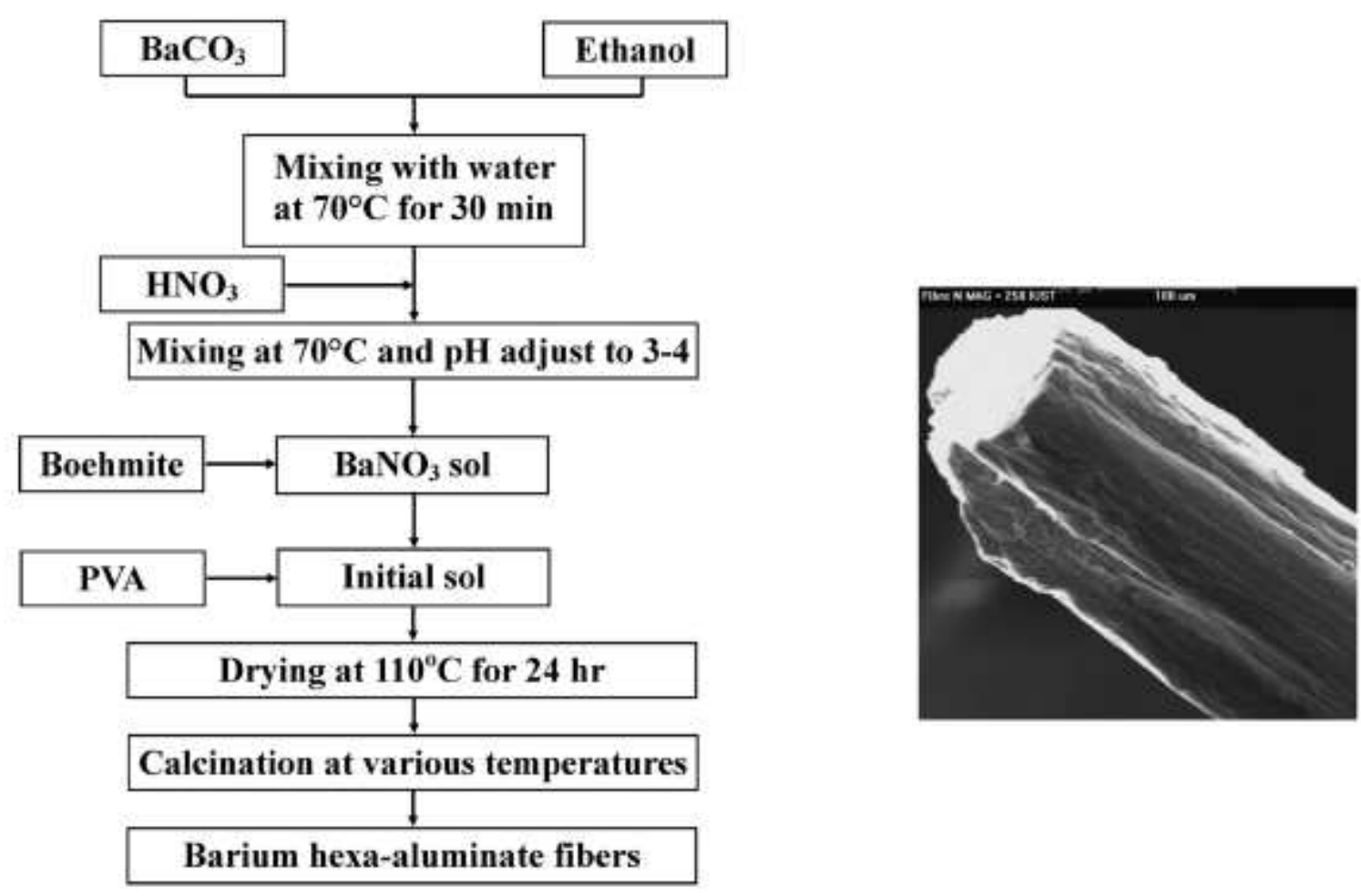

Figure 4. Procedure for synthesizing fibrous Ba-hexaaluminate (Reproduced with permission from Ref. 34). 


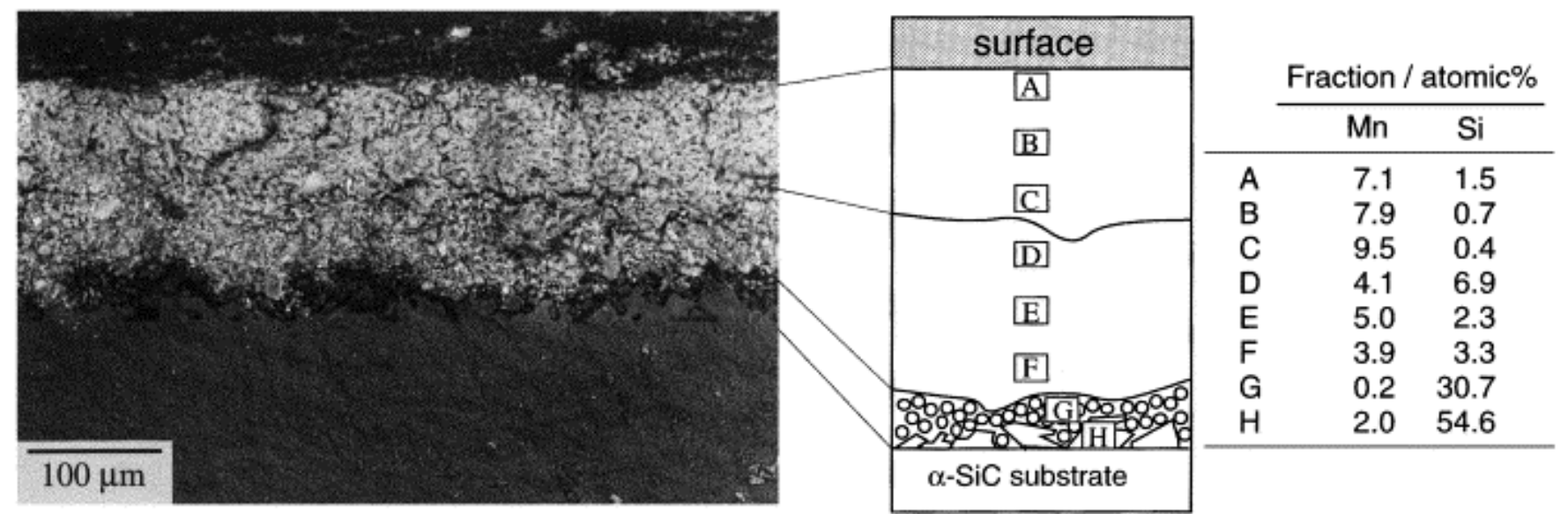

Figure 5. Schematic image of fracture surface of quadruple-layered sample of $\mathrm{BaMnAl}_{11} \mathrm{O}_{19}$ ${ }_{\delta} / \mathrm{Ba}_{0.75} \mathrm{Al}_{11} \mathrm{O}_{17.25} / \mathrm{Al}_{6} \mathrm{Si}_{2} \mathrm{O}_{13} / \alpha$-SiC after heat treatment at $1400{ }^{\circ} \mathrm{C}$ for $5 \mathrm{~h}$ in air (Reproduced with permission from Ref. 3). 


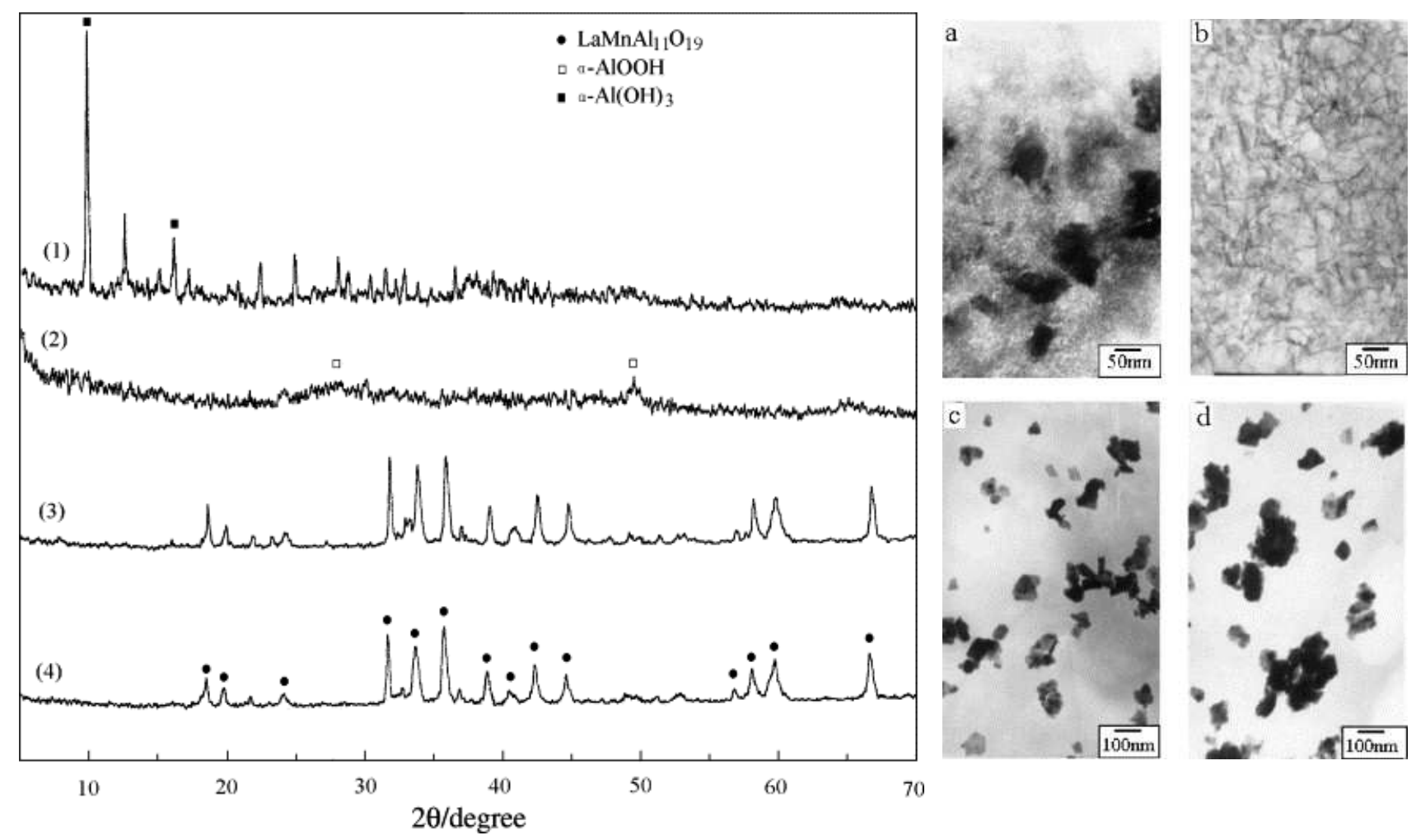

Figure 6. XRD patterns of $\mathrm{LaMnAl}_{11} \mathrm{O}_{19}$ before and after calcination: $(1, \mathrm{a})$ xerogel, $(2, \mathrm{~b})$ aerogel, $(3, \mathrm{c}) \mathrm{LaMnAl}_{11} \mathrm{O}_{19}(\mathrm{CD}),(4, \mathrm{~d}) \mathrm{LaMnAl}_{11} \mathrm{O}_{19}$ (SCD) (Reproduced with permission from Ref. 47). 


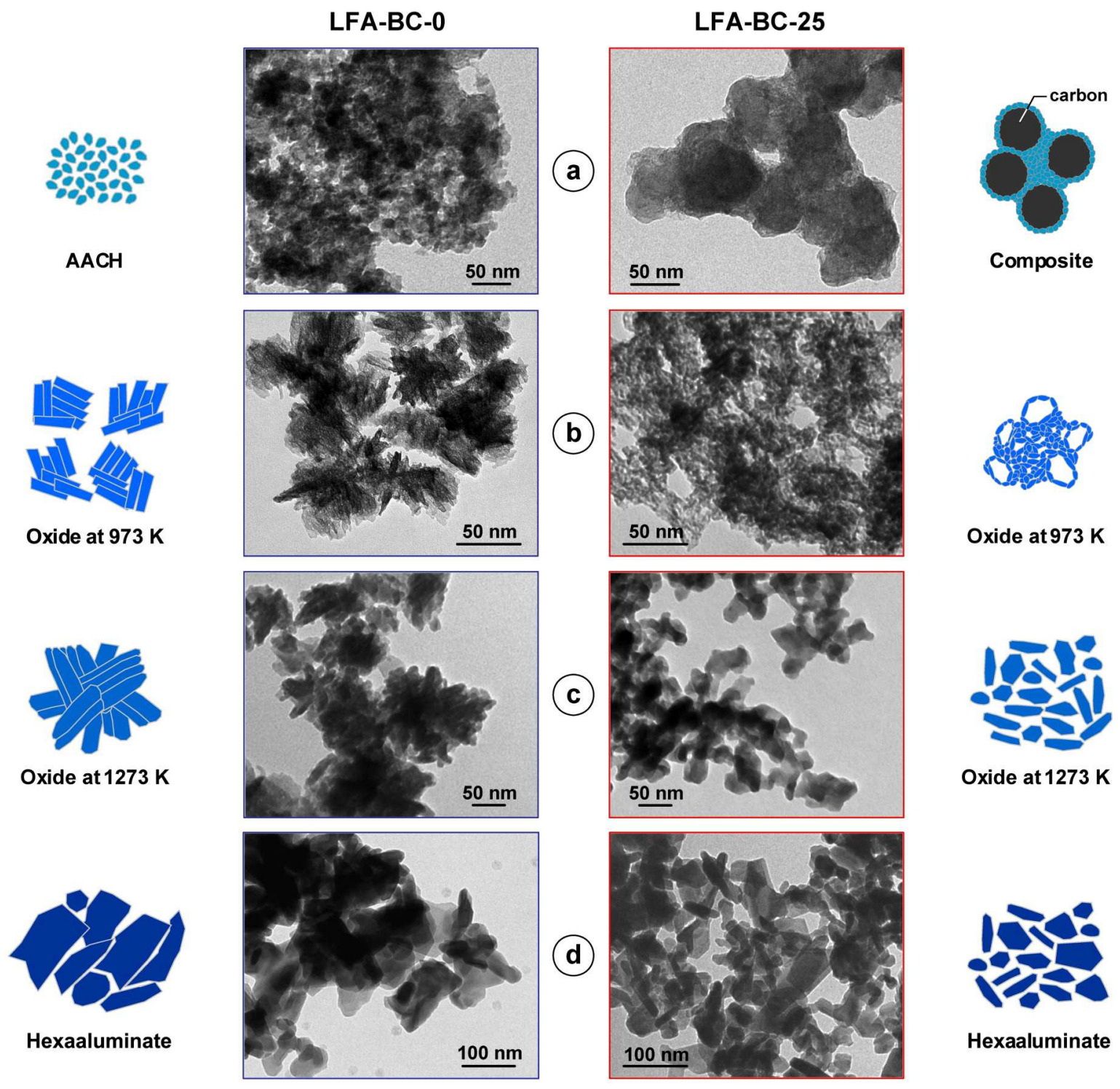

Figure 7. Various steps in the synthesis of $\mathrm{LaFeAl}_{11} \mathrm{O}_{19}$ using co-precipitation and carbontemplating methods (Reproduced with permission from Ref. 67). 


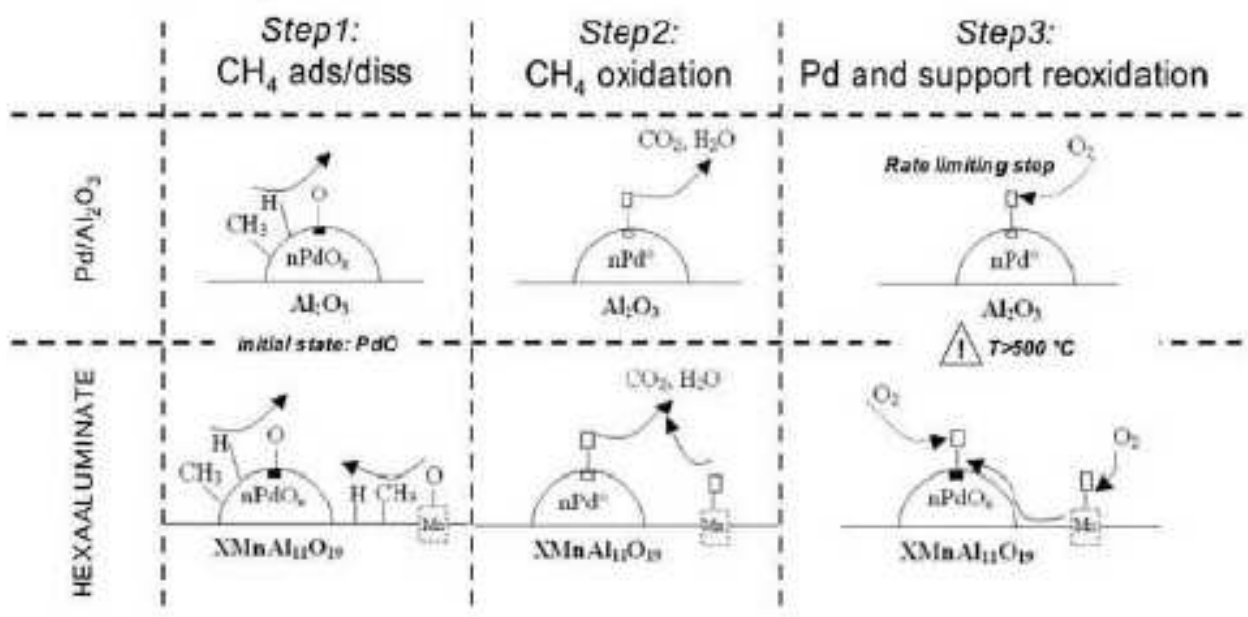

Figure 8. Proposed mechanism for oxygen transfer between palladium and manganese in the supports (Reproduced with permission from Ref. 98). 


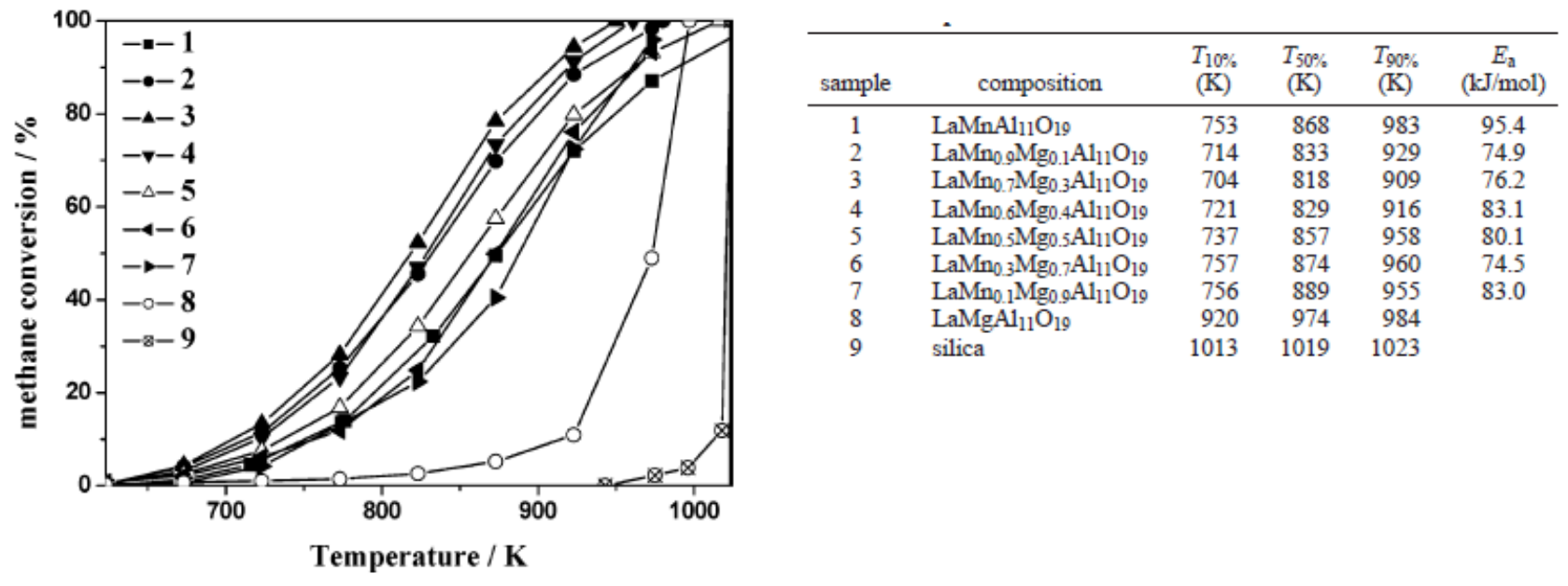

Figure 9. Methane conversion versus temperature over the hexaaluminate catalysts (Reproduced with permission from Ref. 80). 


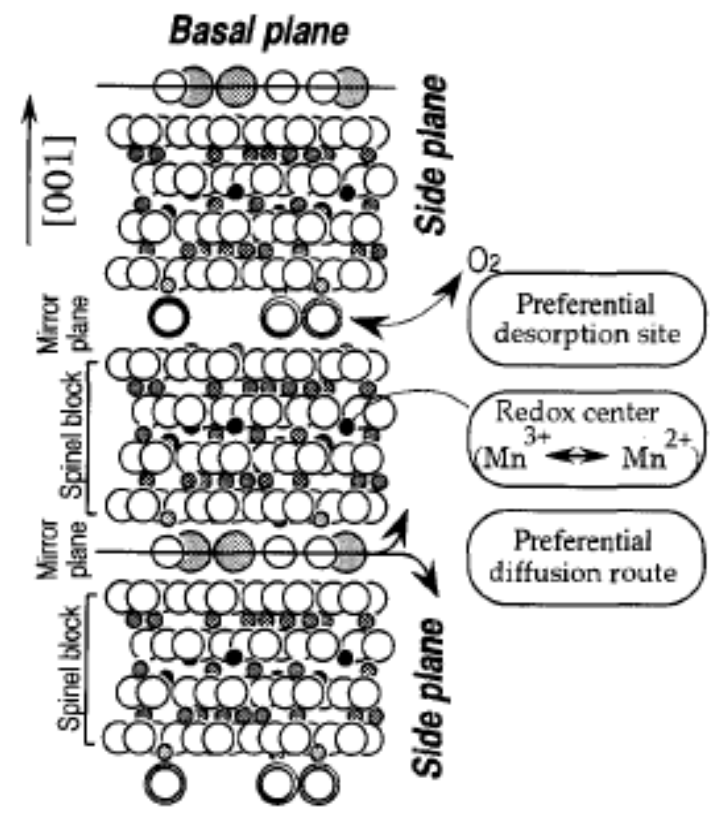

Figure 10. Proposed mechanism for the methane combustion on $\mathrm{Mn}_{3} \mathrm{O}_{4} /$ hexaaluminate catalyst (Reproduced with permission from Ref. 102). 


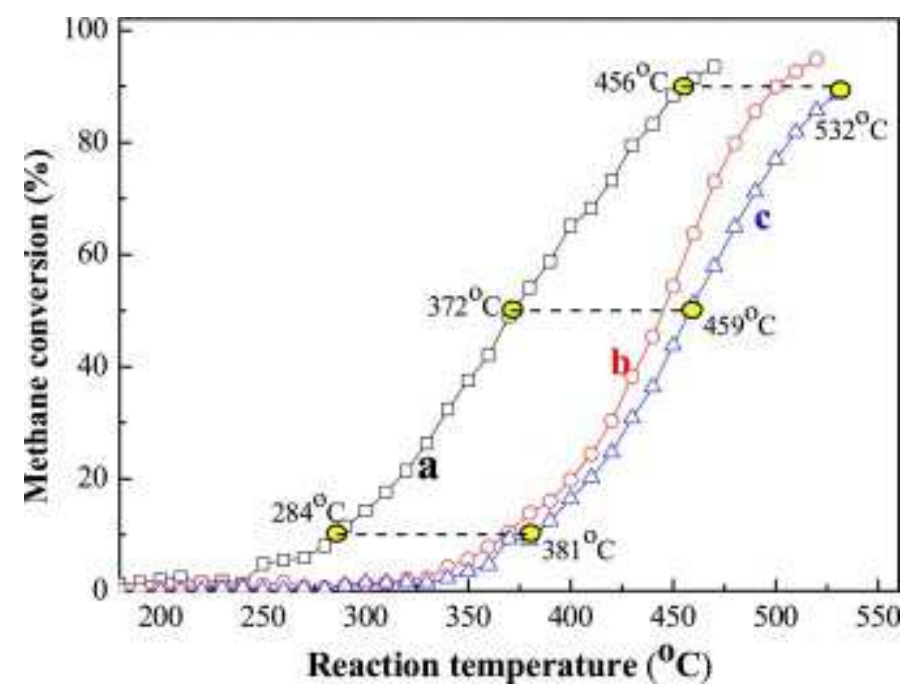

Figure 11. Methane conversion as a function of temperature over $1.14 \mathrm{Pd}_{2.8} \mathrm{Pt} / 3 \mathrm{DOM} \mathrm{LMAO}$ at $\mathrm{SV}=$ (a) $20,000 \mathrm{~mL} /(\mathrm{g} \mathrm{h})$, (b) $40,000 \mathrm{~mL} /(\mathrm{g} \mathrm{h})$, and (c) $80,000 \mathrm{~mL} /(\mathrm{g} \mathrm{h})$. Reactant composition: 1.5 vol\% $\mathrm{CH}_{4}+98.5$ vol\% air. (Reproduced with permission from Ref. 72 ). 


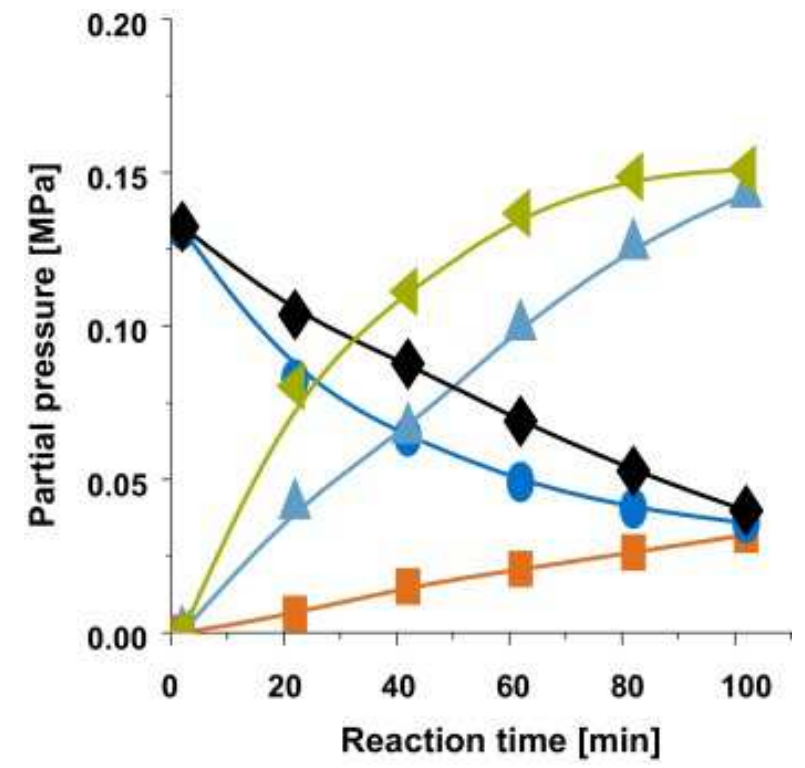

Figure 12. Dry reforming of methane over an $\mathrm{Ni}$ aluminate catalyst at $1123 \mathrm{~K}$ and $1.0 \mathrm{MPa}$ ( $\mathrm{CH}_{4}, \bullet \mathrm{CO}_{2}, \triangleleft \mathrm{CO}, \Delta \mathrm{H}_{2}, \square \mathrm{H}_{2} \mathrm{O}$ ) (Reproduced with permission from Ref. 68). 

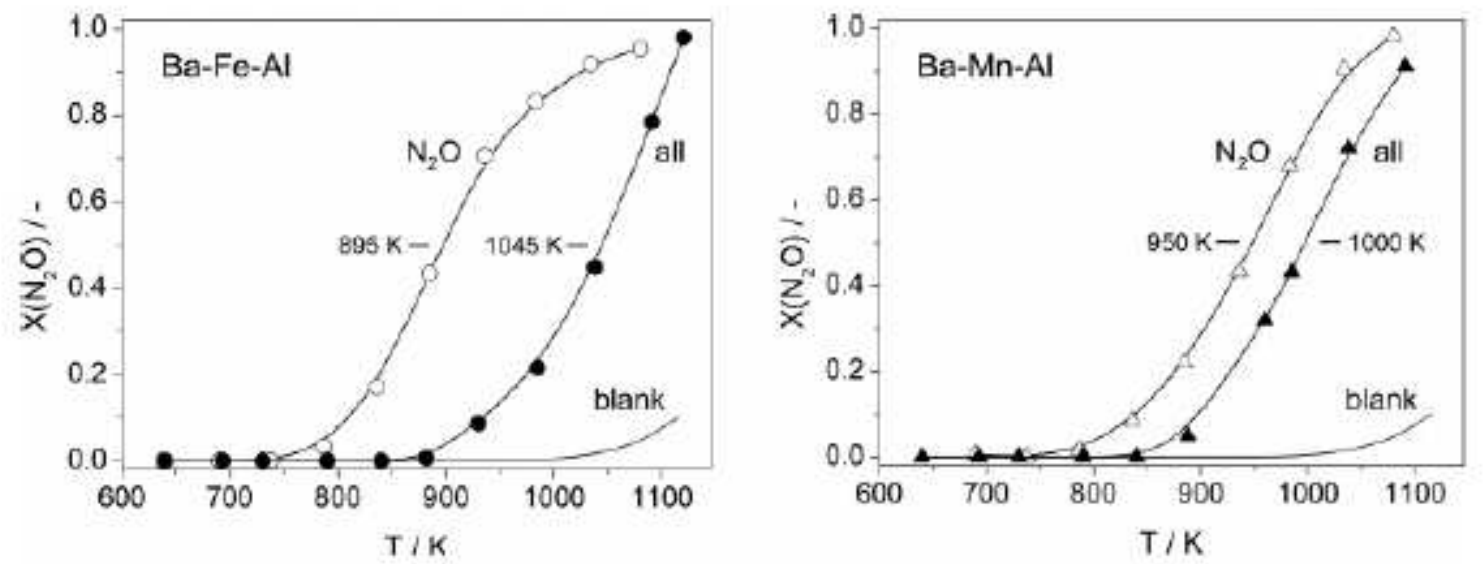

Figure 13. Steady-state $\mathrm{N}_{2} \mathrm{O}$ conversion vs. temperature (Reproduced with permission from Ref. 123). 


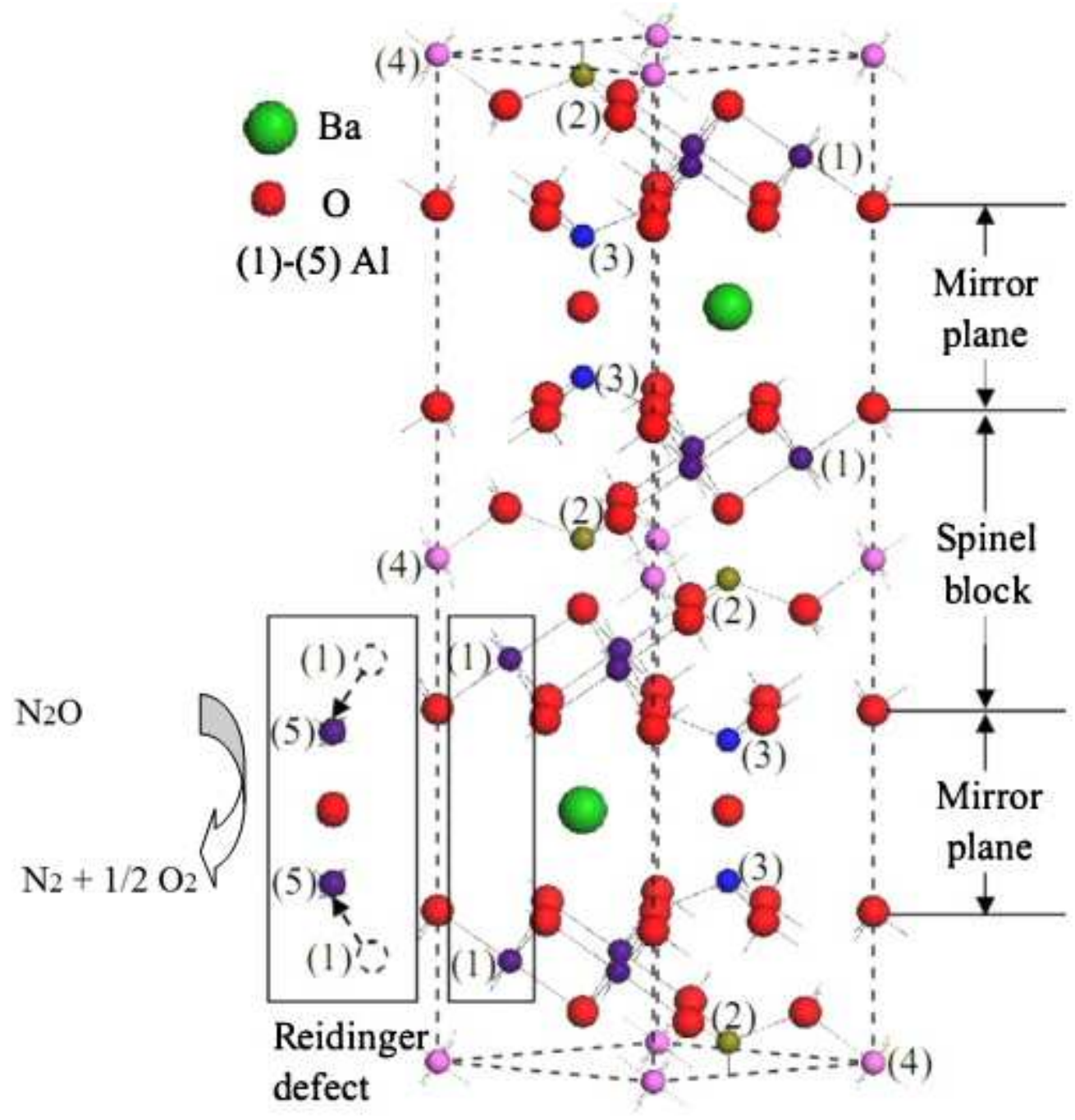

Figure 14. The stabilization mechanism and crystallographic sites of $\mathrm{Ru}$ in $\mathrm{\beta}_{1}-\mathrm{Al}_{2} \mathrm{O}_{3}$ type $\mathrm{Fe}-$ promoted barium hexaaluminates and the effect on the performance for $\mathrm{N}_{2} \mathrm{O}$ decomposition (Reproduced with permission from Ref. 129). 


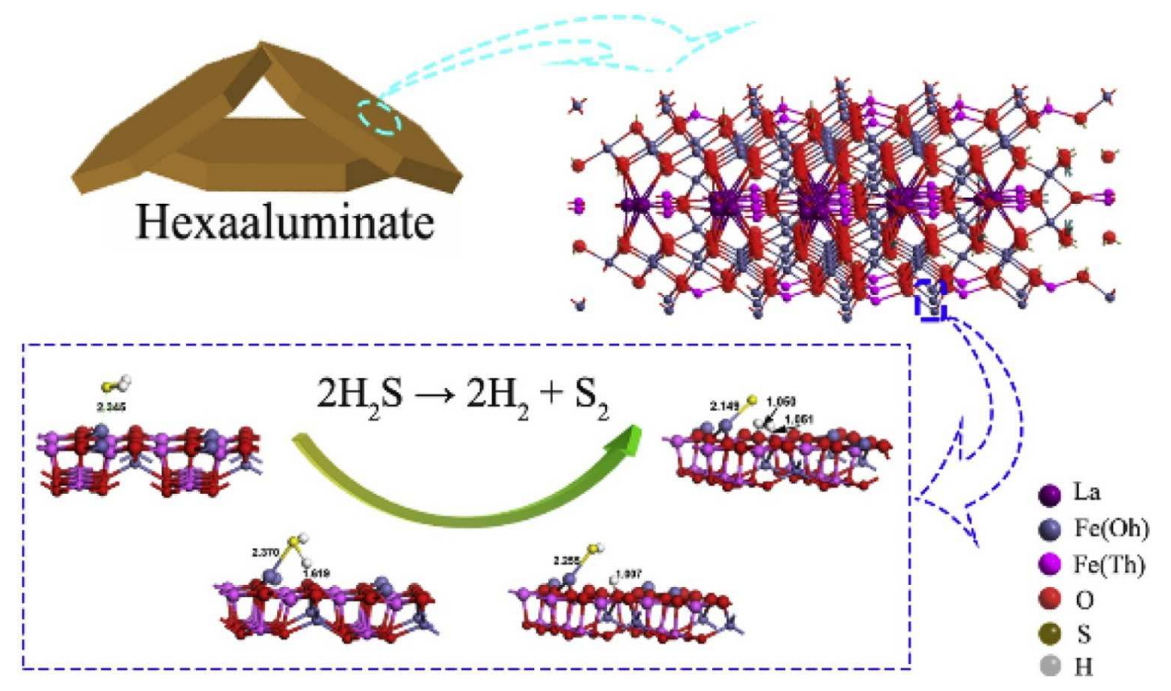

Figure 15. Proposed mechanism for the $\mathrm{H}_{2} \mathrm{~S}$ decomposition on hexaaluminate catalysts (Reproduced with permission from Ref. 134). 

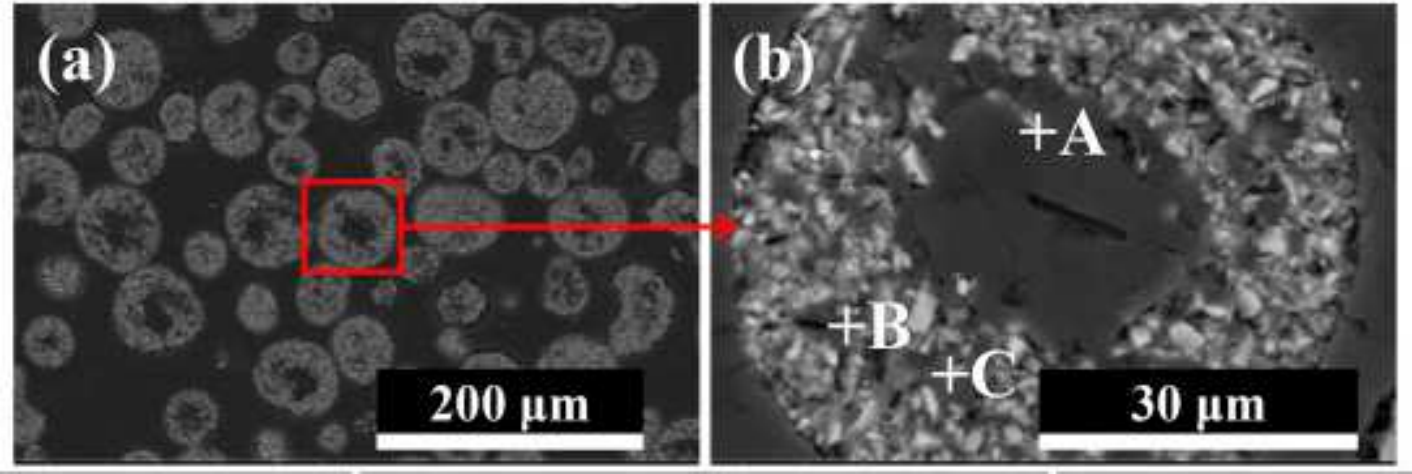

Figure 16. Cross-section SEM image of powdered $\mathrm{LaMgAl}_{11} \mathrm{O}_{19} /$ graphite mixtures (a) and a magnification (b) (Reproduced with permission from Ref. 147). 


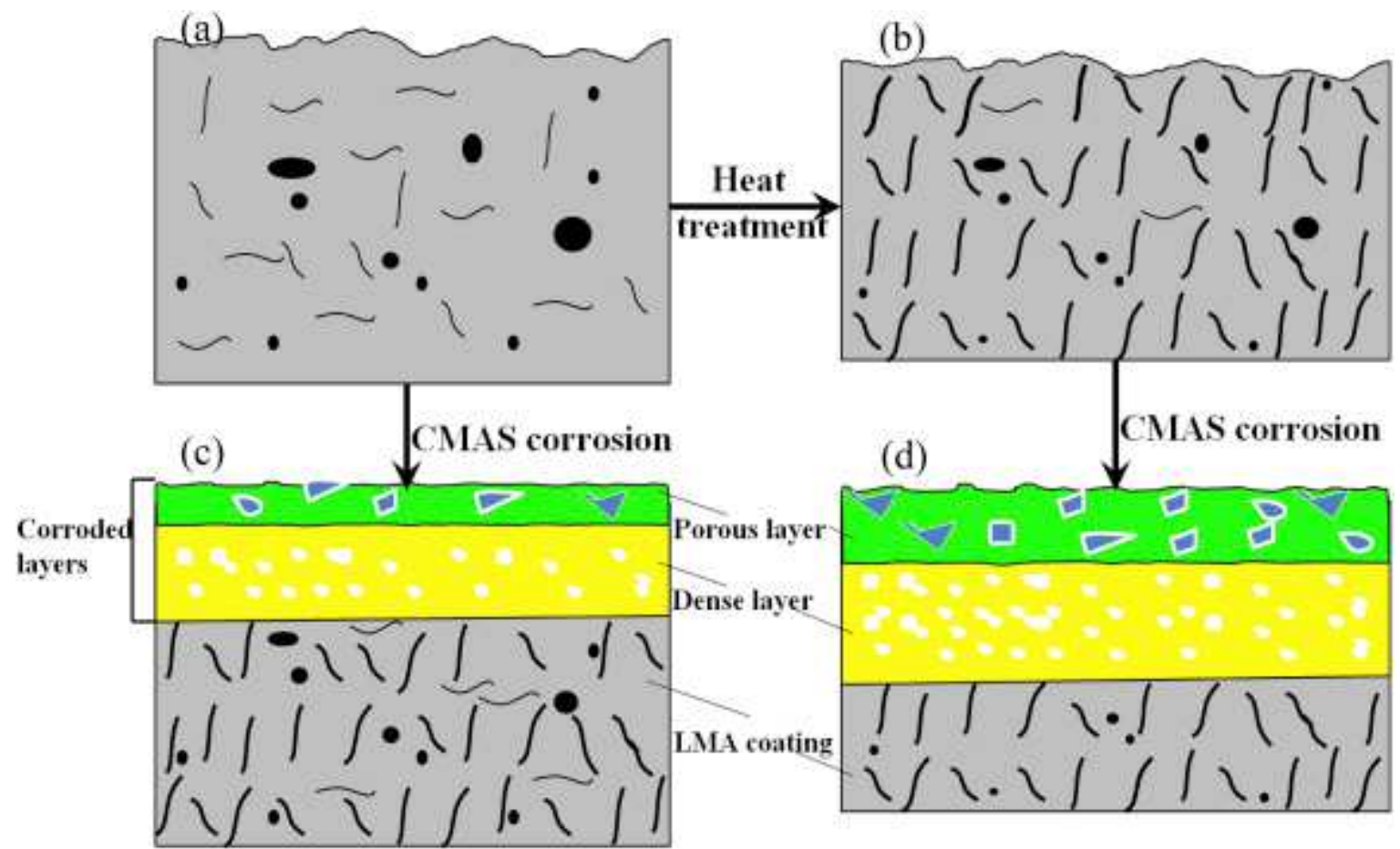

- Globular pore \Vertical crack 10 Porous interaction layer including irregular pores

Horizontal crack $\square$ LMA coating $\square$ Dense interaction layer including calcium lanthanum silicate

Figure 17. Schematic diagram of proposed calcium-magnesium-alumino-silicate (CMAS) corrosion mechanisms for: (a) as-sprayed hexaaluminate (LMA) coating, (b) isothermally heat-treated LMA coating, (c) as-sprayed LMA coating after CMAS attack, and (d) isothermally heat-treated LMA coating after CMAS attack. (Reproduced with permission from Ref. 150). 
Table 1. Strategy synthesis methods and specific surface areas.

\begin{tabular}{|c|c|c|c|c|c|c|c|}
\hline & & & \multicolumn{3}{|c|}{ Calcination conditions } & \multicolumn{2}{|l|}{ Surface area } \\
\hline HA type & Method & Raw materials & $\mathrm{T}\left({ }^{\circ} \mathrm{C}\right)$ & $t(h)$ & Atmosphere & $\mathrm{S}_{\mathrm{BET}}\left(\mathrm{m}^{2} / \mathrm{g}\right)$ & Ref \\
\hline $\mathrm{Ba}-\mathrm{HA}$ & SSR & $\mathrm{BaCO}_{3}, \gamma-\mathrm{Al}_{2} \mathrm{O}_{3}$ & 1450 & 5 & Air & 6 & [11] \\
\hline $\mathrm{Ba}-\mathrm{HA}$ & SSR & $\mathrm{BaCO}_{3}, \alpha-\mathrm{Al}_{2} \mathrm{O}_{3}$ & 1500 & 2 & Air & 10 & [23] \\
\hline $\mathrm{Ba}-\mathrm{HA}$ & \multirow{3}{*}{$\begin{array}{c}\text { ARS and } \\
\text { LEBM }\end{array}$} & $\mathrm{BaO}, \mathrm{Al}_{2} \mathrm{O}_{3}$ & \multirow{3}{*}{1500} & \multirow{3}{*}{5} & \multirow{3}{*}{ Air } & 100 & \multirow{3}{*}{ [26] } \\
\hline Ba-Co-HA & & $\mathrm{BaO}, \mathrm{CoO}, \mathrm{Al}_{2} \mathrm{O}_{3}$ & & & & 79 & \\
\hline Ba-Mn-Pd-HA & & $\mathrm{BaO}, \mathrm{MnO}, \mathrm{PdO}, \mathrm{Al}_{2} \mathrm{O}_{3}$ & & & & 77 & \\
\hline Ba-HA & SG & $\mathrm{Ba}\left(\mathrm{OC}_{3} \mathrm{H}_{7}\right)_{2}, \mathrm{Al}\left(\mathrm{OC}_{3} \mathrm{H}_{7}\right)_{3}$ & 1300 & 2 & Air & 15 & {$[11,28-30]$} \\
\hline $\mathrm{Ba}-\mathrm{Cu}-\mathrm{HA}$ & SG & $\mathrm{Ba}^{+}, \mathrm{Al}\left(\mathrm{OC}_{3} \mathrm{H}_{7}\right)_{3}$ & 1200 & 24 & Oxygen & 11 & [33] \\
\hline $\begin{array}{l}\text { Ba-HA, Ba-Co-HA, Ba-Mn-HA, Ba-Mn- } \\
\text { Co-HA }\end{array}$ & SG-SD & $\begin{array}{c}\mathrm{Mn}\left(\mathrm{NO}_{3}\right)_{2}, \mathrm{Co}\left(\mathrm{NO}_{3}\right)_{3}, \mathrm{Ba}\left(\mathrm{OC}_{2} \mathrm{H}_{5}\right)_{2}, \mathrm{Ba}\left(\mathrm{OC}_{4} \mathrm{H}_{9}\right)_{3} \\
\mathrm{CH}_{3} \mathrm{COCH}_{2} \mathrm{COOC}_{2} \mathrm{H}_{5}\end{array}$ & 1200 & 5 & Air & $14-15$ & [39] \\
\hline La-Mn-HA & SM & $\begin{array}{c}\mathrm{Al}_{2} \mathrm{O}_{3}, \mathrm{La}\left(\mathrm{CH}_{3} \mathrm{COO}\right)_{2} \mathrm{x} \cdot \mathrm{H}_{2} \mathrm{O}, \mathrm{Mn}\left(\mathrm{CH}_{3} \mathrm{COO}\right)_{2} \cdot 4 \mathrm{H}_{2} \mathrm{O}, \mathrm{CTACl}, \mathrm{SE}- \\
30 \text {, Triton } \mathrm{X}-100\end{array}$ & 1200 & 6 & Air & 42 & [41] \\
\hline Ba-HA & $\mathrm{CP}$ & $\mathrm{Ba}\left(\mathrm{NO}_{3}\right)_{2}, \mathrm{Mn}\left(\mathrm{NO}_{3}\right)_{2}, \mathrm{Al}\left(\mathrm{NO}_{3}\right)_{3} \cdot 9 \mathrm{H}_{2} \mathrm{O},\left(\mathrm{NH}_{4}\right)_{2} \mathrm{CO}_{3}$ & 1400 & 10 & Air & 15 & [43] \\
\hline Sr-La-Mn-HA & $\mathrm{CP}$ & $\mathrm{Sr}\left(\mathrm{NO}_{3}\right)_{2}, \mathrm{La}\left(\mathrm{NO}_{3}\right)_{3} \cdot 6 \mathrm{H}_{2} \mathrm{O}, \mathrm{Mn}\left(\mathrm{NO}_{3}\right)_{2}, \mathrm{Al}\left(\mathrm{NO}_{3}\right)_{3} \cdot 9 \mathrm{H}_{2} \mathrm{O},\left(\mathrm{NH}_{4}\right)_{2} \mathrm{CO}_{3}$ & 1200 & 2 & Air & 51 & [46] \\
\hline La-Mn-HA & CP-SD & $\mathrm{La}\left(\mathrm{NO}_{3}\right)_{3} \cdot 6 \mathrm{H}_{2} \mathrm{O}, \mathrm{Mn}\left(\mathrm{NO}_{3}\right)_{2}, \mathrm{Al}\left(\mathrm{NO}_{3}\right)_{3} \cdot 9 \mathrm{H}_{2} \mathrm{O}, \mathrm{NH}_{4} \mathrm{OH}$ & 1200 & 4 & Air & 28 & [47] \\
\hline $\mathrm{Ba}-\mathrm{HA}$ & RM & $\mathrm{Ba}\left(\mathrm{OC}_{3} \mathrm{H}_{7}\right)_{2}, \mathrm{Al}\left(\mathrm{OC}_{3} \mathrm{H}_{7}\right)_{3}$ & 1300 & 2 & Air & 130 & [48] \\
\hline Ba-HA & RM & $\mathrm{Ba}\left(\mathrm{OC}_{3} \mathrm{H}_{7}\right)_{2}, \mathrm{Al}\left(\mathrm{OC}_{3} \mathrm{H}_{7}\right)_{4}, \mathrm{NH}_{4} \mathrm{OH}$, Triton X-100, N-Hexanol & 1300 & 6 & Air & 90 & [51] \\
\hline
\end{tabular}

HA: Hexaaluminate

SSR: State solid reaction

ARS: Activated reactive synthesis

LEBM: Low energy ball mill

SG: Sol gel

SD: Supercritical Drying

SM: Surfactant madiated

CP: Coprecipitation

RM: Reverse Microemulsion 
Table 2. Catalytic performance by hexaaluminates and reaction conditions.

\begin{tabular}{|c|c|c|c|c|c|c|}
\hline \multirow[t]{2}{*}{ Catalysts } & \multirow{2}{*}{$\begin{array}{l}\text { Surface } \\
\text { area } \\
\left(\mathrm{m}^{2} / \mathrm{g}\right)\end{array}$} & \multicolumn{2}{|c|}{ Reaction conditions } & \multirow[t]{2}{*}{ Reaction type } & \multirow[t]{2}{*}{ Catalytic effect } & \multirow[t]{2}{*}{ References } \\
\hline & & $\mathrm{T}_{10}\left({ }^{\circ} \mathrm{C}\right)$ & $\mathrm{T}_{90}\left({ }^{\circ} \mathrm{C}\right)$ & & & \\
\hline $\begin{array}{c}\mathrm{BaM}_{x} \mathrm{Al}_{12-x} \mathrm{O}_{19-\alpha} ; \\
\text { LaMAl }_{11} \mathrm{O}_{19}(\mathrm{M}: \mathrm{Cr}, \mathrm{Mn}, \mathrm{Fe}, \mathrm{Co}, \mathrm{Ni})\end{array}$ & $\begin{array}{l}11.1- \\
15.7\end{array}$ & $540-810$ & $720-780$ & $\mathrm{CH}_{4}$ Combustion & $\begin{array}{l}\text { Order of reactivity: } \mathrm{Mn}>\mathrm{Fe}>>\mathrm{Co}=\mathrm{Cr}=\mathrm{Ni} \text {. The combustion } \\
\text { performance is mainly determined by the nature of the } \\
\text { transition metal. }\end{array}$ & {$[28,101]$} \\
\hline $\mathrm{BaCuAl}_{11} \mathrm{O}_{18.5}$ & 11 & 510 & 610 & $\mathrm{CH}_{4}$ Combustion & $\begin{array}{l}\text { The introduction of } \mathrm{Cu}^{2+} \text { ions in the Ba-hexaaluminate } \\
\text { structure leads to a fairly active catalyst. }\end{array}$ & {$[37,78]$} \\
\hline $\mathrm{BaMn}_{0.5} \mathrm{Co}_{0.5} \mathrm{Al}_{11} \mathrm{O}_{19}$ & 15.2 & 585 & 740 & $\mathrm{CH}_{4}$ Combustion & $\begin{array}{l}\text { A synergetic effect is reported. The doubly substituted } \\
\text { material, } \mathrm{BaMn}_{0.5} \mathrm{Co}_{0.5} \mathrm{Al}_{11} \mathrm{O}_{19-\alpha} \text {, had a higher reaction rate than } \\
\mathrm{BaMnAl}_{11} \mathrm{O}_{19-\alpha} \text { and } \mathrm{BaCoAl}_{11} \mathrm{O}_{19-\alpha} \text {. }\end{array}$ & [39] \\
\hline $\begin{array}{c}\mathrm{Mn}_{3} \mathrm{O}_{4} / \mathrm{BaMnAl}_{10} \mathrm{O}_{17.25} \\
\left.\left(\mathrm{Mn}_{1-\mathrm{x}} \mathrm{M}_{\mathrm{x}}\right)_{3} \mathrm{O}_{4}, \mathrm{M}=\mathrm{Fe}, \mathrm{Co}, \mathrm{Ni}\right)\end{array}$ & 20 & $360-418$ & $530-580$ & $\mathrm{CH}_{4}$ Combustion & $\begin{array}{l}\text { It was revealed that the air oxidation derived composites } \\
\text { showed the excellent specific activities superior to those of the } \\
\text { corresponding } \mathrm{Mn}_{3} \mathrm{O}_{4} / \text { hexaaluminates prepared from the } \\
\text { conventional impregnation method. }\end{array}$ & [102] \\
\hline Sro.8La0.2XAl ${ }_{11} \mathrm{O}_{19}, \mathrm{X}=\mathrm{Al}$ and $\mathrm{Mn}$ & $\begin{array}{l}19.7 \\
16.9\end{array}$ & 380,420 & 650,700 & $\mathrm{CH}_{4}$ Combustion & $\begin{array}{l}\text { The authors reported that the catalytic performance initially } \\
\text { increase with the temperature, but decreases at about } 700{ }^{\circ} \mathrm{C} \text {. } \\
\text { This activity drop is related to the dissociation of } \mathrm{PdO} \text { into } \\
\text { metallic } \mathrm{Pd} \text { species, that is observed at low oxygen partial } \\
\text { pressures. This behavior is related to the removal of adsorbed } \\
\text { oxygen species necessary for the catalytic reaction. }\end{array}$ & [31] \\
\hline $\begin{array}{c}\mathrm{BaNi}_{\mathrm{y}} \mathrm{Al}_{12-\mathrm{y}} \mathrm{O}_{19-\delta} \\
(\mathrm{y}=0.3,0.6,0.9,1)\end{array}$ & - & 300 & 850 & $\begin{array}{l}\text { POM (Reforming of } \\
\text { methane to syngas } \\
\text { synthesis) }\end{array}$ & $\begin{array}{l}\text { The catalysts showed high activity and selectivity with a } \mathrm{CH}_{4} \\
\text { conversion of } 92 \% \text { and CO selectivity of } 95 \% \text { at } 850{ }^{\circ} \mathrm{C} \text {. The } \\
\text { catalysts also exhibited an excellent ability to suppress carbon } \\
\text { deposition and loss of active phase, so that they exhibited high } \\
\text { stabilities after } 100 \text { h of reaction. }\end{array}$ & [110] \\
\hline
\end{tabular}




\begin{tabular}{|c|c|c|c|c|}
\hline $\mathrm{BaNiAl}_{11} \mathrm{O}_{19-\alpha}$ & 24 & $250-300$ & 750 & $\begin{array}{l}\text { POM (Reforming of } \\
\text { methane to syngas } \\
\text { synthesis) }\end{array}$ \\
\hline $2-5-10 \% \mathrm{Ni} / \mathrm{BHA}$ & $21-24$ & - & $250-350$ & $\begin{array}{l}\text { CO Methanation } \\
\text { (Reforming of methane } \\
\text { to syngas synthesis) }\end{array}$ \\
\hline $\begin{array}{l}\mathrm{Rh} / \mathrm{BaAl}_{12} \mathrm{O}_{19}-\mathrm{SrAl}_{12} \mathrm{O}_{19}- \\
\mathrm{CaAl}_{12} \mathrm{O}_{19} \text { vs } \mathrm{Rh} / \alpha-\mathrm{Al}_{2} \mathrm{O}_{3}\end{array}$ & $4-15$ & $720-750$ & $1000-1050$ & $\begin{array}{l}\text { POM (Reforming of } \\
\text { methane to syngas } \\
\text { synthesis) }\end{array}$ \\
\hline $\begin{array}{c}\mathrm{Ca}_{1-x \mathrm{LaxNiAl}}{ }_{11} \mathrm{O}_{19-\delta} \\
(\mathrm{x}: 0.1,0.2,0.3,0.5,0.7,0.9,1)\end{array}$ & $1-6$ & $450-500$ & $750-900$ & $\begin{array}{l}\text { DRM (Reforming of } \\
\text { methane to syngas } \\
\text { synthesis) }\end{array}$ \\
\hline $\begin{array}{l}\operatorname{LaNi}_{y} \mathrm{Al}_{12-y} \mathrm{O}_{19-\delta} \\
(\mathrm{y}=0.3,0.6,0.9,1)\end{array}$ & - & 500 & 800 & $\begin{array}{l}\text { DRM (Reforming of } \\
\text { methane to syngas } \\
\text { synthesis) }\end{array}$ \\
\hline
\end{tabular}

The authors found that hexaaluminate calcined at $1400{ }^{\circ} \mathrm{C}$ exhibited a more stable and higher behavior than the first one calcined at $1000{ }^{\circ} \mathrm{C}$. The $\mathrm{BaNiAl}_{11} \mathrm{O}_{19-\alpha}$ catalyst calcined at 1400 ${ }^{\circ} \mathrm{C}$ and reduced to $1000{ }^{\circ} \mathrm{C}$ showed a higher activity than BaNiAl ${ }_{11} \mathrm{O}_{19-\alpha}$ calcined at $1200^{\circ} \mathrm{C}$ and reduced to $800^{\circ} \mathrm{C}$. This behavior is explained by the authors from the presence of a $\mathrm{Ni}$ rich surface and highly dispersed Ni species.

CO is completely converted ( $>99 \%$ ) over $2 \mathrm{Ni} / \mathrm{BHA}$ and $5 \mathrm{Ni} /$ $\mathrm{BHA}$ catalysts at $350^{\circ} \mathrm{C}$. With the increase of NiO loading for the $10 \mathrm{Ni} / \mathrm{BHA}$ catalyst, the maximum peak of $\mathrm{CO}$ conversion $(>99 \%)$ shifts to lower temperature $\left(250^{\circ} \mathrm{C}\right)$ and is maintained in the range $250-400{ }^{\circ} \mathrm{C}$. In contrast, for $\mathrm{Ni} / \mathrm{Al}_{2} \mathrm{O}_{3}$ catalysts, the maximum CO conversion is only 93.5 and $21.7 \%$ obtained over $10 \mathrm{Ni} / \mathrm{Al}_{2} \mathrm{O}_{3}$ and $5 \mathrm{Ni} / \mathrm{Al}_{2} \mathrm{O}_{3}$ at $400-450{ }^{\circ} \mathrm{C}$

The authors compares the results obtained with a commercial 列 $/ \alpha-\mathrm{Al}_{2} \mathrm{O}_{3}$ showing that hexaaluminate catalysts were less stable, active and selective than the commercial catalyst. $\mathrm{Rh} / \alpha-\mathrm{Al}_{2} \mathrm{O}_{3}>\mathrm{Rh} / \mathrm{BaAl}_{12} \mathrm{O}_{19}=\mathrm{SrAl}_{12} \mathrm{O}_{19}=\mathrm{CaAl}_{12} \mathrm{O}_{19}$

The authors indicated that activity increases with the degree of Ni substitution, but also increases the amount of carbon produced.

The authors found that catalytic activity increases with temperature in the range of $500-900{ }^{\circ} \mathrm{C}$ and with the amount of nickel substituted where $\mathrm{LaNiAl}_{11} \mathrm{O}_{19-\delta}>\mathrm{LaNi}_{0.9} \mathrm{Al}_{11.1 \mathrm{O}_{19-\delta}}>$ LaNio.6 $\mathrm{Al}_{11.4 \mathrm{O}_{19-\delta}}>\mathrm{LaNi}_{0.3 \mathrm{Al}} \mathrm{I}_{11.7} \mathrm{O}_{19-\delta}$ 


\begin{tabular}{|c|c|c|c|c|c|c|}
\hline \multirow[b]{2}{*}{$\begin{array}{c}\mathrm{ABAl}_{11} \mathrm{O}_{19} \\
(\mathrm{~A}=\mathrm{La}, \mathrm{Ba} \text { and } \mathrm{B}=\mathrm{Mn}, \mathrm{Fe}, \mathrm{Ni})\end{array}$} & & \multirow[b]{2}{*}{$830-850$} & \multirow[b]{2}{*}{$950-1200$} & \multirow[b]{2}{*}{ Transformation of $\mathrm{N}_{2} \mathrm{O}$} & & \multirow{2}{*}{ [123] } \\
\hline & - & & & & $\begin{array}{l}\text { Fe and } \mathrm{Mn} \text {-containing hexaaluminates showed the highest } \\
\text { activities, whereas Ni-containing catalysts are less active, } \\
\text { compared to unsubstituted hexaaluminate. }\end{array}$ & \\
\hline $\mathrm{BaMnAl}_{11} \mathrm{O}_{19}$ & 15 & $100-150$ & $400-450$ & $\begin{array}{l}\mathrm{NH}_{3} \text { oxidation } \\
\text { (Transformation of } \\
\mathrm{N}_{2} \mathrm{O} \text { ) }\end{array}$ & $\begin{array}{l}\text { The authors show significant amounts of NO that increase with } \\
\text { temperature with a maximum at about } 750^{\circ} \mathrm{C} \text {. From this } \\
\text { temperature the NO concentration decrease related to the } \\
\text { occurrence of a selective non-catalytic reduction process }\end{array}$ & [128] \\
\hline $\begin{array}{l}\mathrm{Balr}_{\times} \mathrm{Fe}_{1-x} \mathrm{Al}_{11} \mathrm{O}_{19} \\
(\mathrm{x}: 0.2,0.5,0.8)\end{array}$ & $10-23$ & $325-350$ & $380-450$ & $\mathrm{~N}_{2} \mathrm{O}$ decomposition & $\begin{array}{l}\text { Here it was found that } \mathrm{Balr}_{x} \mathrm{Fe}_{1-x} \mathrm{Al}_{11} \mathrm{O}_{19} \text { hexaaluminates } \\
\text { exhibited much higher activities and stabilities than } \mathrm{Ir} / \mathrm{Al}_{2} \mathrm{O}_{3-} \\
1200 \text {. Comparing BalrxFe } \\
0.8) \text {, it was found that iridium was the active component in the } \\
\text { decomposition of } \mathrm{N}_{2} \mathrm{O} \text { and the Iridium of the structure was } \\
\text { more active than the large } \mathrm{IrO}_{2} \text { particles. }\end{array}$ & [93] \\
\hline $\begin{array}{l}\operatorname{LaMn}_{\times} \mathrm{Al}_{(12-x)} \mathrm{O}_{19} \\
\mathrm{BaMn}_{\times} \mathrm{Al}_{(12-x)} \mathrm{O}_{19}\end{array}$ & $21-27$ & $500-550$ & $650-700$ & $\mathrm{~N}_{2} \mathrm{O}$ decomposition & $\begin{array}{l}\text { The authors reported that the Ba-hexaaluminate exhibited } \\
\text { higher activity than the La-hexaaluminate at a given } \mathrm{Mn} \\
\text { content that can be related by the presence of active } \mathrm{Mn}^{3+} \\
\text { sites in the octahedral position of the } \mathrm{Mn} \text {-substituted Ba- } \\
\text { hexaaluminate. }\end{array}$ & [28-101] \\
\hline
\end{tabular}

